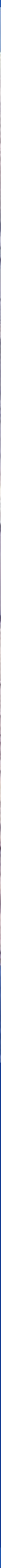





\section{Rural migration in sub-Saharan Africa: Patterns, drivers and relation to structural transformation}

Authors: Sara Mercandalli (eds.), Bruno Losch (eds.), Michael N. Belebema, Jean-François Bélières, Robin Bourgeois, Mulugeta F. Dinbabo, Sandrine Fréguin-Gresh, Clement Mensah, Christopher Nshimbi.

Food and Agriculture Organization of the United Nations Rome, 2019 
Required citation:

Mercandalli S., Losch B. (eds.), Belebema M.N., Bélières J.-F., Bourgeois R., Dinbabo M.F., Fréguin-Gresh S., Mensah C., Nshimbi C.C. 2019. Rural migration in sub-Saharan Africa: Patterns, drivers and relation to structural transformation. Rome, FAO and CIRAD. https://doi.org/10.4060/ca7404en

The designations employed and the presentation of material in this information product do not imply the expression of any opinion whatsoever on the part of the Food and Agriculture Organization of the United Nations (FAO) concerning the legal or development status of any country, territory, city or area or of its authorities, or concerning the delimitation of its frontiers or boundaries. The mention of specific companies or products of manufacturers, whether or not these have been patented, does not imply that these have been endorsed or recommended by FAO in preference to others of a similar nature that are not mentioned.

The views expressed in this information product are those of the author(s) and do not necessarily reflect the views or policies of FAO.

ISBN 978-92-5-132110-2

(c) FAO, 2019

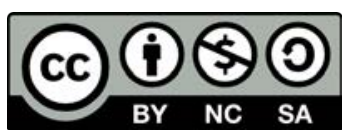

Some rights reserved. This work is made available under the Creative Commons AttributionNonCommercial-ShareAlike 3.0 IGO licence (CC BY-NC-SA 3.0 IGO; https://creativecommons.org/ licenses/by-nc-sa/3.0/igo/legalcode).

Under the terms of this licence, this work may be copied, redistributed and adapted for non-commercial purposes, provided that the work is appropriately cited. In any use of this work, there should be no suggestion that FAO endorses any specific organization, products or services. The use of the FAO logo is not permitted. If the work is adapted, then it must be licensed under the same or equivalent Creative Commons licence. If a translation of this work is created, it must include the following disclaimer along with the required citation: "This translation was not created by the Food and Agriculture Organization of the United Nations (FAO). FAO is not responsible for the content or accuracy of this translation. The original [Language] edition shall be the authoritative edition."

Disputes arising under the licence that cannot be settled amicably will be resolved by mediation and arbitration as described in Article 8 of the licence except as otherwise provided herein. The applicable mediation rules will be the mediation rules of the World Intellectual Property Organization http://www. wipo.int/amc/en/mediation/rules and any arbitration will be conducted in accordance with the Arbitration Rules of the United Nations Commission on International Trade Law (UNCITRAL).

Third-party materials. Users wishing to reuse material from this work that is attributed to a third party, such as tables, figures or images, are responsible for determining whether permission is needed for that reuse and for obtaining permission from the copyright holder. The risk of claims resulting from infringement of any third-party-owned component in the work rests solely with the user.

Sales, rights and licensing. FAO information products are available on the FAO website (www.fao.org/ publications) and can be purchased through publications-sales@fao.org. Requests for commercial use should be submitted via: www.fao.org/contact-us/licence-request. Queries regarding rights and licensing should be submitted to: copyright@fao.org. 


\section{Contents}

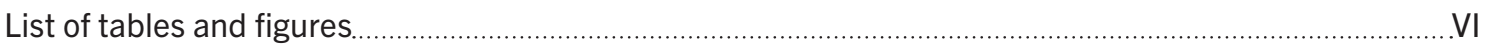

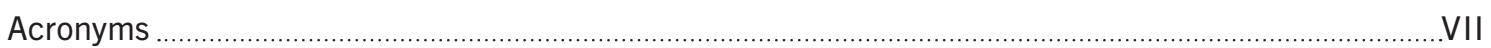

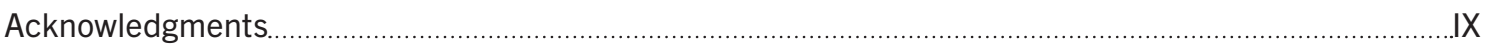

Abstract

Introduction

1. Framing the study: rural migration drivers and structural transformation in sub-Saharan Africa ..........4

1.1 Why is understanding rural migration in Africa important?

1.1.1. Old processes but new context and patterns ...................................................................

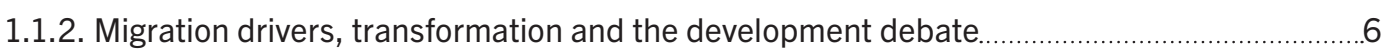

1.2 Selected options for investigating rural migration and its drivers in sub-Saharan Africa ................7

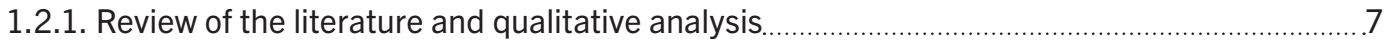

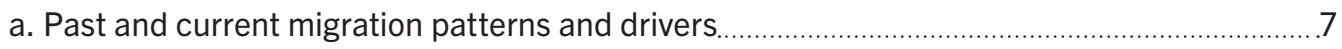

b. Futures studies on migration patterns and drivers ................................................................ 8

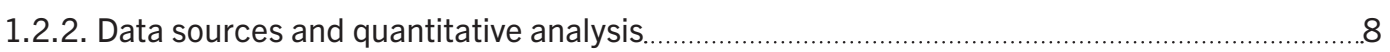

a. The data challenge

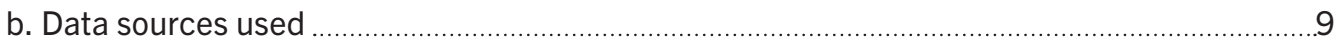

C. Statistical analyses based on the Rural Livelihood Information System (RuLIS) ...................9

2. Building a conceptual framework on the drivers of migration in sub-Saharan Africa...........13

2.1 Determinants, causes and drivers of migration: a needed clarification .......................................13

2.2 A critical literature review of past and present drivers of migration ............................................14

2.2.1. Conventional theoretical approaches: limitations and empirical biases...............................14

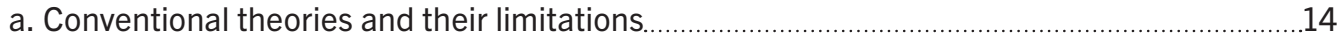

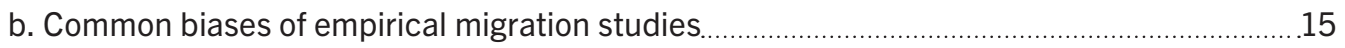

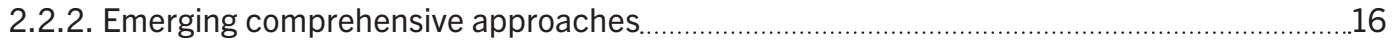

a. The common ground: migration as part of social transformation ...........................................17

b. Integrating micro, meso and macro levels: bringing in capabilities, aspiration and

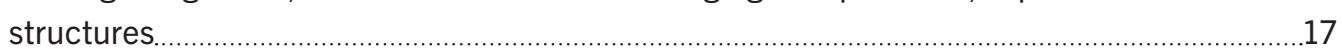

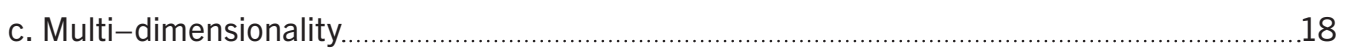

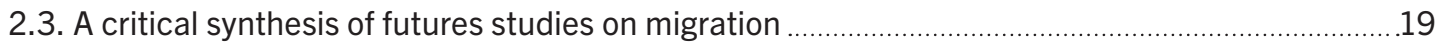

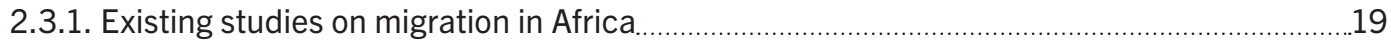

2.3.2. Drivers

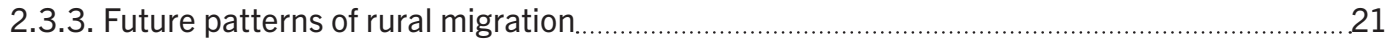

2.4. The proposed framework for analysing the drivers of rural migration.............................................23

3. What do we know about migration dynamics and patterns in sub-Saharan Africa? ..............................27

3.1. A unique demographic context 27 


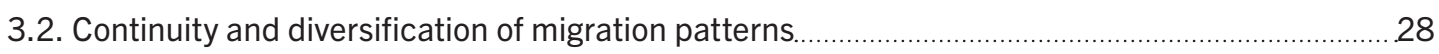

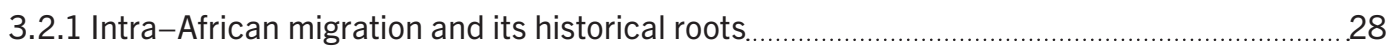

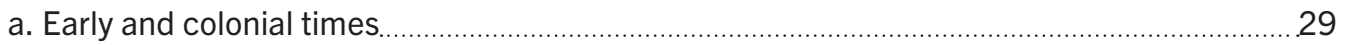

b. Post-independence: between new barriers and tentative integration.....................................30

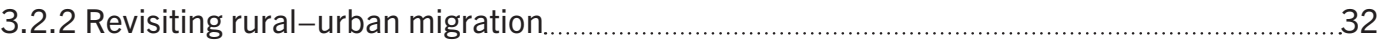

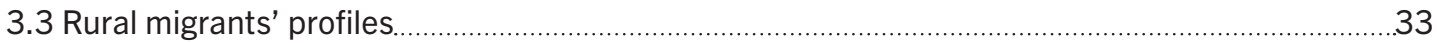

4. Analysing the drivers of rural migration: evidence from available data and case

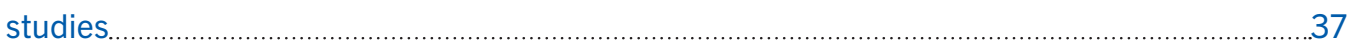

4.1 What do we learn from existing datasets: drivers at individual and household levels ...................37

4.1.1. Reasons for migration at individual level: age, sex and location matters

4.1.2. Reasons for migration at household level: both wealth and relative deprivation drive

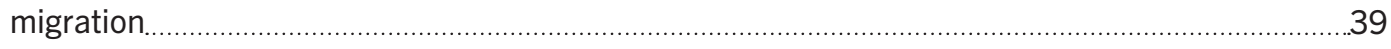

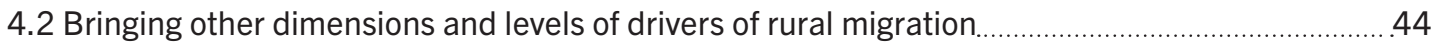

4.2.1. Drivers and patterns of rural migration: main insights from five country case studies ........44

4.2.2. The evolution in time of drivers complexes: the case of Mozambique ..................................47

4.2.3. Climate change: a misleading determinant but a complex driver of migration......................48

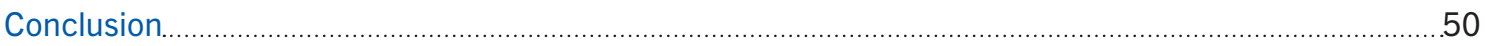

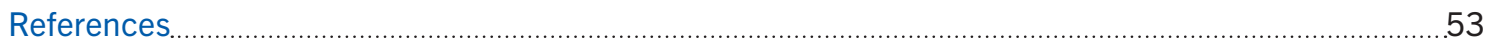

Annexes.

Annex 1: Preliminary assessment of available relevant datasets on migration.....................................62

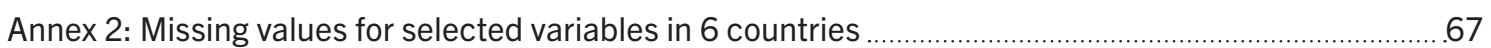

Annex 3: Definition and measurement of variables for the binary logistic model .....................................69

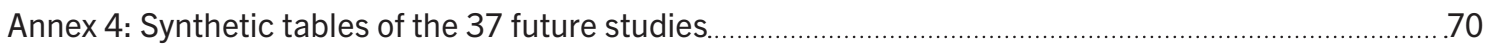

Annex 5: Plausible scenarios for rural migration based on future states of rural areas and global alternative

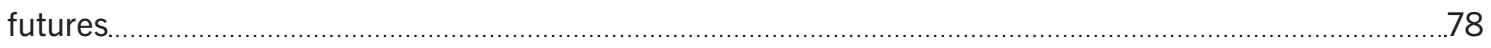

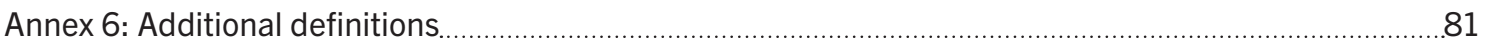

Annex 7: Rural MHH and NMHH profiles: summary statistics for selected variables ............................. 83

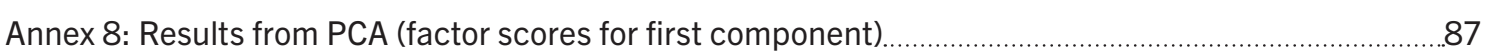




\section{List of tables and figures}

TABLES:

Table 1: Regions and countries selection

Table 2: RuLIS selected countries and survey sample size

Table 3: Main features of 37 identified futures studies

Table 4: Global patterns of migration and potential implications for SSA

Table 5: Reasons for internal and international migration by gender and age group (15-34)

Table 6: Logistic regression results of determinants and drivers of rural out-migration in six African countries

Table 7: Current patterns and drivers of rural migration: synthesis from 5 country case studies

\section{FIGURES:}

Figure 1: The multifaceted drivers of rural migration

Figure 2: Rural and urban migration by destination (selected countries)

Figure 3: Characteristics of rural migrants and migrants' households (selected countries)

Figure 4: Main reasons for migration (rural migrants, selected countries)

Figure 5: Reasons for internal and international migration (selected countries)

Figure 6: Wealth quintiles by rural households' migration status -6 countries 


\section{Acronyms}

\begin{tabular}{|c|c|}
\hline$A U$ & African Union \\
\hline BLR & Binary logistic regression \\
\hline CIRAD & French Agricultural Research Centre for International Development \\
\hline COMESA & Common Market for Eastern and Southern Africa \\
\hline EAC & East African Community \\
\hline ECOWAS & Economic Community of West African States \\
\hline EU & European Union \\
\hline FAO & Food and Agriculture Organization of the United Nations \\
\hline Govlnn & Centre for the Study of Governance Innovation \\
\hline ICT & Information and Communication Technology \\
\hline IDP & Internally Displaced Person \\
\hline IFAD & International Fund for Agricultural Development \\
\hline ILO & International Labor Organization \\
\hline IMI-DEMIG & International Migration Institute - Determinants of International Migration \\
\hline IOM & International Organization for Migration \\
\hline LSMS & Living Standards Measurement Surveys \\
\hline LSMS-ISA & Living Standards Measurement Surveys - Integrated Survey on Agriculture \\
\hline MENA & Middle East and North Africa \\
\hline $\mathrm{MHH}$ & Migrant Household \\
\hline MRHS & Migration and Remittances Households Surveys \\
\hline NELM & New Economics of Labour Migration \\
\hline NGO & Non-Governmental Organization \\
\hline $\mathrm{NMHH}$ & Non-Migrant Household \\
\hline NR & Natural Resources \\
\hline OAU & Organization of African Unity \\
\hline OECD & Organisation for Economic Co-operation and Development \\
\hline PCA & Principal Components Analysis \\
\hline REC & Regional Economic Community \\
\hline RENAMO & Mozambican National Resistance \\
\hline RuLIS & Rural Livelihoods Information System \\
\hline
\end{tabular}


SADC

Southern African Development Community

SDGs

Sustainable Development Goals

SSA

Sub-Saharan Africa

STEEP

Social, Technical, Environmental, Political

UNDESA United Nations Department of Economic and Social Affairs

UNPS Ugandan National Panel Survey

US\$

Dollar of the United States of America

USA

United States of America 


\section{Acknowledgments}

This working paper, together with the atlas on rural migration in sub-Saharan Africa, is the result of a partnership between the Centre of International Cooperation in Agronomic Research for Development (CIRAD) and the Food and Agriculture Organization of the United Nations (FAO). It was prepared by CIRAD in collaboration with the Centre for the Study of Governance Innovation (GovInn), South Africa, and benefited from the financial support of FAO and CIRAD.

The working paper was coordinated by Sara Mercandalli and Bruno Losch (CIRAD, UMR Art-Dev, and GovInn, respectively at the University of Pretoria - UP - and the University of the Western Cape - UWC) who directly contributed to all the sections of the document. The authors benefited from the support of: Robin Bourgeois (CIRAD, UMR Art-Dev, and GovInn at UP), who specifically contributed to the review of future studies related to migration; Jean-François Bélières (CIRAD, UMR Art-Dev, and FOFIFA, Madagascar), who was involved in the exploration and review of existing datasets; Mulugeta F. Dinbabo, Michael N. Belebema and Clement Mensah (Institute for Social Development, UWC), in charge of the data analysis; and Sandrine Fréguin-Gresh (CIRAD, UMR Art-Dev) and Christopher C. Nshimbi (GovInn at UP), who contributed to the section on migration dynamics and patterns.

Technical support, feedback and advice were provided by colleagues from the Statistics Division (ESS) and the Social Policies and Rural Institutions Division (ESP) of FAO. In particular, the authors wish to thank Piero Conforti and Clara Aida Khalil (ESS), Cristina Rapone and Thu Hien Dao (ESP); and Marco Fiorentini (ESP) for the design and layout. 


\section{Abstract}

The paper provides an up-to-date review of the literature on the patterns and drivers of rural migration in sub-Saharan Africa and explores their relation to rural and structural transformation, with the objective of feeding the current policy debate on migration. Based on a mixed approach that combines a critical literature review of past, current and future drivers of migration and analyses of available data, the paper first elaborates a pluri-disciplinary and comprehensive conceptual framework for the understanding of the drivers and patterns of rural migration. It then examines the evolving patterns of African rural migration and presents renewed migration characteristics, which have emerged over the last decades. Beyond the classical one-way rural-urban migration, contemporary African migration is characterized by widespread multi-directional (including rural-to-rural and urban-to-rural), more complex and step-wise movements with forms of circular migration. It results in double-way and continuous relations of rural migrants with their areas of origin. These patterns support socio-economic linkages within and across space and sectors, which challenge the conventional knowledge on the processes of rural change. They reveal that migration is performing a range of socio-economic functions far beyond the only transfer of labour from agriculture to other sectors and from rural-to-urban areas. As such, they highlight possible new structural transformation paths, responding to existing challenges faced by the region in terms of demographic and economic transition. The paper finally discusses the characteristics and dynamics of the drivers using existing datasets and case studies. It highlights the diverse and multifaceted anture of the drivers of rural migration and the way they act in combination to shape African rural migration dynamics and their links to contemporary regional and sectoral dynamics. 



\section{Introduction}

This working paper is a companion of the FAO-CIRAD atlas on rural migration in sub-Saharan Africa: Rural Africa in motion. Dynamics and drivers of migration South of the Sahara, published respectively in 2017 and 2018 for the English and French versions (Mercandalli and Losch, eds., 2017, 2018). Despite a delayed publication, it was drafted in parallel to the preparation of the atlas and both documents benefited from cross-fertilization between literature review, data mining, case studies and the process of designing illustrations for the two-page thematic and country case spreads of the atlas.

In spite of headlines, migration is not a new phenomenon. It is rooted in world's history, and movements between and across continents and regions spread long before the general development of nation-states. It is fully part of the permanent process of change of every society and it has always been an inherent contributor - and result - of structural transformation. The progressive shift of humankind from rural societies to cities has been fueled by a continuous process of rural-urban migration which accelerated over the last two centuries and developed worldwide.

Sub-Saharan Africa (SSA) is no exception. It has a long history of internal and international migration, by choice or by constraint, and movement of people deeply shaped the region. According to available statistics, about 33 million Africans were living outside their country of nationality in 2015. It represents 2.8 percent of the total population of the continent and only 14 percent of international migrants worldwide (UNDESA, 2015).

However, migration in sub-Saharan Africa is specific. Contrary to North Africa where the great majority of migrants cross the continental borders to reach Europe, people in SSA tend to move mostly to neighbouring countries or within the region. Out of 23 million SSA's international migrants, 70 percent (16 million) stay in the region. ${ }^{1}$

This reality of international migration is underestimated due to the importance of undocumented migrants across borders. However, the focus on international movement of people masks the massive internal migration, within countries, - for which accurate information is even more scarce - and estimated globally to be six times greater than international migration.

The bulk of internal migration corresponds to rural-urban migration flows which are central in the historical process of change. In this working paper, rural migration (or rural-out migration) is defined in a broad way as any spatial movement of people from rural areas to urban or other rural areas, within or between countries, for social, economic, political and environmental reasons, and implying or not a change of residence, on short term or long-term bases.

Together with urbanization, rural migration continues to fuel African structural transformation. However, due to the characteristics of the demographic and economic transition in SSA, with a booming population and limited economic opportunities in cities (compared to past transitions in other regions), migration patterns have evolved. They also have significantly affected the characteristics of rural-urban dynamics and their role in economic transition.

Indeed, sub-Saharan migration presents a diversified picture in terms of mobility patterns and destinations at both internal and international levels. In particular, the dynamics of circular or nonresidential migration, between and within countries, are a direct answer to the challenges faced by rural households.

\footnotetext{
${ }^{1}$ UNDESA released new data on migrant stocks in 2019 after the preparation of this working paper and the publication of the atlas. The new estimates indicate $\mathbf{4 0 . 2}$ million African migrants, which corresponds to a limited increase of 7 million and to the same share of international migrants ( 14.8 percent) compared to the data used in this working paper from 2015. In particular, 28 million African migrants are from sub-Saharan Africa and 65 percent of them migrate within the region (UNDESA, 2019).
} 
They result in growing multi-local and multi-active household strategies which are a renewed component of the structural transformation process. Because they contribute to strengthening a variety of socioeconomic and spatial linkages, they support the development of new territorial dynamics rooted in a deeper rural-urban interface, which is reshaping the processes of change.

Yet, despite their critical role in local and national development, such migration dynamics remain broadly unknown and their positive contribution to structural transformation is rarely acknowledged. This is why it is key to unravel the migration mechanisms at play and to identify their different drivers - as factors that induce, orient and sustain migration - in spite of a variety of contexts.

As such, the objective of this working paper - which does not address the specific case of forced displacement - is to offer a review and a better understanding of the diverse and multifaceted drivers of rural migration. It is also to explore the way they act in combination to shape the current migration patterns, and to investigate their contribution to contemporary spatial and sectoral dynamics and to structural transformation.

In addition to reviewing the existing knowledge base, the document provides a synthesis of rural migration dynamics and offers a comprehensive approach on the drivers and determinants of migration, in perspective with the process of structural transformation in sub-Saharan Africa. It aims at informing policy design for a better articulation of migration realities to public action.

The document, first, proposes a discussion of rural migration as part of the structural transformation process in SSA, and its relation to the development debate. Then, the methodological choices combining literature review and data analysis are presented (section 1). This mixed approach is used to propose a conceptual framework based on a critical literature review of past, current and future drivers of migration (section 2), before examining the evolving patterns of African rural migration (section 3). The paper finally discusses drivers' characteristics and dynamics using existing datasets and case studies (section 4). 


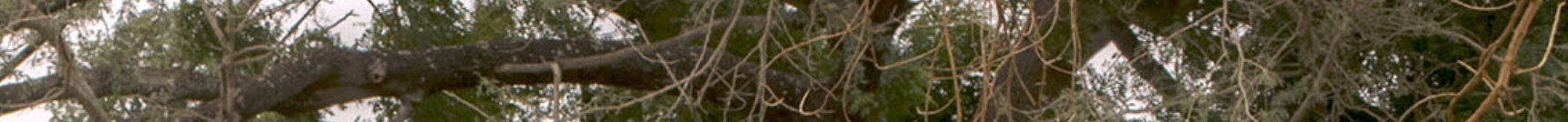
to.
(4)

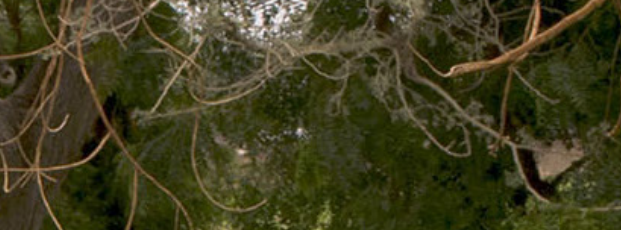

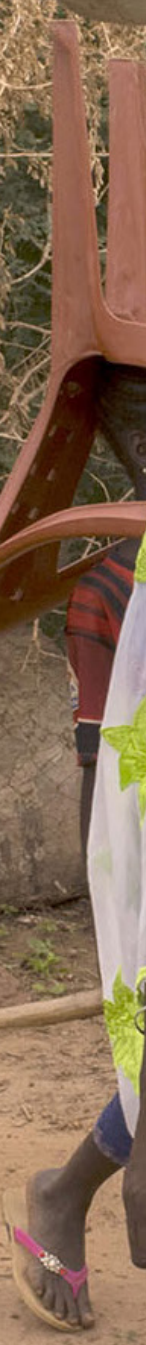

4 (5) -4

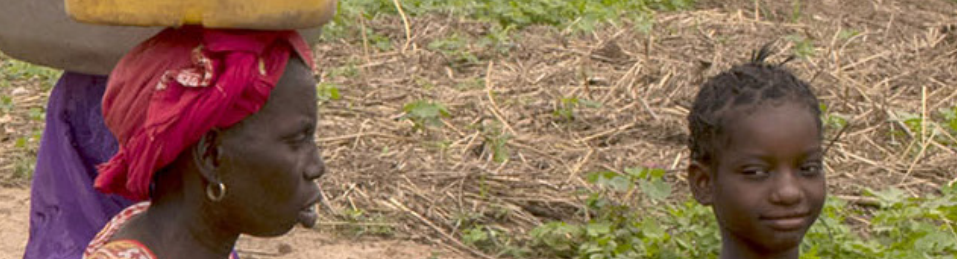

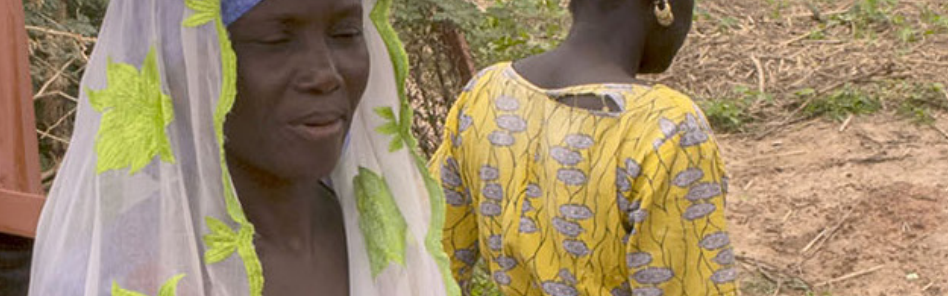

I

12 (5)

1
10
10
$-\infty$

7.

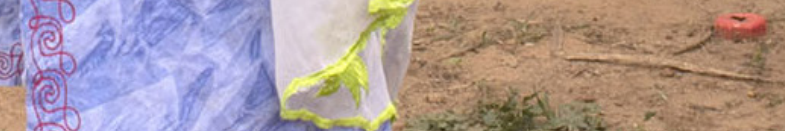

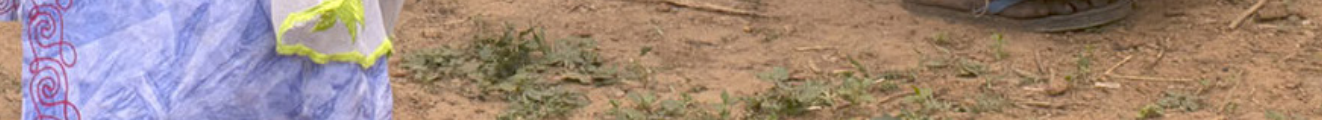

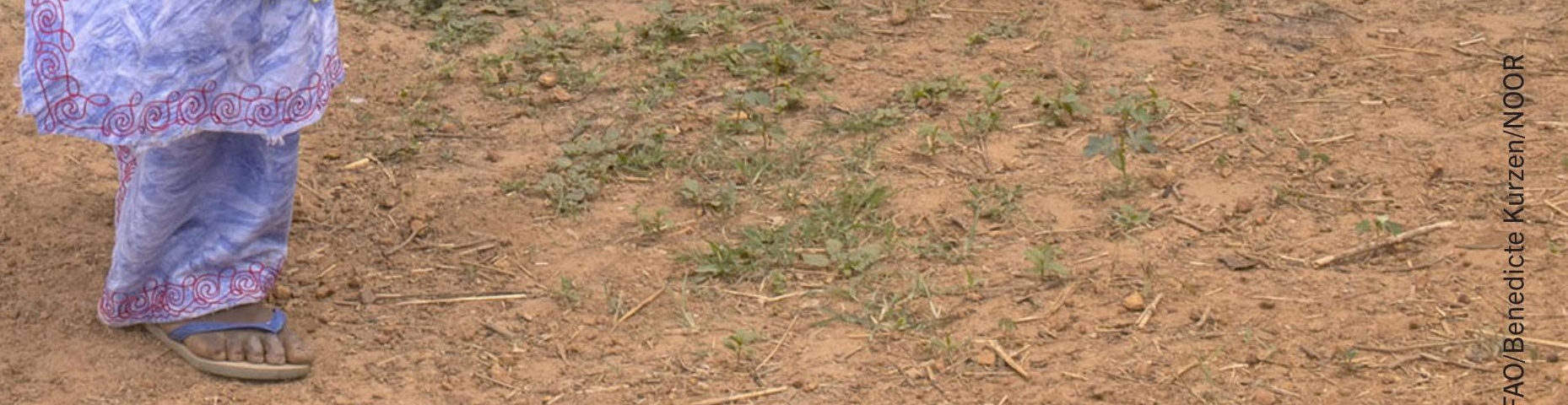




\section{Framing the study: rural migration drivers and structural transformation in sub-Saharan Africa}

Migration is a key component of the structural transformation process taking place in Africa. It plays a critical role in national and sub-national development and is an important response to major challenges faced by the continent, like youth unemployment and environmental and social sustainability.

As such, rural migration dynamics require due attention. The section reminds the place of migration in development processes and why it needs to be reconsidered (1.1). Then, it presents the methodology adopted in the working paper in order to address existing data and conceptual limitations and to comprehensively explore the drivers and patterns of rural migration. It advocates for adopting a mixed approach based on quantitative and qualitative methods (1.2).

\subsection{Why is understanding rural migration in Africa important?}

\subsubsection{Old processes but new context and patterns}

Rural migration is fully part of structural transformation, which refers to changes overtime in the sectoral and spatial distribution of economic activities and people. A stylized summary of this process and its main determinants show the gradual transition from an agriculture-based economy to one based initially on industry and then on services, in conjunction with urbanization and a geographic population shift from rural to urban areas.

This transition results from major technological changes supported by the adoption of fossil fuels which led to impressive productivity gains facilitating the transfer of labour and capital from agriculture to other economic activities. This process was accompanied by a progressive spatial restructuring from scattered activities (agriculture) to more concentrated ones (industry), and a migration of labour and people from rural areas to cities unlocked by huge progresses in transport and communication.

Structural transformation occurred and continues at different paces and according to regional characteristics. Its general pattern, which is supported by statistical evidence (Johnston and Kilby, 1975), was observed first in Western Europe in the late eighteenth century with the agricultural and industrial revolutions; it then reached its major offshoots, ${ }^{2}$ Eastern Europe and Japan in the nineteenth and early twentieth centuries, and developed next in other regions, albeit more unevenly, mainly after the Second World War.

In this process, Europe benefited immensely from its military and political hegemony, which gave it access to settler colonies and captive markets with little competition. Asia and Latin America (with many variations) were able to rely on vigorous state-led modernization policies (Giraud, 1996), which continued until the late 1970s corresponding to the economic liberalization of the world economy and the beginning of globalization (Amsden, 2001).

Sub-Saharan Africa did not benefit from the same historical sequence, which explains why the subcontinent lags behind with regard to its structural transformation. New African states only and mostly gained their independence from the 1960s, inheriting the former colonial borders with poor infrastructure and skilled human resources.

${ }^{2}$ The United States of America and Canada, Australia and New Zealand, and other countries such as Argentina with significant European settlements. 
They all had to adopt very restrictive structural adjustment reforms after two decades, or less, of partially autonomous public policies, and they engaged in globalization under very asymmetric conditions with regard to other regions and competitors.

These intertwined factors explain why SSA is characterized by the importance of its primary sector (extractive industries and agriculture), the relative importance of its rural population, and a unique urbanization process without industrialization (Losch et al., 2012).

With regard to the role of international migration in the transformation processes, Europe was characterized by a massive migration of about 60 million people to other continents. It facilitated the absorption of labour surpluses exiting agriculture and facing limited opportunities in the context of early industrialisation (Hatton and Williamson, 2005). Such migration was not replicated in other regions due to geopolitical position of Europe till after the Second World War. Chinese and Indian diasporas, migrants from South Asia and the Philippines to the Gulf countries, from North Africa to Western Europe, from Mexico and Central America to the United States, have all played a significant role in their respective countries, but a process of the magnitude of European migration cannot anymore take place. ${ }^{3}$ In the current geopolitical order of partial globalization, borders are mostly closed to people, with hardening of controls, although largely open to capital, goods and many services. Yet, if borders were open, people would certainly move (Pritchett, 2006).

With regard to the role of internal migration, the traditional rural-urban intersectorial transfer of labour fuelled most of structural transformation processes (Fei and Ranis, 1964). The structural characteristics of SSA, with limited industrialization and a major development of the informal sector (less lucrative and more vulnerable than waged labour), prevent rural to urban migration to perform the same historical role (de Brauw et al., 2014).

New pathways are developing, with new migration dynamics between rural and urban areas, within and between African countries. They are playing an under-acknowledged role in the African structural transformation process (Suttie and Vargas Lindus, 2016; CNUCED, 2018; FAO, 2018). Rural-urban migration remains a prominent feature but it actually coexists with rural-rural or urban-rural migration, either short or long term, as well as growing circular movements consisting in recurrent migration between a place of origin and one or more places of destination, both at internal and continental levels.

The greater diversity of African migration patterns is also due to the presence of gradually more connected societies and growing population densities (a process also observed elsewhere). Rural migration is central to rural-urban linkages (Evans, 1990) and contributes to the spatial and sectoral restructuring through new connections between rural and urban spaces. First, rural households diversify their employment and income strategies engaging in a multiple range of non-farm activities that used to be part of the urban domain (Bryceson, 2002). Accordingly, many households are multi-sited: their members live or work across the urban-rural divide (Tacoli, 2002; Losch, 2015). Last, cultural references and practices in rural areas are also changing, due to improved transportation networks, and the spread of communication means such as mobile phones, internet, and television. This contributes to the narrowing of the rural-urban divide and the rising of new territorial dynamics illustrated by the increasingly interlocked nature of rural and urban spaces resulting from an urbanization from below, with rural boroughs rapidly becoming rural towns connected by growing small settlements (Losch and Magrin, 2016).

This process takes particularly place in the spreading rural-urban interface where provincial cities and small towns already account for more than the 20 percent of the total African population (Berdegué and Proctor, 2014). These socio-spatial arrangements embodied in rural urban spaces affect an increasing share of the rural population. The resulting emerging functional territories correspond to a new socioeconomic system based on interconnectivity and permanent flows of people, goods, services, and capital.

\footnotetext{
${ }^{3}$ The estimated migration of 60 million Europeans between 1850 and 1930 (major uncertainties remain between migrant stocks and flux due to migrants' return to their home country) as to be compared to the European population which grew from 210 million to 365 million over the period (Maddison, 2010). In order to grasp the magnitude of the process, it corresponds to about 20 percent of the European population at this time.
} 
They share deeply entrenched informal and progressively formal institutions that are shaping social and economic life, as well as the way these territories connect and interact with the broader forces and trends of national development (Berdegué and Proctor, 2014a). These territorial dynamics facilitate rural transformation.

Contrary to urban concentration which can perpetuate rural marginalisation, a smoother and less asymmetric urbanization linkages are easier between these smaller urban centres and their rural hinterlands, where the majority of the poor live (Christiaensen and Todo, 2014; Losch et al., 2015; Akkoyunlu, 2013; Steel et al., 2019).

\subsubsection{Migration drivers, transformation and the development debate}

The drivers of migration are generally described as factors or forces - internal or external to the household - that influence decisions to migrate as well as the patterns of migration. ${ }^{4}$

The literature on the topic stresses the limited understanding of the mechanisms driving migration, and particularly the one originating from rural areas. Over the last decades, theoretical research on the nature and causes of migration processes did not advance much (Arango, 2000; Bakewell, 2010): progresses in research on migration drivers are constrained by data issues and division between economics and other social sciences, as well as between qualitative and quantitative approaches (Boswell, 2008; de Haas 2011b). As a result, "although there is consensus that macro-contextual economic and political factors and meso-level factors, such as networks, all play some role [in starting or sustaining migration], there is no agreement on their relative weight and mutual interaction" (de Haas, 2011b).

Yet, considering the role of rural migration in SSA's transformation, it is important to unravel the mechanisms at stake in the migration process, identifying different drivers, their significance and combination, as well as the variety of socioeconomic and spatial linkages and spatial transformation they support, in spite of a variety of contexts.

Rural-urban linkages have been a core issue in theoretical and policy debate, particularly since Lewis (1954) developed his dual sector model. In earlier days of development economics, building linkages between rural and urban economies was a matter of policy choice: in Lewis' approach it was about fostering urbanization and industrialization at the cost of rural societies and agriculture (Berdegué and Proctor, 2014a). After a long eclipse when sectorial approaches to development prevailed, the importance of rural-urban linkages for an effective and more balanced territorial development is increasingly acknowledged today.

However, the relation between migration and development remains a difficult one to establish. Indeed, despite the increased attention on migration in development studies during the 1990's, migration still tends to be considered as "an isolated, marginal or transitory variable" (de Haan, 2006). Numerous empirical studies point that the role of migration in the socio-economic transformation processes is both complex and heterogeneous (de Haas, 2010a), and also fully part of the migration - development nexus due to their interlinked nature (Nyberg-Sorensen et al., 2002); but the impression is still that of two independent phenomena in interaction (Skeldon, 1997, 2008).

Converging with works in other fields of research about the myth of rural immobility (Amselle et al., 1978; Le Bris et al., 1985; Skeldon, 1990; Milbourne, 2004), Mc Dowell and de Haan (1997) and de Haan (1999), the contention emerges that most of development studies are based on the wrong assumption that sedentary pattern within the society are the norm, instead of considering that migration is often the rule rather than the exception. These debates are also directly related to the increasing acknowledgement of the significance and contribution of population movements to diversified livelihoods (Cramer and Pontara, 1998; Ellis, 2003; Ellis and Freeman, 2004), and to the insufficient visibility of livelihoods diversification in theories of agrarian change (Ellis, 2000).

\footnotetext{
${ }^{4}$ See section 2 for definitions of concepts used in the paper.
} 
From the unsettled relation between migration and development (Papademetriu and Martin, 1991), the debate progressively moved toward a new paradigm where migration is considered as "a process which is an integral part of broader transformation processes embodied in the term 'development'; but also has its internal, self-sustaining and self-undermining dynamics; and impacts on such transformation processes in its own right" (de Haas, 2010a). Research from other disciplines grounded in broader theories of social change also support this new approach (Castles, 2008).

This working paper, by drawing a comprehensive interdisciplinary framework about drivers of rural migration, adopts the pluralist approach characterizing this new paradigm (de Haas, 2010a; Skeldon, 2008; de Haan, 2006; McDowell and de Haan, 1997; Mercandalli, 2015). It considers that theorising migration as part of socioeconomic change is crucial for this field of research. In this perspective, migration is not seen as an "exceptional, problematic, and reactive process, but as a complex, patterned, multidimensional, and dynamic phenomenon" (de Haas, 2011a). This paradigm change in the understanding of migration dynamics gives them a core position in the policy debate and calls for their entire consideration in policy design.

\subsection{Selected options for investigating rural migration and its drivers in sub-Saharan Africa}

Facing the difficulty of investigating rural migration in SSA, this working paper rests on a combination of literature review and a limited selection of existing datasets. These sources and how they were used are presented below.

The geographical scope of the paper is sub-Saharan Africa with a focus on eleven countries in four African Union regional economic communities for which available information was supporting a deeper analysis of rural migration drivers and patterns (cf. table 1).

Table 1: Regions and countries included in the study

\begin{tabular}{|c|c|c|c|c|}
\hline Country/ Region & $\begin{array}{l}\text { East African } \\
\text { Community } \\
\text { (EAC) }\end{array}$ & $\begin{array}{c}\text { Economic } \\
\text { Community of } \\
\text { West African } \\
\text { States (ECOWAS) }\end{array}$ & $\begin{array}{l}\text { Southern African } \\
\text { Development } \\
\text { Community } \\
\text { (SADC) }\end{array}$ & $\begin{array}{l}\text { Common Market } \\
\text { for Eastern and } \\
\text { Southern Africa } \\
\text { (COMESA) }\end{array}$ \\
\hline $\begin{array}{l}\text { Datasets } \\
\text { (see section 4.1) }\end{array}$ & Uganda & $\begin{array}{c}\text { Ghana, Mali, } \\
\text { Nigeria }\end{array}$ & Malawi & Ethiopia \\
\hline $\begin{array}{l}\text { Case studies } \\
\text { (see section 4.2) }\end{array}$ & - & Senegal & $\begin{array}{c}\text { South Africa, } \\
\text { Zambia, } \\
\text { Madagascar, } \\
\text { Mozambique }\end{array}$ & - \\
\hline
\end{tabular}

\subsubsection{Review of the literature and qualitative analysis}

\section{a. Past and current migration patterns and drivers}

The theoretical and empirical literature on drivers and determinants of migration was first reviewed ${ }^{5}$ and critically discussed, stressing the convergence, controversies and limits in existing research, as well as its latest development. The specific knowledge about rural migration was particularly addressed.

${ }^{5}$ A preliminary literature review commissioned by FAO was used as an input (Laws and Avis, 2017) 
The conceptual framework on drivers of rural migration resulting from this review (section 2) draws on and develops the concept of drivers complexes.

The following review of migration patterns and dynamics (section 3) does not pretend to be exhaustive but draws from existing macro data and macro studies at the continental level, and from regional and sub-regional studies. Main stylized facts and features of regional migration dynamics are proposed adopting a historical perspective.

Country case studies prepared for the atlas on rural migration in SSA were used to illustrate the drivers of rural migration (section 4), their different levels (micro, meso, macro) and dimensions (socio economic, political, environmental, demographic). Examples of drivers complexes are proposed. In spite of incomplete, heterogeneous and limited information derived from these examples, the comparison allows for partial conclusion about the nature of drivers' complexes.

\section{b. Futures studies on migration patterns and drivers}

Futures studies are "a field of studies, focusing on a methodical exploration of what the future might be like" (GFAR, 2014). They include forecast (or projection) defined as "a statement that something is going to happen in the future, often based on current knowledge and trends" and foresight (exploration) defined as "a systematic, participatory and multi-disciplinary approach to explore mid- to long-term futures" (GFAR, 2014).

The reviewed futures studies were grouped into three categories: forecast/projection, foresight/ exploration and analytical approaches. Forecasting studies intend to predict migration flows and intensity based on projections, while foresight studies intend to explore alternative migration flows and intensity based on plausible scenarios. Analytical studies have no explicit reference to projections or scenarios, but contain elements of analysis related to drivers and determinants of migration.

A systematic inventory combining sets of keywords was conducted first through a search of major journals in the field of futures studies. ${ }^{6}$ Then, the same sets were used for searching web-based literature sources (Scopus, Science direct, Mendeley) for additional articles, books and various reports. Publications before 2000 were not included in the search. The relevance of all futures studies identified was then assessed by the authors using four criteria (highly relevant, relevant, somehow relevant, and slightly/marginally relevant).

\subsubsection{Data sources and quantitative analysis}

\section{a. The data challenge}

Accessing relevant data on migration is a major challenge, particularly for rural migration, because mobility is most often an obstacle to measurement and statistics. ${ }^{7}$ Available data for analysing internal and international migration, as well as understanding structural transformation, is not consistent and not harmonised across countries and regions (FAO, 2018).

For international migration, the United Nations Population Division (UNDESA) is the major source of reference. Its Trends in International Migrant Stock rely on and harmonise data from national population censuses to estimate numbers of international migrants. However, census-based data used to assess international and also internal migration are often uneven in terms of content and quality and they frequently include limited items about migration. This is particularly the case in SSA where the weakness of many national statistical systems related to constraints on resources affects the availability and quality of data and regular updates (in some countries the last population census was implemented more than 20 years ago).

${ }^{6}$ The following was used: "migration" and "scenario" and "Africa"; "migration" and "projection" and "Africa"; "migration" and "future" and "Africa".

${ }^{7}$ Annex 1 displays a preliminary assessment of existing data sources on rural migration. 
In addition to difficulties about the estimated numbers of migrants, only a limited number of countries have developed specific surveys on migrant households and on the measurement of remittances. ${ }^{8}$ As a result, data on migrants' characteristics (age, gender, rural/urban location, occupations and skills, working conditions and wages, social protection etc.) is very fragmented and prevents aggregation at national level and comparison.

Temporary and transit migration is not reported, which explains for instance the lack of information about migration from SSA to north Africa. These two types of migration are partly included in informal migration data from the International Organization for Migration (IOM) (IOM, 2008; AfDB, 2014). Short-term (i.e. for less than 12 months) and seasonal migration are also difficult to capture. Similarly, statistics on labour migration as well as reliable estimates of the economically active migrant population at the regional level are lacking, despite efforts by ILO to include labour migration modules in censuses and to implement labour force surveys.

Overall, due to the limitations of census-based data, research on migration mostly relies on indirect sources, notably on existing household surveys with thematic focuses - like agriculture or health ${ }^{9}-$ that $^{2}$ are not specifically designed to capture migration. The major constraint of these different sources is the limited possibility for cross-country analysis due to non-standardized methodology.

\section{b. Data sources used}

In this paper, UNDESA is the major source of data on international migrant stocks (UNDESA, 2015) as well as for population trends used in the discussion (UNDESA, 2017, 2018).

For microdata, the paper uses the Migration and Remittances Households Surveys (MRHS) and Rural Livelihoods Information System (RuLIS). MRHS are single-round, cross-sectional surveys conducted in six countries (Burkina Faso, Kenya, Nigeria, Senegal, South Africa, and Uganda), coordinated by the World Bank and implemented between 2009 and $2010 .{ }^{10}$ However, the lack of panel data is a major limitation for the study of migration dynamics and determinants over time. In addition, some MRHS datasets are only representative at the sub-national level, ${ }^{11}$ even if standardized survey instruments were used across the board (Plaza, Navarrete and Ratha, 2011). This limitation prevented national-level comparative analysis. Further, a number of agriculture-related important variables, such as farm size or assets, are not captured in MRHS surveys. Finally, the absence or scarcity of data on issues such as circular migration or the use of remittances for investments (notably in agriculture) prevents an effective understanding of migration practices, their impacts and the interrelations between migration and structural transformation in SSA.

This is why specific quantitative analyses (presented in sections 3.2 and 4.1) were based on variables and indicators produced by RuLIS, an initiative developed by the FAO Statistics Division in collaboration with the World Bank and IFAD and using nationally representative panel household surveys. Starting from the recognition that information on rural income and livelihoods are still scarce and sparse, RuLIS puts together in a harmonized dataset information on rural incomes, livelihoods and their evolution. Where household budget surveys are available, notably the World Bank's Integrated Survey on Agriculture (LSMS-ISA), RuLIS also includes data on the incidence of internal and international migration and the economic conditions of households with and without migrants.

\section{Statistical analyses based on the Rural Livelihood Information System (RuLIS)}

Bivariate and multivariate statistical analyses were developed for this working paper only using the RuLIS datasets.

\footnotetext{
8 This is the case of the Migration and Remittances Households Surveys (MRHS). See below.

${ }_{9}^{9}$ For example, the Health and Demographic Surveillance Systems (HDSS) or the Living Standards Measurement Study - Integrated Survey on Agriculture (LSMS-ISA)

${ }^{10}$ The South Africa MRHS dataset was not used in this report because it is only representative in two provinces.

${ }^{11}$ This is the case for Burkina Faso, Kenya and South Africa
} 
Aggregating RuLIS and MRHS surveys would have required a considerable investment in time definitely beyond the frame of this work and questionable due to the many raw data limitations.

If RuLIS provides a very useful and unique set of harmonized data, it relies on original raw data sources that are heterogeneous in quality and scope. It results in several issues related to missing variables, missing values, and sometimes inconsistencies (in variable names, labels and values), which are presented in Annex 2. In order to deal with these issues, a significant preparatory work was developed for managing the missing values, which were excluded for the statistical work, and for the control of variables before their selection under the condition they were available for all the countries.

Table 2 presents the sample size for the six selected countries. Due to data and time limitations, the statistical analyses developed in the paper only represent a preliminary stage with successive descriptive and inferential statistics for which all tests adopt the 1 percent and 5 percent significance levels. The main caveat related to the results is the endogeneity of migration variables (discussed further in sections 2.1 and 4.1): because the analyses rely on a single wave (year) of surveys, they do not allow to capture the direction of causality between migration and the selected variables (Tegegne and Penker, 2016).

Table 2: RuLIS selected countries and survey sample size

\begin{tabular}{|l|l|l|l|l|}
\hline \multirow{2}{*}{ RULIS Country } & \multirow{2}{*}{ Survey Year } & \multicolumn{3}{|c|}{ Sampled Households } \\
\cline { 3 - 5 } & & Urban & Rural_ & Total \\
\hline Ethiopia & $2015-16$ & $1682(34.0 \%)$ & $3272(66.0 \%)$ & 4954 \\
\hline Ghana & 2013 & $7445(44.4 \%)$ & $9327(55.6 \%)$ & 16772 \\
\hline Malawi & 2013 & $1046(26.1 \%)$ & $2954(73.9 \%)$ & 4000 \\
\hline Mali & 2014 & $1405(36.9 \%)$ & $2399(63.1 \%)$ & 3804 \\
\hline Nigeria & $2012-2013$ & $1501(31.3 \%)$ & $3299(68.7 \%)$ & 4800 \\
\hline Uganda & $2013-2014$ & $816(26.2 \%)$ & $2302(73.8 \%)$ & 3118 \\
\hline
\end{tabular}

Source: FAO - RuLIS

A comparative bivariate descriptive analysis for rural and urban migrant households, as well as for rural migrant households ( $\mathrm{MHHs}$ ) and non-migrant households (NMHHs), was first developed in order to provide key socio-demographic information on rural out-migrants' profiles. T-tests and Pearson's chisquare were used to identify any significant associations and differences between rural $\mathrm{MHH}$ and $\mathrm{NMHH}$ (David and Gunnink, 1997; Markowski and Markowski, 1990). When Pearson's chi-square checks the existing relation (dependence) between variables, t-tests were implemented to find out whether continuous variables as highest years of education, female share of household labour, household size, size of land owned, livestock owned and household head age deferred significantly between $\mathrm{MHH}$ and NMHHs.

Then, a multivariate analysis on the drivers and patterns of migration was carried using principal components analysis (PCA) and a binary logistic regression (BLR). They were used to compare the group of $\mathrm{MHH}$ and $\mathrm{NMHH}$ and, subsequently, to discuss the role of a selected number of variables.

PCA is a method for reducing a complex set of possibly correlated variables into a reduced set of principal components (Filmer and Pritchett, 2001; Balen et al., 2010; Vyas \& Kumaranayake, 2006). Cognizant of the complexity or the absence of standardised income and expenditure data across country surveys, PCA is often used to generate relative wealth indices using household/individual assets. According to Filmer and Pritchett (2001: 128), PCA "provides plausible and defensible weights for an index of assets to serve as a proxy for wealth". For this study, PCA was computed for each of the six countries using variables on households' living conditions: housing features, household ownership of material assets and 
households' access to basic infrastructure and social services. PCA were carried for two main reasons. The first reason was to understand how each of the included variables contributed to household socioeconomic status in its rural context. The second and most important reason was to estimate a relative wealth indicator using the first component of the PCA (Balen et al., 2010; Córdova, 2009), and then to generate clusters (quintiles) to assess how $\mathrm{MHH}$ and $\mathrm{NMHHs}$ compare along each quintile.

The BLR (Agresti, 2002; Hilbe, 2009) was used to model the determinants of rural out-migration for each of the six countries, i.e. to assess the predictors of rural out-migration decisions at the level of the household. The decision to model rural out-migration using the household as a unit of analysis stems from the assumption that family members collectively make migration decisions with the prospective individual migrant - an approach which has its roots in the New Economics of Labour Migration (NELM) (Stark, 1991). Consequently, rural households' migration decision (migrant-household=1, non-migrant household=0) was modelled alongside ten explanatory variables reflected in the literature on drivers of (rural) migration. Annex 3 presents definitions and measurements of these variables. They are drawn from three main domains of household characteristics: demography, human capital and economic wellbeing. Traditionally, these variables have been found to be important drivers or determinants of migration (Tegegne and Penker, 2016) albeit varying results exist in different contexts. The BLR used for analysing the drivers of rural out-migration in this paper is a function of a combination of both push-pull factors. 
$+1,12:=$ $3 x=5$

thes

How 1000

(3)

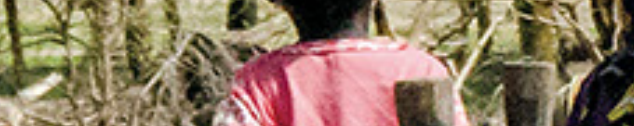

23.0602

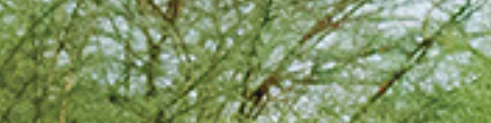

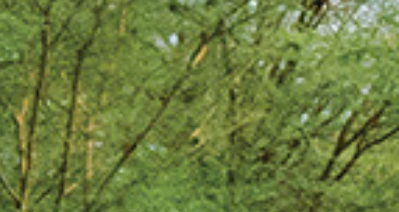

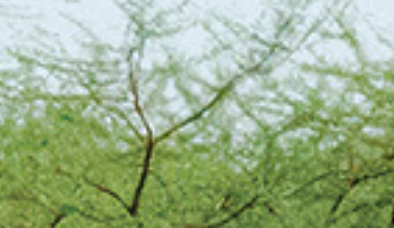
(b.t. tiv. $12=2 \times 10$

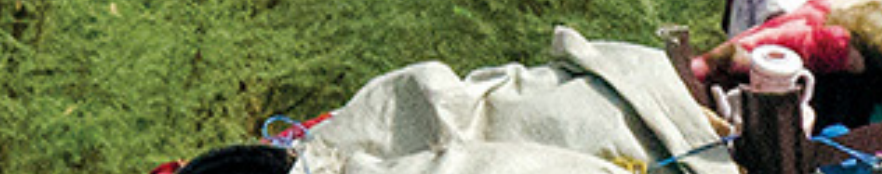
10 (5) $\left.x^{2}\right)^{2}=$ 1.

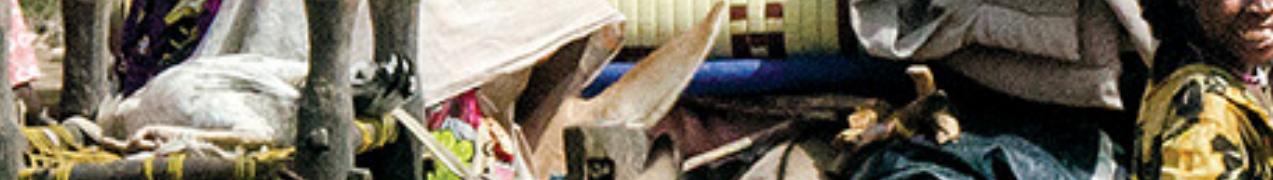

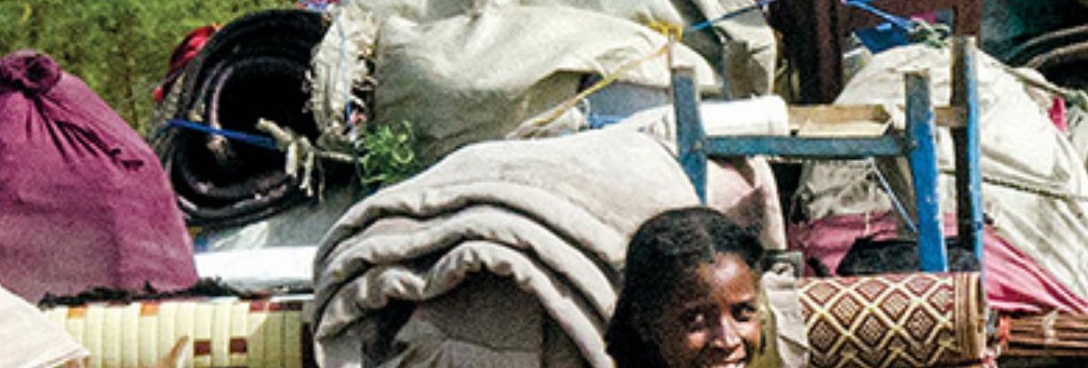

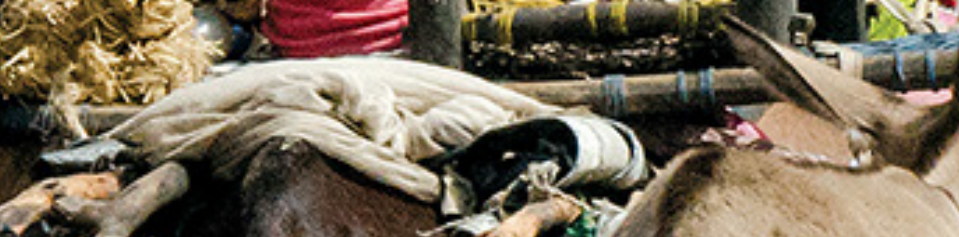
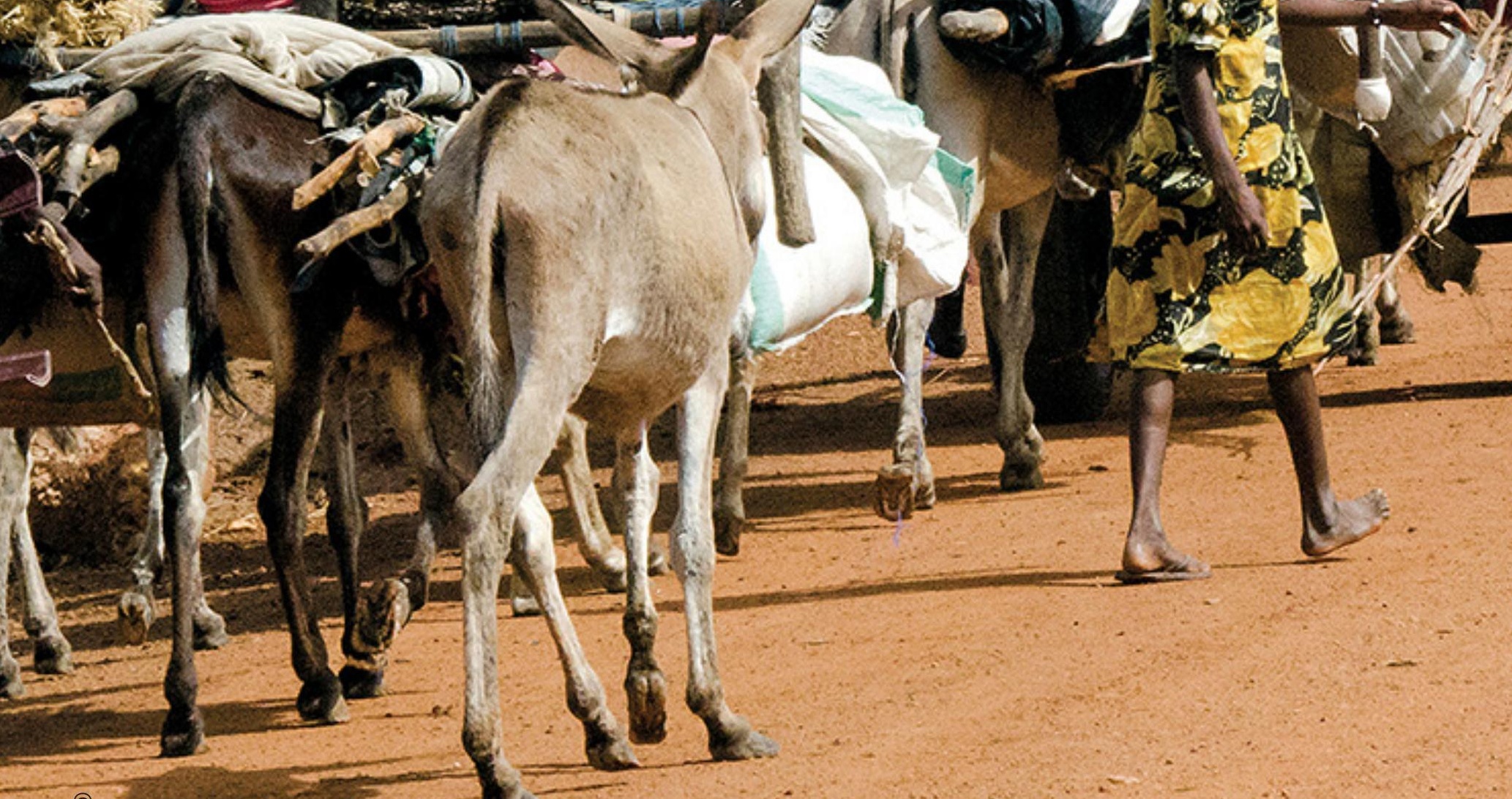


\section{Building a conceptual framework on the drivers of migration in sub-Saharan Africa}

This section presents two core issues about conceptualizing the drivers of migration. The first issue, acknowledging that there is a lack of conceptual clarity about determinants and drivers, is a tendency to exclusively consider economic factors at the national level as the determinants of migration. The second issue is the belief that there is a simple, deterministic mono-causal linear relation between a driver of migration and a migration pattern.

In order to address these issues, after a clarification of the main concepts used in the working paper (2.1), a review of the literature on the current drivers of migration (2.2) is associated with a review of futures studies (2.3). It highlights the concept of drivers complexes and its relevance for building a conceptual framework with an interdisciplinary perspective (2.4).

\subsection{Determinants, causes and drivers of migration: a needed clarification}

In the long-standing research about the explanatory factors of migration, several concepts have been used with often unclear and shifting definitions. Determinants, drivers and causes are the most critical:12 they reflect different approaches, their primacy in the literature has changed overtime, but they are still broadly and unduly used indifferently, which calls for a clarification of their definition and usage.

Determinant seems to remain the dominant concept in most studies. Determinants are the primary factors in a broader set of contributing factors of migration. However, there is a very large tendency to conclude that all factors of migration are determinants - a consequence of research practice which often focuses on specific (isolated) factors. From the literature review, it appears that few researchers look at differentiating determinants of migration within a set of drivers. The same occurs with causes of migration.

The reference to causes of migration - which can be defined as factors in the chain of causation that directly induce migration - has been declining in academic writing. However, it is notable that the notion of root causes (FAO, 2016a) has gained influence in policy circles. Indeed, in response to the 2015 migration and refugee crisis, European governments stressed the need to address migration challenges by tackling the root causes, often adopting a narrow approach as addressing the causes of forced migration in order to curb migratory flows (Knoll and Sherriff, 2017). However, such a strategy is questionable (Carling and Talleraas, 2016; Clemens, 2014) partly because it underestimates the role of individual aspirations which tend to rise with socioeconomic development. The risk of such an approach is to support the instrumentalization of development cooperation for security purposes, often attaching a negative connotation to migration instead of thinking about the role and contribution of migration to economic development and structural transformation (Knoll et al., 2017).

The rise of drivers instead of determinants and causes in the migration literature in the early 2000s goes along with the growing interest in environmental effects on migration, especially climate change (Black et al., 2011). It has progressively become clear from various case studies that environmental change could deeply shape migration. Yet, given the complex interactions within a variety of socioeconomic contexts, it seemed excessive to advance that climate change is a determinant of migration and the concept of drivers offers a better analytical option. They can be defined as factors that induce, orient and sustain migration (Van Hear et al., 2012, 2017), and that can be external or internal to the household.

${ }^{12}$ Additional definitions are provided in annex 6. 
They are forces that influence both decisions to migrate and migration processes. Compared to determinants and causes of migration, drivers might also have gained from tensions about causality in migration studies. The shift from causes and determinants to drivers allows for a better understanding of the complex dynamics that shape migration (Carling and Collins, 2017).

\subsection{A critical literature review of past and present drivers of migration}

Migration is a multidisciplinary field of study where research is strongly compartmentalized between and within disciplines, with limited analytical and methodological work across boundaries, failing to settle an agreed body of knowledge for the understanding of the migratory process. As a result, theories on the drivers of migration present core limitations and related broad empirical biases. Acknowledging that migration connects to all aspects of social existence, and thus requires an interdisciplinary approach, new theoretical advances have started to address these limits.

\subsubsection{Conventional theoretical approaches: limitations and empirical biases}

Conventional approaches of the drivers of migration mostly arise from the fields of development studies, economics, sociology and human geography. The following development focuses on the most prominent approaches and theories.

\section{a. Conventional theories and their limitations}

Since Ravenstein's laws enounced more than one century ago (Ravenstein, 1885), the search for explanatory factors has been a long-standing feature of migration theories. However, in development studies and economics, migration was mostly considered from the 1960 s only. The debate originally focused on causes and effects of migration independently and, more generally, tended to separate determinants and effects of migration from broader processes of socio-economic change (de Haas, 2010a). This position meets determinist approaches of migration by neoclassical as well as structuralist theories which typically frame migration as a response to asymmetries and inequality, implying that a sedentary global society would be a condition for balance and equality (IMI ESF, 2011).

In standard neoclassical theory, the explanation of migration has focused on disparities in economic conditions between places of origin and places of destination. Push and pull models in classical literature suggested that migrants (as individuals) were pushed by low incomes in their countries or regions of origin and pulled by better prospects in more affluent areas (Lee, 1966; Harris and Todaro, 1970). General critics of this approach have argued that push-pull models basically present lists of factors which lack a framework to bring them together in an explanatory system (Skeldon, 1990). The static nature of such models is a further limitation. In conceptualising migration as a single action rather than a process, push-pull models do not account for shifting motivations, altered circumstances or decisions within the migration process itself (de Haas, 2011b).

At the end of the 1980s, neoclassical theory extended its scope to institutional dimensions. Other explanations for migration were then sought at the micro-level, such as in household decision-making. The New Economics of Labour Migration (NELM) theory conceptualises migration as a collective household strategy to mitigate livelihood risks and to overcome market constraints, rather than an individual matter in response to income differentials (Stark, 1991). However, due to its micro-level focus, NELM neither includes historical contextual factors, nor sets a clear connection between macrostructural factors and household decision-making, because it does not specify hypotheses about the roles played by governments, policies, labour markets and power asymmetries (de Haas, 2011b). 
By contrast, within the general paradigm of structural history developed in sociology, Marxist, dependency and world systems theories (Wallerstein, 1974; Massey et al., 1998) picture migration as the effect of the expansion of global capitalism and the related marginalization and relocation of rural population, with no other option than joining the urban proletariat (de Haas, 2010b). These approaches are strongly questioned for being deductive and deterministic, with associated representation of individuals as passive victims of economic macro-forces. Individual migrants have limited agency and are supposed to make irrational choices. Further, like neoclassical ones, structural historical approaches focus on rural-urban migration, assuming the integration of migrants at destination, and the disruption of socioeconomic linkages with places of origin.

\section{b. Common biases of empirical migration studies}

These long standing and still dominant conventional theories about migration drivers have resulted into broad and now well-known biases that are still arising from the empirical literature. Four main critical woven biases related to various conceptual issues as well as data limitation can be mentioned: the focus on economic drivers, the national scale of analyses, the tendency to examine drivers of specific patterns, and the critical challenge of causality.

\section{The focus on economic drivers}

Conventional theories focus on how income and wage levels, and to a lesser extent, income inequalities, affect migration processes. While they might differ in their specification, they share a focus on economic differentials as the main driver of migration (IMI, ESF, 2011). But non-economic and unobservable factors also strongly influence migration decision (de Haas, 2011b; Mora and Taylor, 2006). Migration research tends to ignore the fact that, at the macro-level, migration processes are driven by a range of economic and non-economic factors. Similarly, at the micro-level, migrants are motivated by a combination of multiple, interconnected but distinct socioeconomic, cultural and political factors (de Haas, 2011b; Ruyssen and Rayp, 2013). For instance, gender differences in access to - and forms of - migration in Africa have been poorly documented although they are core dimensions of migration decision (Chort et al., 2018). A case study from Rwanda also points three critical factors in rural to urban youth migration: availability of social services in rural areas, which is likely to deter youths from migration, and presumed stable jobs in cities coupled with an inauspicious social environment in rural areas are likely to incentive migration (Mutandwa et al., 2011). Hence, understanding the role of non-economic and unobservable factors in driving migration and in mediating its impacts is a major research gap.

\section{National scale analyses}

A second issue relates to the geographical scale of analysis. Beyond the fact that little is still known about the determinants of South-South migration (Ruyssen and Rayp, 2013), there is a tendency to examine and theorise migration at national level, as the dominant unit of analysis in migration studies. However, national level is often not the relevant scale given the context specificities of migration drivers. This raises the question of the relevant spatial level, beyond the nation-state, for analysing migration determinants: the region, bilateral migration corridors, or trans-multinational networks (IMI ESF, 2011)? In relation with the later, there is a general bias towards examining (international) migration from a receiving country perspective, as opposed to sending countries (de Haas, 2011b). This bias towards the receiving country in migration research stresses the need to develop a specific understanding of drivers of migration processes at different levels in countries of origin (de Haas and Vezzoli, 2011). For instance, emigration policies implemented by sending states, or social security and welfare spending, are examples of potentially critical migration drivers (IMI ESF, 2011). Applied to rural-urban migration, access to infrastructure and services in sending rural areas are also often key migration drivers. 
Migrants' journeys are increasingly diverse, complex and fragmented. Research on the dynamics of migration is very distinctly split, with limited connection, between studies on internal and on international migration, characterised by different concepts and methods (King and Skeldon, 2010). In particular, there is limited awareness about two-stage migration patterns, whereby journeys encompass internal - and - international migration. Further, there is still limited knowledge about the different nature of drivers according to migration patterns (international/internal/mixed; short/long term). This constitute a strong bias because of the selectivity of the migration process, drivers of migration being likely to differ across locations (Mora and Taylor, 2006). For instance, Herrera and Sahn (2013) exemplify the diverse nature and drivers of internal mobility, by differentiating between temporary and permanent migrants, their rural or urban origins and destinations. In short, the lack of a comprehensive framework of migratory patterns, which integrates more or less complex step-wise and circular trajectories, is a strong limitation for analysing the determinants of migration (Castagnone, 2011).

\section{The endogeneity issue}

Lastly, quantitative migration studies are not only challenged by data availability and limitation but also by the endogeneity problem that may be created by reverse causality. The latter refers to the recursive nature of the determinants and effects of migration decisions in situations where migrants maintain ties with their area of origin in various ways, including remittances (Mckenzie and Rapoport, 2007; SabatesWheeler et al., 2008). The economic status of a household and other migration factors that might cause migration decisions are then shaped by the migration itself (Sabates-Wheeler et al., 2008; de Haas, 2010a). According to Bakewell (2011), scholars in migration studies seem to have progressively shifted away from methods that attempt to investigate causal mechanisms, a core reason (in addition to data issues) being that assessing causality entails to strongly reduce the complexity of migration processes. Particularly, this search for causality has led many empirical studies to consider in fine a simple, deterministic monocausal linear relation between a driver and a migration pattern. For instance, the causal connections and interactions of factors within the food security-migration nexus is often reduced to a proportional relation that can be addressed through policies related to agriculture and rural development. With such oversimplification, the view of policy makers about the food security-migration nexus is often naive and focuses on simplistic - if not inappropriate - solutions (Knoll et al.,2017).

As a result, there is still a limited understanding of forces driving migration. Limited push-pull and gravity models continue to likely omit crucial non-economic and socio-political factors, including in the sending-country or area. Despite the consensus that "macro-contextual economic and political factors and meso-level factors such as networks all play some role, there is no agreement on their relative weight and mutual interaction" (de Haas, 2011b). Therefore, the challenge is to establish when and why some drivers are more important than others, which combinations are more powerful than others, and which of them are more susceptible to change through external intervention in order to support more inclusive societies (Castles, 2010; Van Hear et al., 2017).

\subsubsection{Emerging comprehensive approaches}

Alternative research already started to set the base for a more comprehensive approach of the drivers of migration, stating that migration theory needs to include the multiple components of migration, the way migration fits in social relations, obligations, power relations and politics, as well as related to economic constraints that are all the "realities of displacement" (Carling and Collins, 2017). 


\section{a. The common ground: migration as part of social transformation}

Recent efforts to rethink migration and the drivers of migration theory are often grounded in Castles' understanding of migration from a social transformation perspective (Castles, 2010). He argues thatsignificant progress can arise from re-embedding migration research in a more general approach of society, linking it to broader theories of social change across different social disciplines. A conceptual framework for migration studies should take social transformation as its core component, in order to ease the understanding of complexity, interconnectedness, variability, contextuality and multi-level mediations of migratory processes in the context of fast global change. This means examining the links between social transformation and human mobility at various socio-spatial levels, while trying to understand how human agency can shape answers to structural factors (Castles, 2010).

Another development into rethinking the drivers of migration involves efforts to take time more seriously as a constitutive feature of migration (Cwerner, 2001). In conventional thinking, time is often interpreted as linear and can be split into pre-migration, migration and then either settlement or return. The result has been an emphasis on what is identified as 'standard' temporal practices. With regard to migration drivers, it led to codify standard patterns of time-bound migration. Recent research focuses on migration adopting a continuous time perspective: aspiration is not only socially situated but also future-oriented (Carling and Schewel, 2017); the "on-going-ness of migratory processes" is acknowledged (Erdal and Oeppen, 2017 in Carling and Collins, 2017); opportunities and obstacles can start but also end migratory pathways (Collins, 2017); and even mediating drivers are considered as part of sustaining and shaping migratory flows (Van Hear et al., 2017).

\section{b. Integrating micro, meso and macro levels: bringing in capabilities, aspiration and structures}

A conceptual framework at the level of the individual and household that is centred around 'capabilities' and 'aspirations' may facilitate the understanding of why some people move and others not, and also contribute to the development of micro-level migration theories (de Haas, 2011b; Carling and Collin, 2017). Such a framework would provide a conceptual basis to link to meso- and macro-level forces in order to produce a more integrated view of migration drivers. As a result, researchers could analyse the extent to which meso- and macro-level factors affect migrants' capabilities and aspirations. Crucially, a capabilities and aspirations theory of migration considers human agency as central in migration processes: it positions migration as an action towards realising individual livelihood goals, rather than a passive or predictable reaction to structural asymmetries and spatial opportunity differentials (de Haas, 2011b).

To connect the capabilities and aspirations of individual migrants to more structural, macro-level determinants of migration, Willekens (2011) offers a conceptual framework derived from complexity science which shows how the interactions between agents (who have attributes and aspirations that change over time), between agents and structures, and the feedback mechanisms they generate, give rise to migration patterns and systems.

By analysing the role of meso-structures in migration processes, like the development of networks and migration systems, meso-level theories do not intend to offer a broad understanding of drivers of migration, but to provide a core link between individual and structural approaches (Faist, 1997). Socioanthropology and human geography research have underlined the importance of linkages, networks and culture in migration processes and how they result in powerful institutions (Boyd, 1989; Skeldon, 1990; Massey et al., 1993). Research also evidenced feedback mechanisms which explain why, once started, migration processes tend to become partly self-perpetuating, leading to the formation of migrant networks and migration systems (Castles and Miller, 2009; Mabogunje, 1970; Massey, 1990; Massey et al., 1998). 
Such feedback loops provide a powerful example of the interplay between agency and structure. They show how migrants create meso-level structures, such as networks that have a (feedback) effect in reinforcing migration between particular places and countries. These networks fuel counter-flows of ideas and information (Mabogunje, 1970), as well as they reduce the costs and risks of migration (Massey et al., 1998), and contribute to the adaptation to structural constraints such as high travel costs and immigration policies. However, theories related to these 'internal dynamics' of migration processes also present some major faults. Particularly, the usual focus on migrants' networks goes with a neglect of other feedback dynamics that run through the impact of migration on sending and receiving countries and places (IMI ESF, 2011). This is the case, for instance, of broader rural-urban linkages resulting from migration networks (e.g. such as productive and non-productive investments allowed by migrants' remittances).

Similarly, for Carling and Talleras (2016), drivers of migration are multifaceted and often interact in a complex way leading to migration aspirations and decisions to migrate. The outcome of such decisions is mediated by migration infrastructure ${ }^{13}$ at a systemic level and capabilities at individual level (Xiang and Lindquist, 2014; Andersson, 2014).

\section{c. Multi-dimensionality}

Despite the need to integrate non-economic factors in migration decisions and processes, few research work offers a systematic and more exhaustive vision of the drivers of migration. In this way, Bilsborrow (2002), in a study on the broad linkages between migration, population change and rural environment, gives insights on a broader picture highlighting the diversity of the drivers of migration, notably the specifics of the drivers of rural migration in developing countries. According to his model connecting rural household decision-making about migration with the rural environment, households continuously evaluate conditions in the place of origin and elsewhere, to determine how to live or cope in difficult times, or whether to move to improve their standard of living. More important, he points the crucial roles played by contextual factors as determinants of rural households' decisions about migration. These factors include: local and national natural-resource endowments; social and economic infrastructure; national and local government policies that determine land ownership and access to land; environmental policies and set-asides for protected areas; road construction; and the regulation (or lack) of extractive activities. They establish the physical context and rules of the game for household responses to demographic pressure and environmental degradation. In sum, as rural livelihoods highly rely on natural resources, Bilsborrow's work points the importance of environmental drivers of rural migration (but also the influence of environmental stress on the drivers of migration) within other drivers such as specific sectoral or macro policies.

Ryussen and Rayp (2013) present a comprehensive human capital model of migration applied to SSA which is not particular to rural migration. This model not only integrates the economic drivers of migration but also the specific demographic, socio-political and environmental factors of countries of origin and destination, as well as characteristics of the regional context. Their work furthermore includes network effects and natural, cultural and infrastructure factors facilitating or not migrant flows to the host country, such as geography, transport, communication and psychological costs of migration. Such a model allows the assessment of the relative importance of different factors driving migration patterns. While evidencing that SSA's migration results from a multidimensional set of factors, their findings suggests that migration is to a large extent driven by income differences, networks and geographical proximity.

Black et al. (2011) provide a more comprehensive conceptual framework of the drivers of migration. Conceived as a pentagon of thematically classified drivers, they group migration drivers into five categories: social, political, economic, environmental and demographic.

${ }^{13}$ For Carling and Talleras (2016) the concept of migration infrastructure was developed by Xiang \& J. Lindquist (2014) who argue that "it is not migrants who migrate, but rather constellations consisting of migrants and non-migrants, of human and non-human actors". This is embedded within five dimensions: "the commercial (brokers, smugglers), the regulatory (state and procedures), the technological, the humanitarian (NGOs, international organisations), and the social (migrant networks)". 
It is the existence of spatial and temporal variability in one or more of these five dimensions that creates the conditions (or drivers) for migration, allowing them also to interact or overlap in different ways in different places. For these authors, this is similar to a combination of push and pull factors, but it allows complex forces to act through systems of influence. Whether migration occurs or not in a place also depends on a series of intervening institutional factors. Individual and household characteristics also influence migration decisions. This framework raises a second crucial question: whether environmental change is likely to alter the effect of these drivers. This conceptualisation "seeks to focus attention away from the idea that environmental change directly causes migration, towards an understanding of the broader drivers of migration, and how these might act in different and inter-linked ways to environmental change" (Black et al., 2011). It is conceivable that environmental change might actually weaken the effect of a migration driver.

Finally, Van Hear et al. (2017), building from Black et al. (2011), raise the level of abstraction and look at ways in which drivers may be conceptualised and identified at different levels, and then specify a framework for understanding them, both singly and in interlocking complexes (cf. 2.3). They understand decisions to migrate -or not- and the inception of broad patterns of migration as the outcome of interplay between these socio-economic structures and agency. In any migration pattern, several driver complexes may interconnect to shape the ultimate direction and nature of movement.

Together, these approaches make important contributions to advancing the understanding of migration. First, they reveal the conceptual promise of re-engaging drivers of migration in ways that consider migrants agency and structural conditions as inter-connected systems. Second, they build on criticisms of dichotomies in migration by reassessing divisions between internal and international migration, migrants and non-migrants, and the linear timing of decision-movement-outcome. Third, by recognizing the openness of aspiration in migration, they build on social sciences' growing interest for foresight thinking and, more generally, the future (Carling and Collins, 2017).

\subsection{A critical synthesis of futures studies on migration}

In that perspective, this section presents a synthesis about what recent futures studies (forecast/ projection, foresight/scenario, and other studies), identified according to several key criteria (see methodology section 1.2.1), say about the futures of rural migration in SSA. It intends to provide emerging approaches about the drivers of migration.

\subsubsection{Existing studies on migration in Africa}

37 studies corresponding to the relevance criteria were identified. Results are presented in Annex 4 in three tables for forecasting, foresight and other studies, using the Social, Technical, Economic, Environmental, Political (STEEP) classification to qualify the dimension of the identified drivers. ${ }^{14}$ The results displayed in Table 3 show that the number of studies matching the search criteria is rather limited and it was not possible to identify any highly relevant futures study, indicating a very weak futures literature about rural migration in SSA. It is also worth noting that forecasting studies are out-numbered by foresight studies and other analytical studies.

\footnotetext{
${ }^{14}$ The STEEP (Social, Technical, Economic, Environmental, Political) classification is commonly used in futures studies (Saritas and Smith, 2011; Slaughter, 2008; van Notten, 2006).
} 
Table 3: Main features of 37 identified futures studies

\begin{tabular}{|c|c|c|}
\hline Forecasting studies & Foresight studies & Other analytical studies \\
\hline $\begin{array}{l}8 \text { studies identified. } 2 \text { are rated } \\
++, 4+, \text { and } 2+-\end{array}$ & $\begin{array}{l}17 \text { studies identified. } 5 \text { are } \\
\text { rated }++, 8+\text {, and } 4+-\end{array}$ & $\begin{array}{l}12 \text { studies identified, } 5 \text { are rated } \\
++, 1+\text { and } 6+-.\end{array}$ \\
\hline $\begin{array}{l}\text { The scale of these studies } \\
\text { spans from global to regional } \\
\text { and national levels. While all } \\
\text { five dimensions are present } \\
\text { across the studies, the } \\
\text { economic dimension prevails } \\
\text { being present in all of them, } \\
\text { followed by the social and } \\
\text { political dimensions, then } \\
\text { the environmental and finally } \\
\text { technological dimension. } \\
\text { Economic asymmetries are } \\
\text { identified as a recurrent driver } \\
\text { followed by demography. }\end{array}$ & $\begin{array}{l}\text { Regional and global scenarios } \\
\text { prevail, with only one case } \\
\text { of national / intra-national } \\
\text { scenarios. Economic and } \\
\text { political drivers are the most } \\
\text { often cited (12 and } 11 \text { times), } \\
\text { then environmental (7), social } \\
\text { (6) and technological (5) } \\
\text { dimensions. Global economic } \\
\text { asymmetries, local economic } \\
\text { situation and income gaps are } \\
\text { the main economic drivers. } \\
\text { Political situation and migration } \\
\text { policies are recurrent drivers } \\
\text { of the political dimension. } \\
\text { Climate change and variability } \\
\text { are referred to as broad } \\
\text { environmental drivers, while } \\
\text { water, soil and energy are more } \\
\text { specific issues. Technological } \\
\text { innovation is a broad driver with } \\
\text { ICT and farm structures being } \\
\text { more specific. }\end{array}$ & $\begin{array}{l}\text { Global and regional studies } \\
\text { prevail, with only one national } \\
\text { study. Economic drivers } \\
\text { are most frequently cited, } \\
\text { particularly employment } \\
\text { opportunities and economic } \\
\text { differentials including poverty } \\
\text { and inequity. Environmental } \\
\text { drivers refer to climate change } \\
\text { and more specifically to water, } \\
\text { land and ecosystems. Migration } \\
\text { policies, political situation, } \\
\text { geopolitics and conflicts and } \\
\text { crises characterize the political } \\
\text { dimension. The social dimension } \\
\text { is associated with demography } \\
\text { and social links. Farm structure } \\
\text { and digital gaps correspond to } \\
\text { the technological dimension. }\end{array}$ \\
\hline
\end{tabular}

This limited relevance of the futures studies literature can be explained by the fact that migration is the most unpredictable demographic factor at least for mid-term exploration of the future (10 to 20 years). All migration components (type, direction, intensity, duration, even existence) are highly volatile and the potential effect (direction and intensity of change) of a specific driver on migration is not always clear. In a study dedicated to the effect of climate change on migration, Black et al. (2008) concluded that “... we are a long way away from predicting with any degree of certainty what the migration consequences of climate change might be over the next 40-50 years".

Furthermore, drivers do not operate in isolation. Echoing Black et al. (2011) and Van Hear et al. (2017) frameworks, the way the evolution of one driver affects migration depends on how other drivers will also evolve (RMMS and IMI, 2012). As a result, while there is substantial empirical knowledge about what can induce, orient and sustain migration, it is almost impossible to predict what will happen locally. In addition, strong criticism about forecasting migration exists: "Most of the predictions were affected by the same flaws and biases as were current estimates: a weak or inexistent methodology, and a tendency to use the numbers in order to raise awareness" (Gemenne, 2011). Migration is very volatile and difficult to predict as it is sensitive to shocks of various nature such as economic crises, military conflicts, policy changes, themselves highly unpredictable (Bijak et al., 2015).

Yet, it is possible to unveil, explore and understand uncertainties related to migration and use that foreknowledge to guide actions towards desirable migration futures. The construction of future scenarios is an alternative approach to forecasting (OECD, 2016). 


\subsubsection{Drivers}

A detailed analysis of the most relevant studies according to the STEEP classification provides the following insights regarding each of these dimensions.

Economic drivers are frequently associated with an economic differential between areas of origin and areas of destination. Migration is related to inequalities and tends to occur from places with less attractive economic local conditions, regarding particularly poverty, income levels and opportunities, employment and labour market conditions - especially for the youth, towards emerging more attractive areas abroad or within the country (to urban areas).

Political drivers regroup a cluster that could be called global political drivers (global governance) and a cluster related to national political drivers (national governance). The latter includes the capacity of the state, the political system, national migration policies and investment policies. The future states of this cluster would condition the aspirations of people to move or stay where they live. The global cluster is linked to the global political situation (global and regional governance regimes, geopolitics, migration policies of destination countries). It shapes not only the potential destination of migrants but also the type and intensity of competition between migrants towards countries of destination. War and conflicts, both national and global, bring even higher levels of uncertainty in migration patterns.

Social drivers include a demographic dimension (growth of population, natural population growth in the cities) that, associated with social development levels, the state of institutions in areas of origin and the level of food insecurity, would be shaping the intensity of migration. While historical and linguistic links and social receptivity are seen as major determinants of the direction of migration, individual characteristics such as education, network connection, and the capability to migrate (associated also with poverty and income levels) are seen as shaping trends about who migrates.

Environmental drivers include the generic terminology of climate change and climate variability. Beyond these terms, the studies stress the importance of energy (type and access) and natural resources, particularly water availability, soil quality and population/resource ratio.

Technical drivers include broad terms such as technical progress and innovation, technical change, scientific and technical innovation. ICT is highlighted and studies with a focus on agriculture see the technical means of production and the level of farm outputs as determinant factors.

The drivers of future migration in SSA are not only multiple across economic, social, political, environmental and technical dimensions, they are also interconnected as most studies refer to two or more dimensions. As highlighted in the above theoretical review (section 2.1), the way they are connected is a source of uncertainty. Climate variability and climatic hazards for example would be affecting differently potential migration patterns depending on the economic, social and political conditions where these events would take place. Similarly, network connection, linguistic and historical links can be connected with the social receptivity of the migrants and migration policies in destination countries in opposite ways.

\subsubsection{Future patterns of rural migration}

Drawing from a study on megatrends of human settlement taking into consideration the potential effect of climate change and the evolution of human settlement (Valsson and Ulfarsson, 2012), it is possible to identify plausible global population moves in SSA for the next 30 years as indicated in Table 4 below.

These global alternative futures were combined with another anticipatory study exploring seven plausible scenarios for rural areas (Bourgeois, 2015). It resulted in the development of three anticipatory narratives regarding SSA's rural migration based on scenarios that could become dominant in each world order. ${ }^{15}$

${ }^{15}$ The transformation scenario was not included, as it would require a time horizon beyond 2050. 
Table 4: Global patterns of migration and potential implications for SSA

\begin{tabular}{|c|c|c|}
\hline Patterns* & Reason* & SSA patterns ${ }^{\star *}$ \\
\hline To the poles & $\begin{array}{l}\text { Rising heat, lack of water, } \\
\text { overpopulation, dwindling resources, } \\
\text { and pollution in the central tropical } \\
\text { areas of the globe push away people } \\
\text { towards more temperate areas }\end{array}$ & $\begin{array}{l}\text { Under these circumstances SSA } \\
\text { population would be expected } \\
\text { to move towards South Africa, } \\
\text { Botswana, Zimbabwe }\end{array}$ \\
\hline $\begin{array}{l}\text { To coasts in warm } \\
\text { regions }\end{array}$ & $\begin{array}{l}\text { Cooler coastal areas in very warm and } \\
\text { warming countries. Coasts pull people } \\
\text { as they offer different types of climate. } \\
\text { Increasingly hot and often dry interiors } \\
\text { in already very warm central regions } \\
\text { push away human activity and people } \\
\text { from the interiors }\end{array}$ & $\begin{array}{l}\text { In many sub-Saharan countries, } \\
\text { coastal areas are not particularly } \\
\text { cooler and would be warming too. } \\
\text { The effect on population would } \\
\text { be to draw people mostly towards } \\
\text { coastal areas of Southern Africa }\end{array}$ \\
\hline $\begin{array}{l}\text { To higher areas in } \\
\text { warming regions }\end{array}$ & $\begin{array}{l}\text { The warming of colder high interiors } \\
\text { of warm countries would draw more } \\
\text { activity and people. A reverse push } \\
\text { from some coastal areas due to } \\
\text { overpopulation or warmer conditions } \\
\text { could accompany this move }\end{array}$ & $\begin{array}{l}\text { This could induce population } \\
\text { movements towards central } \\
\text { areas of Southern Africa and } \\
\text { East Africa highlands }\end{array}$ \\
\hline $\begin{array}{l}\text { Towards new } \\
\text { prospering centres of } \\
\text { human activity }\end{array}$ & $\begin{array}{l}\text { New/emerging prospering centres of } \\
\text { human settlement increasingly attract } \\
\text { people and activity, while others } \\
\text { decline lacking opportunities to thrive }\end{array}$ & $\begin{array}{l}\text { This would lead population } \\
\text { moving towards attractive } \\
\text { existing capital cities, new } \\
\text { economic corridorsandemerging } \\
\text { economies such as Gauteng and } \\
\text { Western Cape provinces in South } \\
\text { Africa, the East African corridor, } \\
\text { or the coastal West African } \\
\text { conurbation }\end{array}$ \\
\hline
\end{tabular}

Source: $\left(^{*}\right)$ Valsson and Ularfsson 2012; $\left(^{* *}\right)$ - Adapted by the authors

The clusters of economic and political determinants previously identified indicate the importance of the future state of the global world order regarding migration. A discussion of the futures of SSA's rural migration needs therefore to take into consideration alternative future worlds. For this purpose, it is possible to refer to Dator's seminal anticipatory work on global alternative futures which proposes four alternatives (Dator, 2009):

- Continued growth: the pursuit of current trends where continued economic growth is seen as the driver of development and the only pathway;

- Discipline: refocus economy and society on survival and fair distribution, and not on continued economic growth;

- Collapse: economic, environmental, resource, moral, or ideological collapse possibly leading to extinction or at least to a significantly lower level of wellbeing/development;

- Transformation: the transformation of all life, including humanity from its present form into a new "post human" form, on an entirely artificial Earth. 
These narratives, which are presented in Annex 5, indicate that prospects for massive flows of rural out-migration from SSA are limited. None of them would offer options that would significantly improve the living conditions of migrants. This anticipated trend is consistent with observations highlighting that only higher educated, highly qualified and, to some extent, semi-skilled migrants would find labour opportunities through intercontinental migration (OECD, 2009; World Bank, 2009). Rural SSA's migrants, unless significant local development with regard to their education, skills and assets, would be among the most disadvantaged.

Future SSA rural migration is drawn to happen within the same country or within the same region, towards few areas which could benefit from climate change (e.g. new cropland) or towards emerging economies and urban centres. Existing social networks, language similarities and diaspora links will play a major role in shaping the preference and direction of the migrants, a role further reinforced by advances in technological connectivity.

Unless societal choices are made that would enable SSA's rural people to be in a situation to freely choose and have the capability to migrate, it is important to pay attention to options where SSA rural population would not have to migrate. The discipline scenario offers clues on what this would mean: a refocus on balanced territorial development, offering decent livelihoods and fair access and rights to use the resources.

A complex geography of migration in SSA is emerging from this literature review and analysis. ${ }^{16}$ The futures of rural migration in SSA is shaped by a multi-dimensional combination of drivers including crucial variables such as the size of the rural population, the location and occurrence of extreme weather events (droughts and floods), the level of poverty and food insecurity, access to decent job opportunities, the quality of governance, and the attractiveness of human habitats. In this way, futures studies highlight both the specificity of the drivers of rural migration with regard to environmental factors, demography or particular sectoral policies, and the relevance of emerging comprehensive approaches in conceiving drivers of migration as multifaceted and multidimensional, mostly acting in complex combinations (see 2.1.2). Rural migrants will go to African rural or urban safe havens that provide peace, stability, decent lives and livelihoods. The combinations of drivers at play are locally specific, making it impossible to predict where exactly these places will be found, but it is possible to anticipate what could happen and act in consequence. There is a risk of a massive convergence of migration flows towards a limited number of safe havens. Once their maximum absorption capacity is exceeded, their social receptivity to migrants will fade, leading to conflicts that will threaten their existence, possibly turning them into hostile places. More migrants would likely move and look for other options, returning to their places of origin or moving to less-populated areas with possibly limited opportunities and harsher natural conditions.

\subsection{The proposed framework for analysing the drivers of rural migration}

To avoid the sedentary bias of the mainstream political discourse, which portrays migration as a problem to be fixed (Bakewell, 2007), and in line with Castles (2010), policy debates about migration should not be based on the normative objective of finding ways of helping people to stay home. Instead, based on a better understanding of the processes underway with reference to the existing literature, they should postulate that migration is a normal part of social relations and research shoul dcontinue to help analyse the drivers and dynamics of migration, as a part of complex and diverse processes of societal change. If a normative goal exists, it should not be to belittle migration but to find ways so that it could take place under conditions of equality and respect for human rights.

\footnotetext{
${ }^{16}$ See Atlas FAO-Cirad, spread 12 (Bourgeois, 2017) for a representation of these dynamics.
} 
Although it is elusive to look for a one-size-fits-all theory explaining migration at all places and at all times, there is certainly room for advancing theories on migration and how they mutually connect to social and economic change (IMI ESF, 2011).

Drawing from interdisciplinary and comprehensive approaches based on Black et al. (2011) and Van Hear et al. (2017), as well as learnings from futures studies, this working paper proposes a conceptual framework for generating improved insights into the nature and combination of the drivers of migration. This framework is intended to help unravelling the mechanisms at stake in the migration process, shaping rural migration patterns in the diversity of African contexts, and their linkages with rural socio-economic transformation. Figure 1 adapted from Black et al. (2011) synthetizes the proposed framework of drivers of rural migration and related migration patterns.

First, taking stock of studies on rural migration that identify a diversity of factors which influencing migration decisions and processes, the framework integrates both economic and non-economic drivers of rural migration, with reference to Black et al. (2011) broad classification in five dimensions (environmental, political, economic, socio cultural and demographic). Following Van Hear et al. (2012, 2017), in each of these dimensions drivers can have different functions ${ }^{17}$ that shape the conditions within which people make the decision whether to migrate or not.

Fig 1: The multifaceted drivers of rural migration

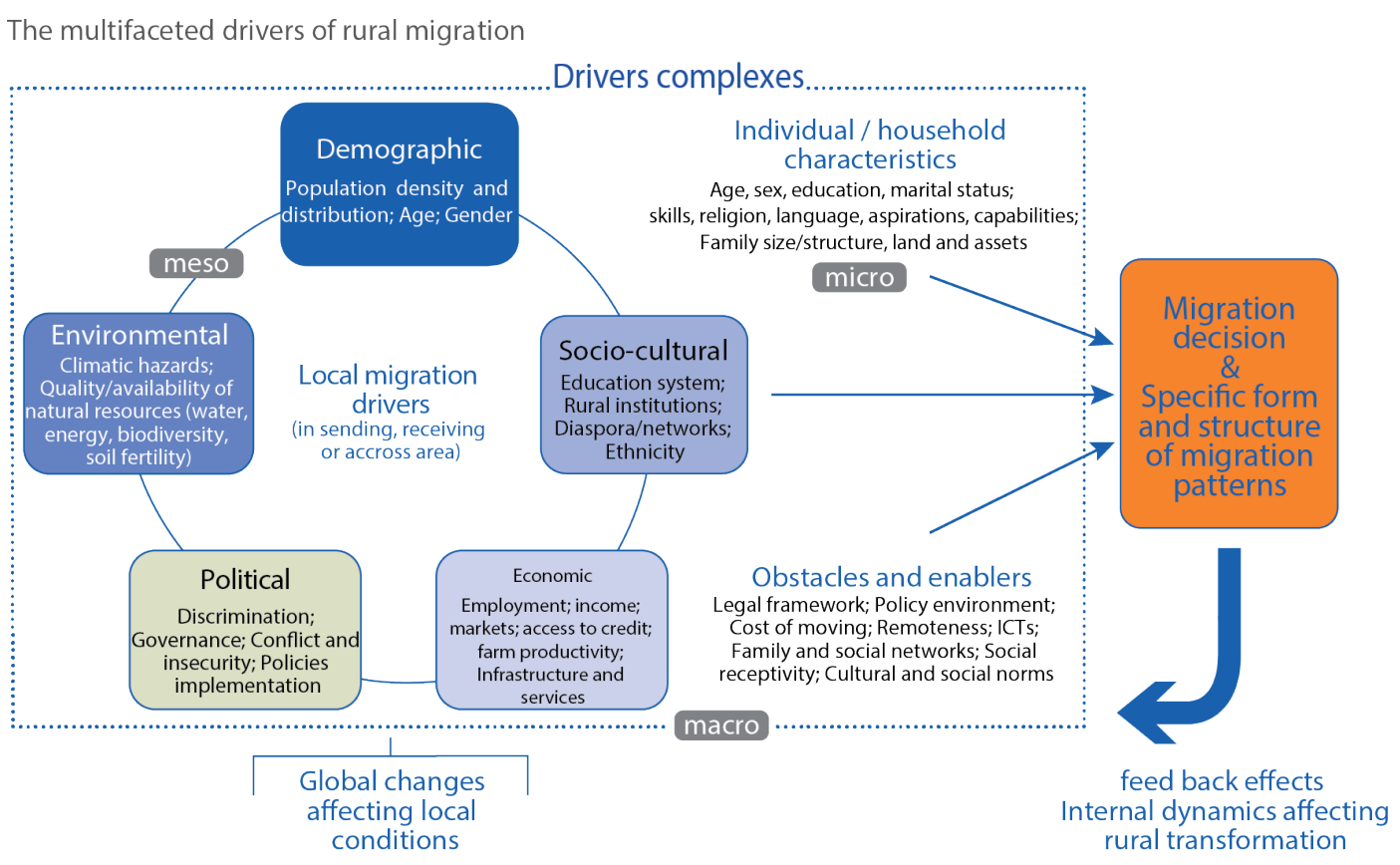

Source: Atlas FAO-Cirad - Mercandalli, Losch, Rapone, Bourgeois and Khalil, 2017.

Second, the proposed framework is a recognition that a comprehensive examination of the drivers of migration should bridge micro, meso and macro levels to achieve a better understanding of migration processes. Thus, drivers can be rooted either: at individual and household level (micro); at global level (macro), international or national; and at local to sub-regional level (meso). They can be related to a receiving or sending area (a community or a region), or work across these locations, possibly transnationally.

Drivers may play at short or long term depending on the nature of their timescales. Hence, migration processes and outcomes are context specific; they may even vary within a specific place.

\footnotetext{
${ }^{17}$ This means that for instance, in a given context, a particular economic or political driver might have a range of different functions in the chain of causation that induce, orient and sustain migration. Van Hear et al (2017) identifies five functions: predisposing, proximate, precipitating and intervening factors that shaped what is termed 'migration orders'.
} 
Third, the framework considers that the many drivers which initiate, orient and sustain migration at micro, meso and macro levels do not operate in isolation. Instead, drivers work in combination, and their effects are intertwined in what can be called drivers complexes. However, by contrast to Van Hear et al. (2017), who restrict the use of drivers complexes to more external material forces influencing mobility, the approach proposed in this paper follows Benson and O'Reilly (2009) and includes aspirations as driving people's migration.

The concept of drivers complex helps identifying specific multi-level and multi-dimensional sets of drivers of migration; it improves our knowledge on migration processes and the specific form and structure of migration patterns. For any migration pattern, several drivers complexes may interconnect in shaping the direction and nature of people's mobility.

Fourth, to achieve a precise understanding of factors driving migration decisions and processes and the way they interact (in shaping migration patterns), the proposed framework includes the critical issue of causality and feedback effects. ${ }^{18}$ Beyond identifying migration's key drivers and how they may be configured, the framework points out, in certain contexts, what makes some drivers more prominent than others. As such, it establishes when and why some drivers matter more than others (Castles, 2010; Van Hear et al., 2017). Cognizant that migration is a constituent of broader social and economic change, this comprehensive framework of migration's drivers grants that the impacts of migration in origin and destination societies reciprocally affect the conditions that drive migration. Through these recursive loops, impacts are, or can become, migration drivers on their own.

Fifth, and related to the previous point, a drivers complex also considers the possibly simultaneous selfsustaining and self-undermining internal dynamics supported by migration processes. This is illustrated in situations where migrants maintain ties with their area of origin through consumption, investment, or social remittances (Levitt, 2001). This type of dynamics increases socioeconomic and spatial linkages with potential impacts on rural and structural change simultaneously facilitated by new livelihoods strategies shaped by mobility (Mercandalli, 2014, 2015). In such situations, migration can be considered as a migration structure and appears as a mechanism of adaptation and resilience in a context of multiform mutations (Delaunay et al., 2016). This view differs from migration conceived as a disruptive element for areas of origin developed in structuralist theories.

The drivers complex framework must be considered as a proposal for future heuristic in-depth research and this working paper cannot develop and test all its dimensions. Indeed, according to the methodology adopted in this work, the following sections illustrate local drivers of migration in places of origin and destination, and existing global changes, obstacles and enablers in the migration process. The individual and household characteristics are only partially addressed through quantitative analyses (cf. 3.3 and 4.1). A complete picture of the on-going migration processes would require more empirical data from fieldwork and surveys which barely exist, in order to feed more dedicated datasets and engage in further quantitative analyses. This additional research investment to be develop in the future would allow to take into account individual aspirations and causality, just to mention these two core elements, and the way drivers complexes shape a diversity of migration patterns (internal and international, short and long term, and for specific socio economic groups, economic sectors or places).

\footnotetext{
${ }^{18}$ Aware that migration is an integral part of socioeconomic change, which makes analytically difficult to disentangle 'cause' and 'effect' and to set direct causation, research on causality has lessen. Further, defining causal mechanisms may lead to the tentative setting of 'laws' explaining migration which can only be ill-suited when applied to different migration contexts (IMI ESF, 2011).
} 


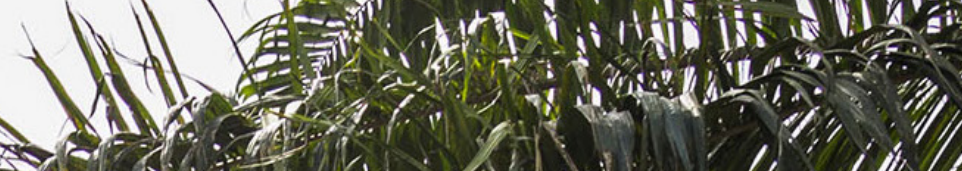




\section{What do we know about migration dynamics and patterns in sub-Saharan Africa?}

The general patterns of rural migration in sub-Saharan Africa are very specific when compared to other regions. Shaped by the socio-economic and political conditions of the continent (section 1.1) and a unique demographic context (3.1), they are characterized by three main features: (i) most of international African migration occurs within the continent; (ii) internal migration is the dominant form of migration; and (iii) renewed and diverse forms of migration such as rural-rural or circular migration develop besides the more traditional rural-urban pattern. Overall, migration in Africa has become a more complex and diverse process in terms of intensity of movements, as well as diversity and types of destination and trajectories (3.2). These contrasted and diverse migration patterns create new functional spaces that are shaped by socio-economic networks depending on the characteristics of changing rural-urban linkages and migrants' profiles, which are also more diverse (3.3). These new characteristics contribute in return to the reconfiguration of migration patterns in recursive loops of complex causality.

\subsection{A unique demographic context}

Rural out-migration in SSA is taking place in a unique context characterized by a continued growth of population at an unprecedented scale, a related massive expansion of a young labour force, as well as a steady growth of rural population due to a delayed and stabilized pace of urbanization (Losch, 2016b). These processes result in a challenging densification of rural areas, with direct impacts on natural resources and the nature of rural livelihoods, notably an increased mobility and the diversification of activities, which directly affects migration patterns.

Sub-Saharan Africa was the last region in the world to engage in its demographic transition and, unlike Asia, this transition is slower than expected. While in Southern Africa and some coastal West African countries the number of children per woman has dropped to less than three, most of other regions of the continent show slower and erratic declines (Guengant and May, 2013). As a consequence, demographic projections are regularly revised upwards by the United Nations. Between 2010 and 2017, the estimated SSA population in 2050 was increased by 208 million people, with the region projected to reach 2.2 billion inhabitants by the mid-century (UNDESA, 2010, 2017). This demographic growth represents a massive, unprecedented change in scale.

At the same time, SSA is also unique in the enduring importance of its rural population. In 2018, an estimated 60 percent of people were still living in rural areas (UNDESA, 2018) and the region remains mainly rural due to its relatively recent urbanization process (from the 1950s). ${ }^{19}$ The urban population has increased tenfold since the 1960s, mostly through a dual dynamic of densification from the bottom with burgeoning small towns, and metropolization to the top with booming megapolises - e.g. the South Nigeria megapolis from Onitscha and Ibadan to Lagos and spreading towards the neighbouring Benin (Chatel et al., 2016). However, urban growth has stabilized at around 3.5-4 percent per year today, against 5 percent and more before the 1980s - a result of the limited structural transformation of most of SSA economies and of the fiscal austerity related recession between 1980 and 2000 . While rural population has grown at a slower pace (estimated at 1.7 percent, with some countries still at 2.5 percent and more), a continuous densification of the rural space has taken place due to the growing size of the rural population.

As a result of the demographic growth, the labour force of the region has increased by 330 million between 1985 and 2015. In parallel, a change in the age structure, with a growing number of people entering the economically active group (aged 15 to 64 years) has progressively improved the effective

${ }^{19}$ Eight SSA countries only have less than 50 percent of rural population. 
dependency ratio ${ }^{20}$ from nearly 1 in the 1980 s to 1.2 today. However, by 2050 , the number of active people should increase by more than 800 million (2.5 times more than in the previous 35 years) and therefore the utmost challenge for SSA is to generate enough employment in order to absorb its booming labour force. The annual cohort of youth entering the working age group in 2015 was estimated at nearly 20 million of which around 60 to 65 percent were located in rural areas.

This dynamic puts a huge pressure on rural economies, particularly on agriculture through an increasing pressure on natural resources. SSA has long been under-populated but today the picture has changed: the density in 1950 was 8.2 inhabitants per $\mathrm{km}^{2}$ and it reached 44.3 in 2015 . These averages mask huge differences between regions and countries. Sparsely populated areas due to adverse natural conditions (e.g. Namibia) or historic under-population (e.g. the Congo Basin) coexist with dense settlements (e.g. the East African highlands, the Sudanian zone, and export-oriented agricultural areas). In dense settlement areas, this huge pressure on many local agrarian systems raises the question of their viability. Tensions between uses (agriculture versus urbanisation or mining) and users of land and water are growing rapidly, sometimes exacerbated by the consequences of climate change (Magrin and Losch, 2013; Chamberlin et al., 2014).

\subsection{Continuity and diversification of migration patterns}

This unique context is the place where a growing diversity of migration patterns have taken place and continue to develop. SSA's migration today is characterized by three major features: i) internal and international migration to African countries prevails over overseas migration, ii) rural-urban migration remains prominent - a consequence of the existing large rural population and the ongoing urbanization process, and iii) diverse rural-rural, urban-rural and circular migration have also developed, and are recognised as core and growing dynamics.

\subsubsection{Intra-African migration and its historical roots}

Migration has historically structured Africa which is often portrayed as a continent on the move (Bakewell and de Haas, 2007; Flahaux and de Haas, 2016). In 2015, about 33 million Africans were living outside their home countries, but more than half of these international migrants had moved within Africa (UNDESA, 2015a). Yet, this figure masks sharp differences between North Africans migrating overseas (90 percent) and sub-Saharan Africans mostly moving within Africa (nearly 70 percent), often to neighbouring countries. Western and Eastern Africa are the most dynamic regions in terms of sending and receiving countries. With respectively 5.7 and 3.6 million intra-regional migrants in 2015 - counting for 97 percent and 67 percent of total migrants - they exemplify SSA's strong intra-regional dynamics, with leading hosting countries like Côte d'Ivoire, Nigeria, Kenya and Ethiopia. They also highlight the role of regional economic communities, which adopted regulations facilitating the free movement of people (see below). South Africa is the other major hub for intra-African migration. According to the 2016 Community survey, the country counts 1.6 million born outside of South Africa, mostly from Central, Eastern and Southern Africa, but irregular migrants - who are a most debated issue in national politics could reach a maximum of almost the same number.

However, the effective movements of people are even stronger as international data neither include significant unrecorded intra-African migration, nor the dynamics of circular or non-residential migration between countries and within countries (Flahaux and de Haas, 2016; Adepojou, 2000a). These forms of migration, although less visible because poorly measured, are recognised as being core for the dynamics of current African migration (Potts, 2013; Black et al., 2006). Indeed, if African migration is partly facilitated by free circulation regimes within regional economic blocks, it is also resulting from the porous nature of national borders that facilitates circulation of people and informal cross-border trade (Nshimbi and Moyo, 2018). Moreover, evidence from several countries in different regional contexts suggests that

${ }^{20}$ Ratio between working age and non-working age people. 
internal migration is often the dominant migration pattern across SSA (cf. figure 2). It represents about 80 percent of migration in Nigeria and Uganda, 50 percent in Kenya and Senegal, but 38 percent only in Burkina Faso due to its specific historical relation with bordering Côte d'Ivoire. This supports global estimates that consider the number of internal migrants as six times higher than the number of emigrants (UNDP, 2009).

Figure 2 Rural and urban migration by destination (selected countries)

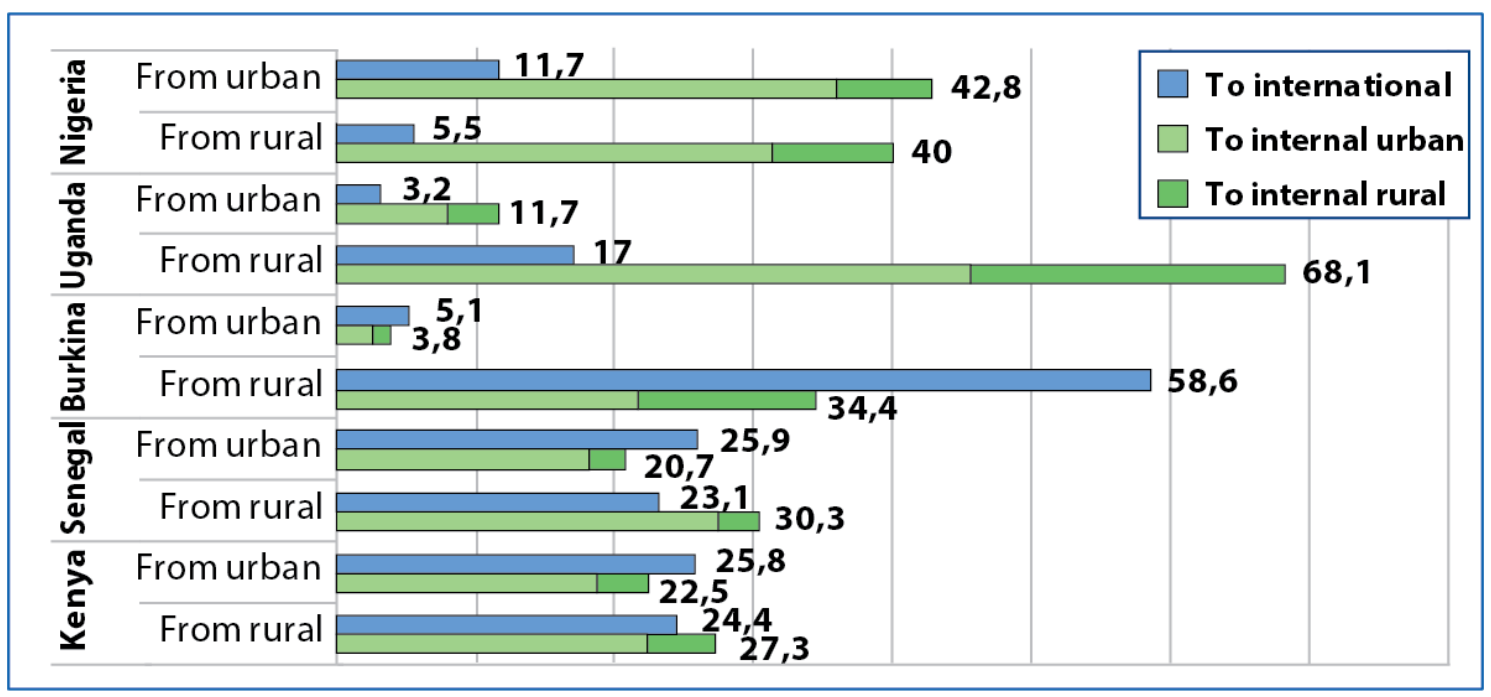

Source: Atlas FAO-Cirad, spread 2 - Mercandalli, S and Losch, B., eds., 2017.

The importance of circular migration within and between countries results from the consolidation and development over time of networks rooted in structured economic, social and family relations, which were progressively facilitated and strengthen by the improvements of infrastructure and communication.

\section{a. Early and colonial times}

Major migratory flows are constitutive of the history and the expansion of several ethnic groups, such as the Bantu from Central to Southern Africa. Long-standing and long-distance movements of people also occurred from north to south, supporting the development of the much debated 'Hamitic myth' in East Africa (de Bruijn et al., 2001), as well as across the Sudanian and Sahelian regions. These migration have resulted in multi-layered processes of settlement and contributed to the consolidation of the ethnic mosaic characterizing the specific dynamic of African population (Adepoju, 1995b).

Although some of these movements lack historical evidence, many authors agree that they have played and continue to play a significant role in the construction of Africa (Bilger and Kraler, 2005). These movements of people were initially associated with the search for safe land for farming or grazing in response to the variations of climate or socio-political circumstances (pilgrimages, internecine warfare,and slavery). Except when villages were abandoned (Nkamleu and Fox, 2006), migration was generally circular, of short duration and seasonal (Bakewell and de Haas, 2007, Chapman and Prothero, 1983). For instance, over centuries, pastoral nomads seasonally moved with their livestock in the search of green pastures: in the Horn of Africa, between today's Somalia and Ethiopia, in East Africa between Kenya and Tanzania (Makinwa-Adebusoye, 1983, 2006), in West Africa between northern Nigeria and Cameroon (Gwen, 1976) and between the Sahel and the Sudanian region. The trans-Saharan and transAtlantic trade, deeply structured by slavery, increased the circulation of very mobile groups organized around ethnic, religious and solidarity networks like Diola, Soninke, Hausa, and Pulaar (Charrière and Frésia, 2008). 
With the drawing of formal borders by and between European rulers in the aftermath of the Berlin Conference (1885), colonization impacted the movement of people and the prior territorial organization. Ethnic and cultural groups were divided between different colonies (Adepoju, 1995b) and the colonial project, based on the exploitation of local resources, led to a new spatial polarization impacting migration. Each colonial power developed its own infrastructure. It was generally spatially oriented, perpendicularly to the coast (with a toothcombs shape) where a port was built that was often both the main town and a railhead to ship out local commodities (Magrin, 2013; Losch, 2016a). It was the start of the current urban network and its development and of the expansion of agricultural exports and mining activities.

This new spatial framework was consolidated by the introduction and enforcement of colonial policies based on various coercive measures like forced labour, forced population displacements (Charrière and Frésia, 2008), and taxes which were motivated by colonial needs. It was also strengthened by new incentives related to the development of the cash economy (fostered by the obligation to pay taxes) with opportunities to access direct or indirect paid employment (waged labour in agriculture, mining, services and share-cropping systems in agriculture).

It resulted in new migration dynamics and the development of rural - urban patterns from the hinterland to coastal cities and of export agriculture and mining areas. Many of these migration were circular, often seasonal, like in Côte d'Ivoire and the Gold Coast (today Ghana), where they contributed to the development of the plantation economy based on coffee and cocoa, or in Senegal and Gambia where seasonal workers (named 'navetanes') were pillars of the expansion of groundnut production (Ndiaye and Robin, 2010).

Beyond colonial rivalries, cooperation between colonial powers for a profitable exploitation of local resources resulted in organized flows of workers from labour reserves regions. They were regulated by specific treaties, like between Portuguese Mozambique and South Africa (providing workers to South African mines), or between Spanish Guinea (today Equatorial Guinea) and British Nigeria (providing workers from the Calabar region to cocoa plantations in Fernando Póo island, today Bioko). Cooperation was also formalized between different territories under the same colonial rule. This was the case in British East Africa and in French West Africa, where Côte d'Ivoire and Haute Volta (today Burkina Faso) had a joined migrant labour office ${ }^{21}$ which formalized the migration of workers from North to South.

\section{b. Post-independence: between new barriers and tentative integration}

These long-standing migration patterns, blending precolonial and colonial dynamics, contributed to shape the spatial organization of the continent, with pre-emerging poles of urbanization which were mostly coastal cities - Dakar, Abidjan, Accra, Lomé, Cotonou, Lagos, Douala, Maputo, Dar-es-Salaam - and a few others inland ones like Ibadan, Leopoldville (today Kinshasa), Johannesburg and Nairobi.

Dual and contradictory processes were at play from the years of independence, which occurred mostly in the early 1960s. They resulted from the consolidation of the new nation states on the one side, and the emerging and fragile pan-Africanist movement towards increased integration on the other side.

Independence conditions accentuated the pre-existing spatial arrangement because each new state tried to build its national unity from what already existed, strengthening the administration, and expanding local equipment and services from the new capital city. Struggle for political power resulted in the dismantling of colonial federations (French Western and Equatorial Africa, British East Africa, Federation of Rhodesia and Nyasaland). As a result, new national borders were consolidated by the new political powers, which were in situation to control the rent system (Magrin, 2013) based on extraction of natural resources (agriculture, forestry and mining) and control of trade flows. ${ }^{22}$

\footnotetext{
${ }^{21}$ The Syndicat interprofessionnel d'acheminement de la main-d'œuvre (SIAMO) created in the early 1950s.

${ }^{22}$ Hence the historic feature of the "gatekeeper" (Cooper, 2002) because crossing national borders produces the rent based on exports and imports control and taxation, the port-capital becoming the system's nerve centre.
} 
With a few exceptions like Côte d'Ivoire, most of the new states introduced restrictions on residency, employment and circulation for foreign nationals, often as a result of local politics supporting 'national preference' for access to the labour market (Adepoju, 2000a) and therefore fuelling xenophobia. Times of political turmoil and economic recession (often closely connected) were more favourable to these dynamics like in Ghana in the 1970s, or the spectacular deportation of 1.3 million foreigners by Nigeria in two weeks in January 1983 (Afolayan, 1988). During that period, Ghana and Nigeria turned from net immigration to net emigration countries (Black and King, 2004).

However, other forces supporting integration have also been at play driven by the objectives of panAfricanism. Progresses at the continental level were quite slow, with the creation of the Organisation of African Unity (OAU) in 1963, followed by the African Union in 2001. The most tangible successes are found in the multiple processes of regional integration, which started progressively from the 1970s with the Economic Community of West African States (ECOWAS) created in 1975. There are today eight regional economic communities (RECs) ${ }^{23}$ and most intergovernmental protocols include free circulation, residence and settlement of people. Even if those protocols are sometimes poorly enforced - because often the right to reside and work remains controlled - regional integration strengthens migration flows toward the main hubs like South Africa in the SADC, and Côte d'Ivoire and Nigeria in the ECOWAS (Adepoju, 2000b).

Nevertheless, these dual and contradictory processes of withdrawal into the nation state and development of regional and African integration were simultaneously disrupted by other driving forces. The first one is related to the environment and particularly droughts. Major ruptures were the Sahel, with two crisis peaks in 1973-74 and 1982-84, and Ethiopia in the mid-1980s. Other regions were also particularly affected over the last three decades and continue to suffer from the deterioration of climatic conditions, primarily the Horn of Africa (Somalia, North-East Kenya), Sudan and South Sudan, Chad, and parts of Southern Africa. All these climate related events deeply affected rural communities of agro-pastoralists, with famine and herd losses, and fuelled migration.

Another source of disruption has been recurring conflicts, which affected the continent since the 1960s. They were motivated by liberation movements in Southern Africa with the delayed independence of Angola, Mozambique, Rhodesia (today Zimbabwe) and Namibia in the 1970s-1980s, intensified by the rivalries of the Cold War and the involvement of the apartheid regime of South Africa. They also resulted from the difficult consolidation of the new national states, due to insufficient skilled human resources and weak governance, austerity policies related to structural adjustment programmes leading to worsening socio-economic conditions, which sparked civil and regional wars. Among others it can be mentioned: in East and Central Africa, Somalia and Ethiopia, and the Great Lakes region; in West Africa, Liberia and Sierra Leone, and then the major crisis in Côte d'Ivoire, affecting the power engine of the region and that deeply impacted sub-regional migrations with hundreds of thousands of migrants returning at least temporarily to Burkina and Mali (Losch, 2005).

Today, the destabilization of the Sahel, in relation with jihadism fuelled by rural poverty and the disintegration of Libya, is a major new threat disrupting previous migration networks and leading to movement of refugees. These poles of instability contribute to the emergence of new migration routes to Europe, mostly via Libya and Morocco.

In all these contexts affected by conflicts or climate-related events, free movements of people and workers were and are substantially replaced - over very variable periods of time - by forced displacements (Oucho, 1995; Bakewell and de Haas, 2007). These displacements mostly engage rural-rural and rural-urban movements (Nkamleu and Fox, 2006) and contribute to the complexity of today's migration patterns and processes.

${ }^{23}$ In addition to ECOWAS: the East African Community (EAC), created in 1967 and reinitiated in 2000; the Economic Community of Central African States (ECCAS) in 1983; the South African Development Community (SADC), only created in 1992 but initiated in 1980; the Arab Maghreb Union (AMU) in 1989; the Common Market for Eastern and Southern Africa (COMESA) in 1994; the Intergovernmental Authority on Development (IGAD) in 1996; and the Community of Sahel-Saharan States (CEN-SAD) in 1998. Other regional groupings exist but they do not have the same status with regard to the African Union. 


\subsubsection{Revisiting rural-urban migration}

All these deeply rooted factors of change and recurring specific circumstances have shaped rural migration. What is old and what is new in the on-going processes? According to Ma Mung et al. (1998), migration all around the world is today impacted by globalization, which changes attitudes and practices. Three main consequences are identified: the transition from definitive return to alternative return; the development of diaspora and community networks; and an increased circulation of individuals. Africa has followed the same kind of dynamics from the point of view of migrant volumes and new migratory practices, somewhat exacerbated by the specific context of the continent. These new dynamics, still difficult to grasp, contribute to a progressive spatial reconfiguration and the emergence of new territories shaped by people's practices.

Rural migration in SSA today is characterized by the co-existence of traditional rural-urban and ruralrural movements of people (Nkameleu and Fox, 2006) and by new and renewed practices resulting in contrasted patterns.

Data displayed in figure 2 (above), representing a small sample of five West and East African countries, remind us that the majority of migrants originate from rural areas, particularly in Uganda ( 85 percent) and Burkina Faso (91 percent), which are representative of many SSA countries. It reflects SSA's still growing and dominant rural population and it is not a surprise that already significantly urbanised countries like Nigeria, Senegal and Kenya have more migrants coming from urban areas. Yet, even in Nigeria, rural migration is still a strong feature. Therefore, the traditional historical process of migration from rural to urban areas remains a strong pattern of SSA's migration, even if its rate declines over time: from 1.1 percent per year in the 1960 s, to 0.8 percent in the 1970 s, and 0.5 percent in the 1980 s according to Chen et al. (1998).

This trend explains why sub-Saharan Africa is the continent where the contribution of migration to urbanization has been the smallest (Berdegue et al., 2014b). This specific phenomenon is related to the conditions of SSA's structural transformation which have impacted its urbanization process, with a slower urban growth when compared to other parts of the world (Fox, 2012). Limited urban employment opportunities in the formal sector and the impact of structural adjustment programs (Suttie and Vargas Lindus, 2016), a large precarious informal sector, and the quasi-absence of safety nets have contributed to narrow the income gap between rural and urban areas. The importance of the rural-urban income gap has been the traditional driver for net rural-urban migration. However, in SSA, its reduction - which is supposed to temper migration flows - has not been the result of better-off rural population but of stagnating or reducing urban incomes.

Among the consequences of these intertwined processes was a rising livelihood vulnerability which has led to an increased propensity for mobility, not just into towns but also out of them (Potts, 2012). It also resulted into the development of circular migration that affected the net rate of migration to urban areas and contributes to explain the importance natural urban growth in SSA (Potts, 2013; Tshirley, 2015).

The vulnerability of urban livelihoods is not the only factor supporting circular migration. Broad ruralurban linkages in SSA are also embedded within strong social, cultural and political dimensions. Recently, in Senegal, Herrera and Sahn (2013) found that more than half of the total internal migration was temporary, and oriented from rural to rural or urban to urban, contrary to the widely studied processes of rural to urban permanent migration. Similarly, in countries like Zimbabwe or Mozambique, there is evidence of widespread national and international circular migration under a variety of forms (Potts, 2012; Mercandalli, 2017).

Rural-rural migration contributes to population redistribution in many countries. In various regions, it used to be the most common type of migration (Bilsborrow, 2002) and it continues to be a strong pattern 
related to the densification of the rural space, the progressive reduction of farm sizes, and the need to access to new land resources. In 2010, rural-rural flows constituted about one third of the internal movements of people in Burkina Faso and Uganda. Rural-rural migration are stimulated when land access is possible in other regions - like in Madagascar today - or when new activities develop, such as artisanal mining in several regions of West Africa. They often result from the possible extension of the agricultural frontier - a major feature of Côte d'Ivoire's development process - and can be associated with crises and changes in environmental factors. However, most often, rural-rural migration results from limited employment opportunities in cities. Rural migration to other regions within the country or in neighbouring countries is also often linked with dynamic cash-crop production areas (e.g. cotton, groundnut, cocoa, coffee and rice) that offer employment opportunities to a large number of workers, with sometimes migration routes initiated during the colonial times.

Migration in Africa has thus become a more diverse process as migrants' journeys are becoming increasingly multiple, complex and fragmented. Renewed and diversified migration patterns have thrived over the last decades between capital cities, small and regional towns, and their rural hinterlands (Mercandalli and Nshimbi, 2016). These dynamics witness the blurring of limits between rural and urban spaces and livelihoods, and the growing importance of rural-urban linkages (Tacoli, 2002), thus portraying a new African rurality (Pesche et al., 2016). The static rural and urban categories no longer capture the mixed lifestyles and socio-economic behaviours related to the intensifying rural-urban relations (AfDB et al. 2015; Losch, 2015).

\subsection{Rural migrants' profiles}

Migration patterns and dynamics in SSA are context-specific, crafted by more or less complex combinations of intertwined drivers: people migrate for different reasons, reflecting diverse situations, opportunities and constraints shaped by local circumstances. Poverty and wellbeing, economic diversification, political and social conditions at country and regional level also matter. Thus, migrants form a population that is diversified, reflecting the heterogeneity of local situations and selective processes. Their profiles are primarily determined by individual and local characteristics such as age, gender, household sizes, assets, activities, and incomes.

As such, rural migrants are not significantly different from other rural dwellers. This apparently paradoxical situation results from the relative homogeneity of SSA's rural areas - when compared with other regions of the world like Latin America - in terms of income levels and assets. When looking at rural households' income quintiles, rural poverty is widely spread with limited income differences between quintile 1 to 4 and a significant gap with the fifth quintile (Losch et al., 2012; IFAD, 2010). Instead of one core determinant, it confirms that, at the micro level, the decision to migrate results from a combination of specific individual and family characteristics (networks, education, and assets) shaped by the local context, and/or of individual preferences (cf. section 2 and figure 1).

Within the migration process itself, these individual and household features can, in turn, evolve and reshape migrants' profiles through feedback effects.

MRHS and LSMS data used in figure $3^{24}$ tell us that rural migrants are mostly young people, with limited education and employable skills, and that the majority of them come from households relying on agriculture. In 2015, Africa had the highest proportion of young international migrants (aged 15-24) representing 34 percent of total migrants, and the median age of all African international migrants was

\footnotetext{
${ }^{24}$ For the World Bank Migration and Remittances Households Surveys (MRHS): (1) Nigerian Migration Household Survey of 2009; (2) Ugandan Migration Household Survey of 2010; (3) Burkinabe Enquête ménage sur la migration et les transferts de fonds of 2010; (4) Senegalese Migration and Remittances Household Survey of 2009; (5) Kenyan Migration and Household Survey of 2009. For the World Bank Living Standard Measurement Study (LSMS): (1) Ethiopian Rural Socioeconomic Survey of 2013-14; (2) Malawian Integrated Household Panel Survey of 2013; (3) Nigerian General Household Survey of 2012-2013; (4) Ugandan National Panel Survey (UNPS) from 2009 to 2014; (5) Malian Enquête agricole de conjoncture intégrée aux conditions de vie des ménages (EAC-I 2014). See annex 1 for more details.
} 
29 (UNDESA, 2015b). Looking more closely at a diverse group of SSA countries (Senegal, Burkina Faso, Nigeria, Uganda and Kenya), these trends are similar for internal migration. Young people predominantly move within their home country and form the majority of rural migrants. Overall, around 60 percent of rural migrants are between 15 and 34 years old and female migrants are generally younger than their male counterparts. These general characteristics of youth profiles are confirmed by specific youth surveys and country case studies (Elder et al., 2015; Estruch et al. 2019).

The majority of international rural migrants are males - 60 percent to 80 percent in Eastern and Western Africa, respectively (UNDESA, 2015b) - which can partially be explained by specific social constraints affecting rural women (Chant, 1998). However, looking at internal rural migration, the situation is somehow more balanced. Further, in West Africa, some young girls aged below 15 years migrate whereas boys rarely do, indicating frequent employment as housemaids (cf. figure 3). The region is also characterized by larger families (with often seven or more members), which are usually more prone to have migrants, reflecting the difficulties of youth to access and inherit agricultural land, which is a potential incentive, among others, for migration (cf. section 4.1).

Figure 3 Characteristics of rural migrants and migrant households (selected countries)
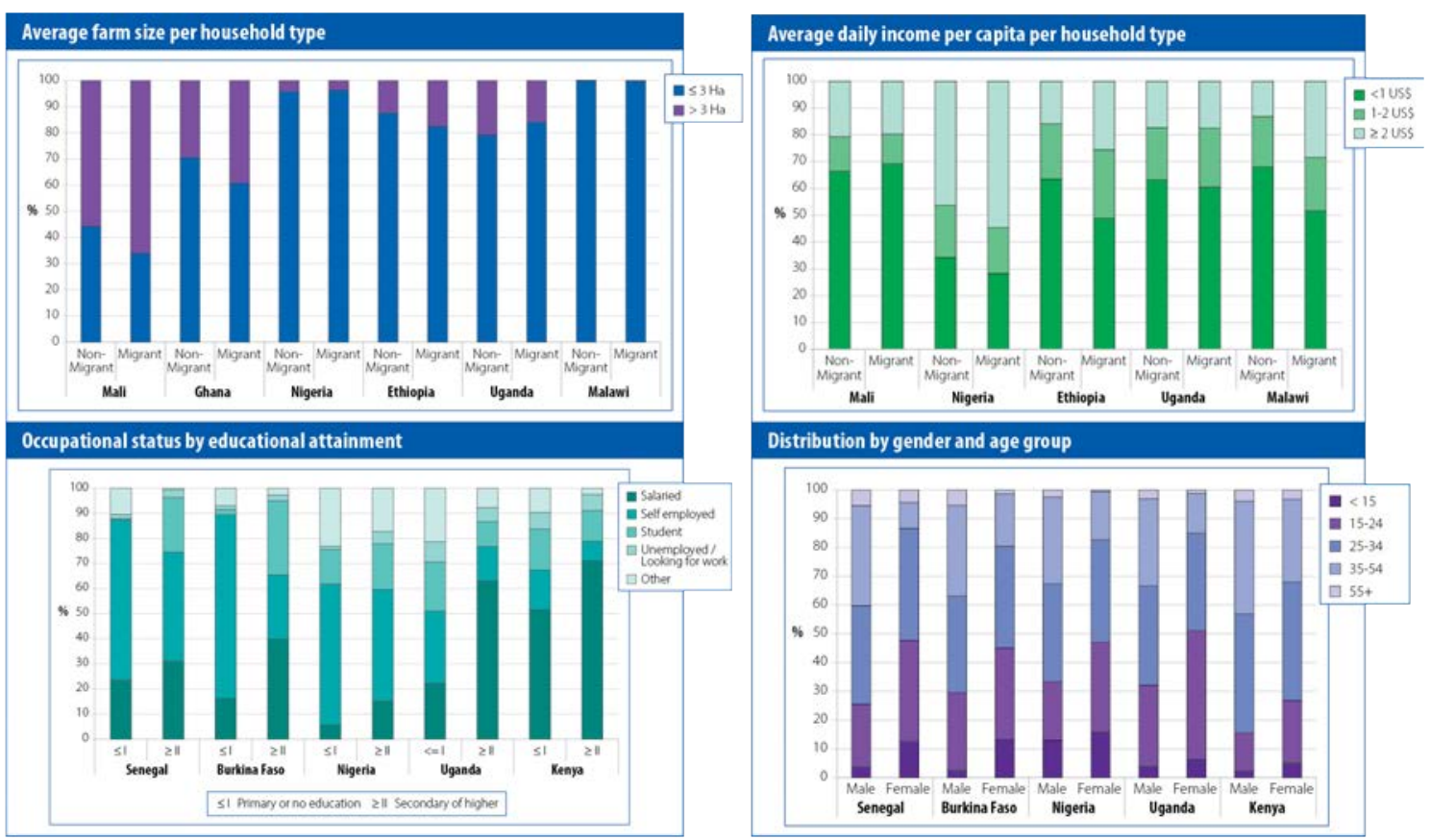

Source: Atlas FAO-Cirad, spread 3 - Dinbabo, Mensah and Belembeba (2017).

Rural migrants have lower school attainments than their urban counterparts. However, the majority of rural migrants come from households that have better educated members than non-migrant households (cf. Annex 7). This difference in terms of additional human capital can facilitate the first step of the migration process thanks to greater knowledge and social networks. When looking at the employment status of rural migrants at their destination (cf. fig. 3), it appears that the majority of those with limited or no formal education ends up in self-employed jobs, while those that have reached above the secondary education level are more likely to access waged employment.

On average, rural migrant households have slightly larger farm sizes (cf. fig.3), possibly indicating greater assets to support migration. At the same time, there is little difference between migrant and non-migrant households in terms of access to agricultural extension services or agricultural investments (notably irrigation systems, which are very limited). 
These results are confirmed by data robustness for a broad selection of socio-economic variables (cf. Annex 7).

Earnings of households with migrants are only slightly higher. Mali and Uganda display, on average, a quite under-differentiated situation. In Mali, the use of national level data masks the strong income effect of international migration in the few regions that have specialised in migration overseas. The share of migrant households earning more than US $\$ 2$ per day per capita is between 20 and 30 percent - about 5 to 10 percentage points more than the case of non-migrant households (cf. fig. 3). These few characteristics validate the long-held view that migrant households tend to be better off (Azam and Gubert, 2006; de Hann and Yakub, 2010) and that the poorest can rarely migrate as resources are needed to do so, in particular for international migration. The slightly greater wealth of households with migrants is also confirmed by their better access to infrastructure and services such as safe drinking water, sanitation and electricity. However, the differentiation between the two groups of households in terms of equipment (such as housing, radio or motorcycle) is limited (cf. Annex 7). 



\section{Analysing the drivers of rural migration: evidence from available data and case studies}

This section focuses on migration drivers. It first attempts to support or invalidate what is known about drivers and determinants of rural migration at the micro level, using available RuLIS datasets for six selected countries. Then, it further analyses selected situations from five additional country case studies. The case studies were selected based on their relevance with regard to the drivers at micro, meso and macro levels, and the existence of drivers complexes that are locally specific. It also illustrates the evolving configuration of drivers complexes overtime and addresses the specifics of the climate change as a driver of migration.

\subsection{What do we learn from existing datasets: drivers at individual and household levels}

By providing individual and household information, RuLIS data partly inform about the micro level drivers of migration (cf. fig 1). Descriptive and multivariate analyses confirm general knowledge about existing drivers. First, at the individual level, the main reason for migration is often an economic one although it is not the only one and does not prevail in all situations. Second, at the household level, data confirm that wealth is likely to be an important driver of rural migration as migrant households are among the better off, but household size and education attainments are also likely to be core drivers. Therefore, when considering households' potential drivers of migration, it appears that most may turn out to be determinants according to the country or the local context. It means there is no possible generalization: determinants of migration - defined as the drivers that influence the most the decision to migrate within a system of drivers (cf. section 2) - are context-specific. The overview of existing national surveys supports the importance of sub-regional analyses and the need to articulate micro level drivers with meso and macro levels ones in a complex of explanatory factors.

\subsubsection{Reasons for migration at individual level: age, sex and location matters}

At the individual level, the search for work or economic opportunities remains the dominant factor for rural migration for all countries (fig.4 and 5), followed by access to education, except for Ethiopia. The desire to join family generally ranks as the third reason for moving, reaching near and up to 30 percent in Ethiopia and Uganda (fig 5). It is worth stressing that even if economic reasons prevail in most countries, it is not the only driver and in the reality of individual lives it might often be combined with education (in particular for youth) and/or family motivations. Further, work motivated migration is usually higher in rural than urban areas reflecting the lack of opportunities and broad underemployment in the countryside. 
Figure 4: Main reason for migration (rural migrants, selected countries)

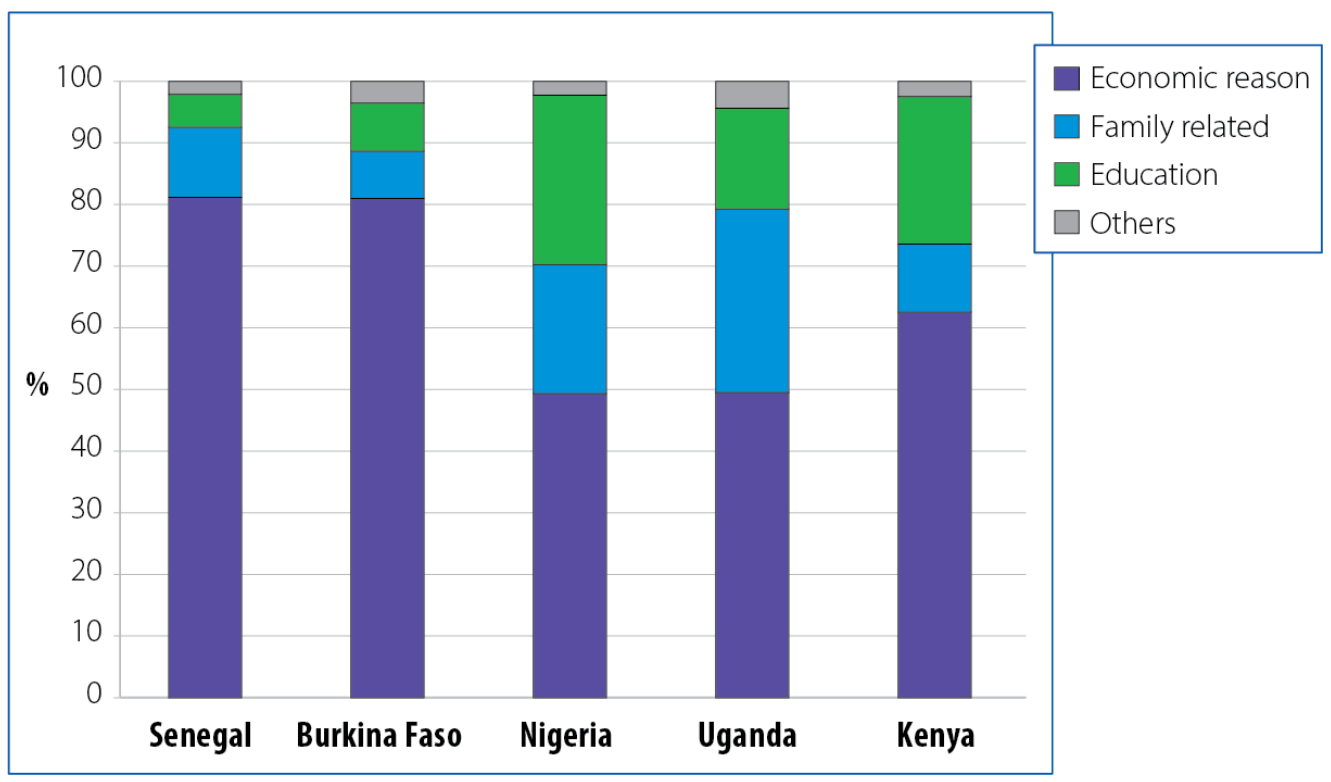

Source: Atlas FAO-Cirad, spread 3 - Mercandalli, S and Losch, B., eds., 2017

When looking at reasons for migration according to destination (cf. fig. 5), both at the national and rural levels, professional reasons are relatively more prominent for international migrants, with the exception of Kenya, and particularly for rural migrants.

Figure 5: Reasons for internal and international migration (selected countries)

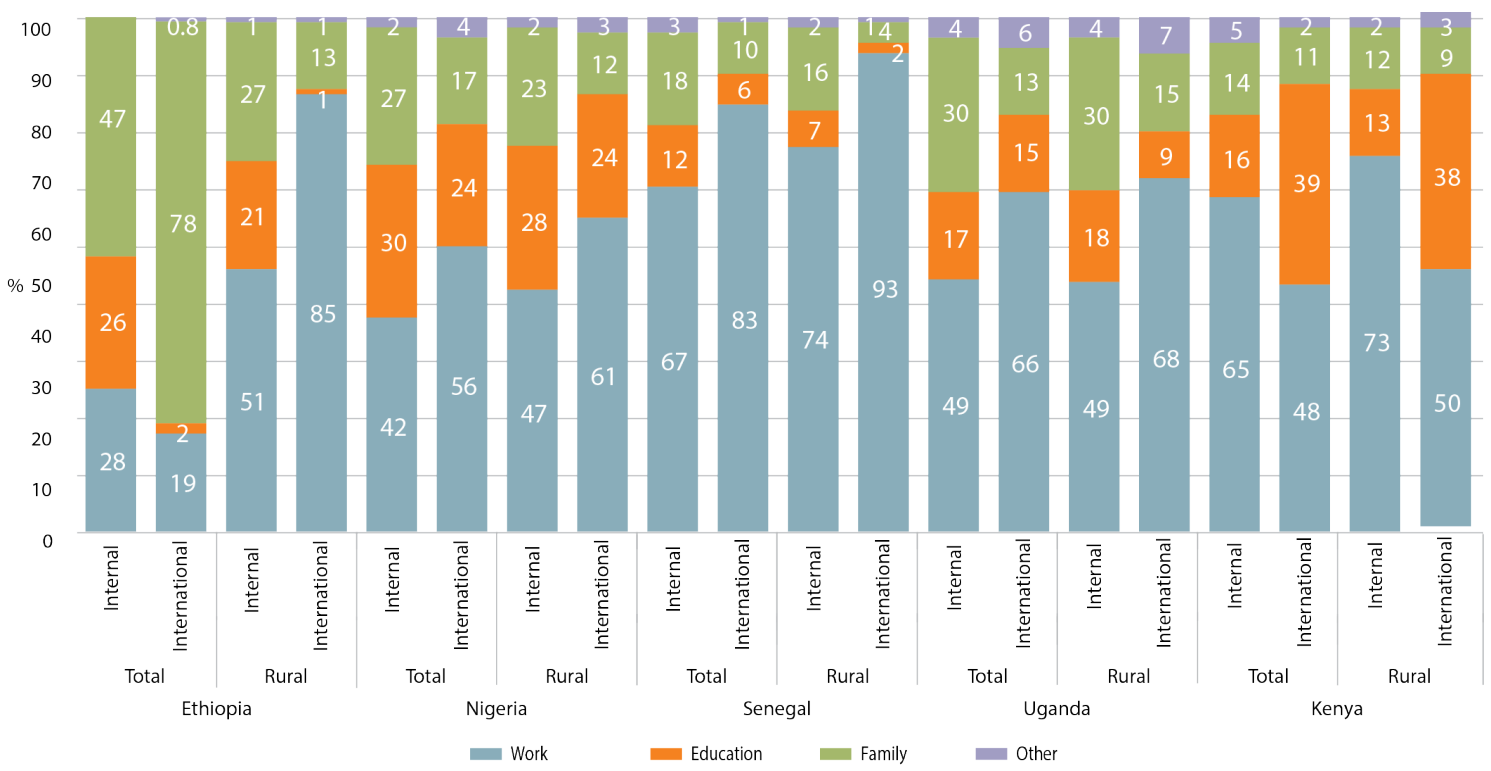

Source: FAO, 2017 
Finally, gender disaggregated data (cf. table 4) reveal that in most of the selected countries, women migrate primarily for family reasons, especially within their own country. After marriage, women are more likely to relocate to where their husband is living. In rural areas, the percentage of women migrating for work-related reasons is generally higher compared to urban areas. This is the same for the younger age group (15-34), except for Kenya.

Table 4: Reasons for internal and international migration by gender and age group (15-34)

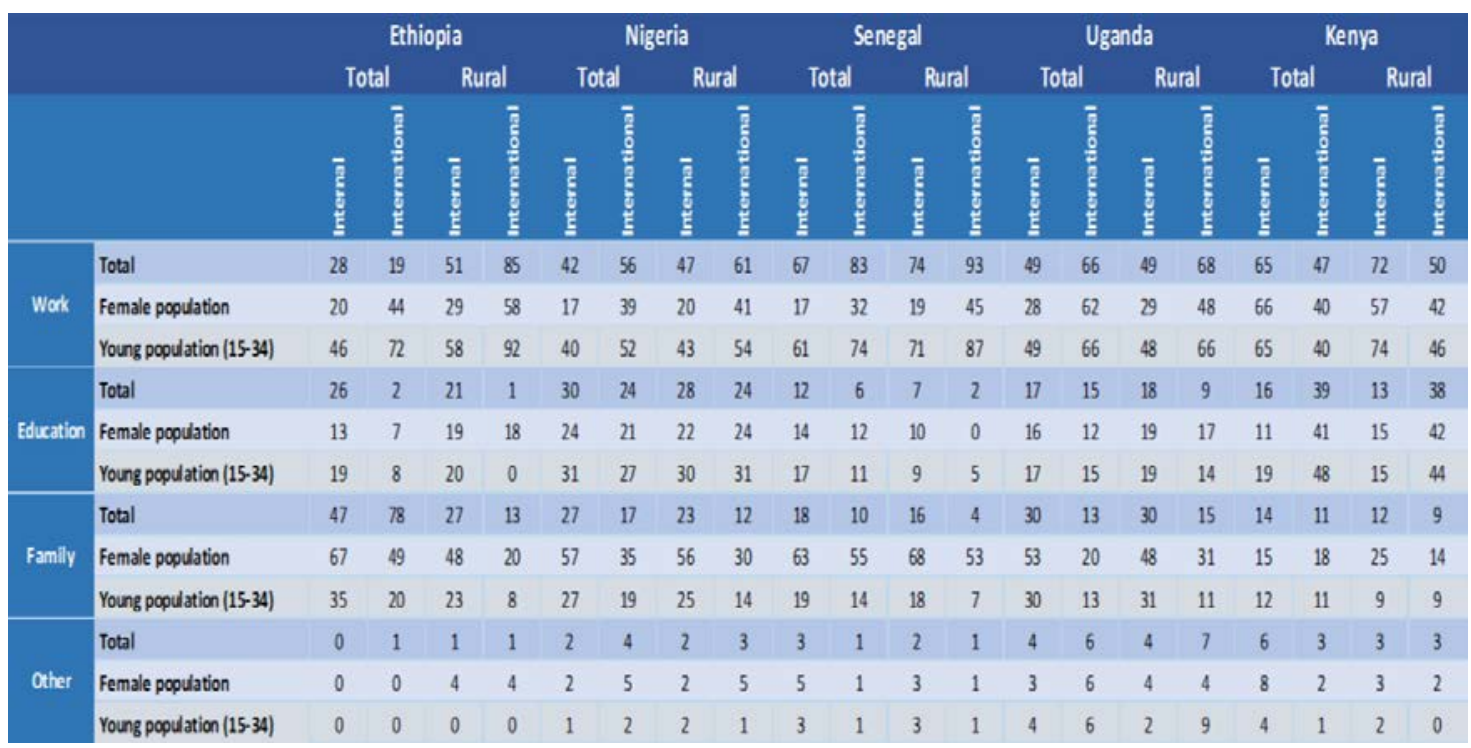

Source: FAO, 2017

The individual data from national surveys highlight and confirm the limits of analyses at the national level and the need to consider individual motivations by location, sex and age to understand the diverse dynamics that underpin individual migration decision. Deeper analyses at sub-regional level according to above categories would be even more informative.

\subsubsection{Reasons for migration at household level: both wealth and relative deprivation drive migration}

Drivers of migration also stem from the household level as family members can collectively make migration decisions together with the prospective migrant. This view, aligned with the New Economics of Labour Migration framework (Stark, 1991; see section 2), broadens the scope for understanding the drivers of migration. This is particularly relevant in rural areas and for family farming where strategic decisions for the allocation of family resources are often collectively made.

Cognizant of the hypothesis that household wealth is an important driver of rural out-migration in Africa (Awumbila et al., 2015; Azam and Gubert, 2006), a principal components analysis (PCA) was carried out to assess a relative household wealth indicator (cf. 1.3), which helped to comparatively understand how rural $\mathrm{MHH}$ and $\mathrm{NMHH}$ differed.

Results (factor scores) pointed housing conditions ("household has solid roof"), access to infrastructure facilities (electricity) and household ownership of tangible assets (cell phone) as variables capturing most of the variability of wealth and likely to be its main determinant, for both rural MHHs and NMHHs for each country (cf. annex 8). 
Further, based on this relative household wealth index, a quintile wealth indicator was generated for each country by clustering the index into poorest, second, middle, fourth and richest groups (Vyas and Kumaranayake, 2006; Córdova, 2009).

Overall, results reveal a trend: in four out of six countries, the proportion of rural MHHs belonging to the fourth and richest wealth quintile were higher compared to their rural NMHHs counterparts -24 , 37, 28 and 39 percent of $\mathrm{MHH}$ in the richest quintile. Further, for these same countries, the proportion of rural $\mathrm{MHH}$ who belonged to the first two quintiles (poorest and second) compared to rural $\mathrm{NMHHs}$ were lower. However, data from Mali and Ghana show different results: slightly different in Mali where the share of $\mathrm{MHH}$ in the second quintile is higher; a reverse pattern in Ghana where rural $\mathrm{MHH}$ are more in the poorest quintile and less in the richest (cf. fig 6). The results for Ghana can be explained by the relative importance of rural incomes related to cocoa cultivation - a quite profitable export cash crop - where rural migrants are more likely to be rural people with no or limited access to farm land. ${ }^{25}$

Nevertheless, these results based on non-causal, comparative analyses tend to validate the common assertion that most rural migrant households tend to be wealthier - as a result of positive returns to migration - and consequently can potentially afford to send out a family member within or outside of the country. But the divergent paths of Mali and Ghana also show that a relative deprivation can also motivate migration.

This finding corroborates detailed analyses on various waves of LSMS by Kafle et al. (2018) arguing that relative deprivation of wealth ${ }^{26}$ is positively associated with migration and that migration increases with the absolute level of wealth. This suggests that both absolute and relative deprivation need to be considered at the same time to better understand the drivers of migration: households make a migration decision by considering both their relative deprivation as well as their absolute levels of income or wealth (Czaika and de Haas, 2011; Quinn, 2006). Migration increases with wealth but it increases more among relatively deprived households. In addition, Kalfe et al. also state that the positive effect of relative deprivation on migration ("migration-relative deprivation relationship") is amplified in rural, agricultural and maleheaded households. This implies that policies that aim to reduce inequalities and support safe, orderly and regular migration flows may need to pay attention to the socioeconomic structure of the population for better results. Policies that account for the demographic and occupational heterogeneity and create opportunities for youth, rural residents, and farmers in their locality may do far better than those that target the general population (Kafle et al., 2018).

\footnotetext{
${ }^{25}$ A similar explanation can be proposed for Mali in relation to access to cotton production, another export cash crop.

${ }^{26}$ Household's relative deprivation depends on well-being status of other households in the community as well as the feeling of household's members about their position within the local wealth distribution. It is in this way that people from relatively more deprived households have higher incentive to migrate as migration occurs not only to maximize the expected income, but also to minimize the feeling of deprivation relative to their neighbours or communities (Stark and Yitzhaki, 1988; Stark, 1984; Stark and Taylor, 1991).
} 
Figure 6: Wealth quintiles by rural households' migration status -6 countries
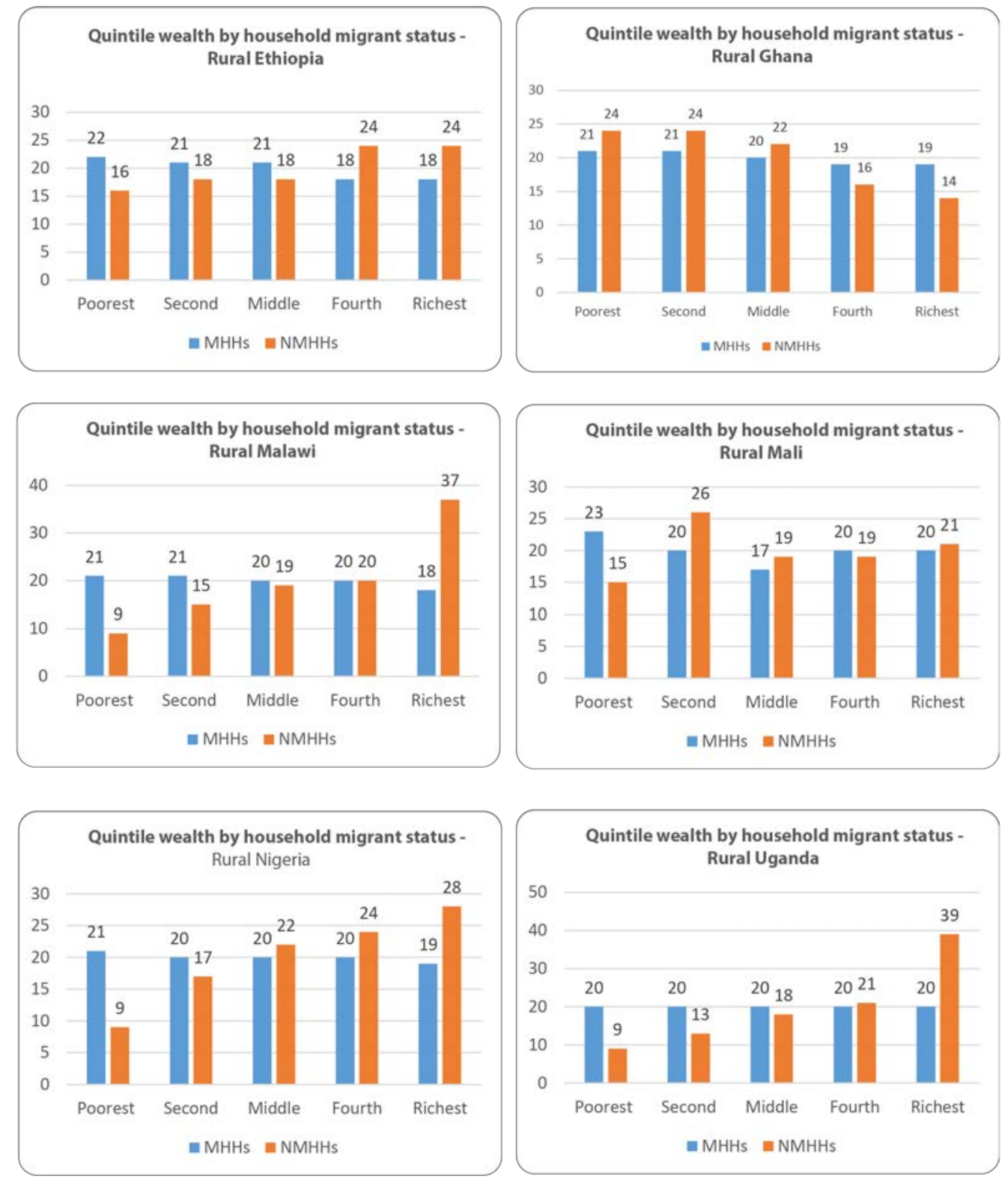

Source: computation based on RuLIS data

Using binary logistic regression (BLR) with eleven explanatory variables commonly used in the literature (see their definition in Annex 3), Table 5 presents the odds ratios that allow direct interpretation of determinants and drivers of migration. ${ }^{27}$

Results highlight that most of the selected variables contribute as determinants with significant differences between countries. It confirms the impossible generalization about determinants of migration and the fact that drivers with the most leading role within a system of drivers are context specific.

BLR yielded mixed results per country with the exception of household's size, which significantly predicted rural out-migration for most countries. Owing a cell phone was also found to significantly increase the likelihood of migration from rural areas. In most countries having access to ICTs facilitates the free flow of information between prospective rural migrants and their social networks and, consequently, contributes to the decision to migrate.

${ }^{27}$ An odds ratio is a measure of the association between two variables (the exponential of the coefficient), here between the possibly explanatory variable and being a migrant household $(\mathrm{MHH})$. When the odds ratio is greater than 1 , it means that the variable increases the likelihood of migration. Conversely, if the ratio is less than 1 , the variable is negatively associated. 
Contrary to assertions that rural households' experience of weather adverse conditions and market shocks tend to influence their propensity to send-out a household member, results show that neither experience of weather shocks nor market shocks are significant predictors for four countries (Malawi, Mali, Nigeria and Uganda). Overall, the mix of either push or pull human, demographic and economic factors of rural out-migration varies with the country according to origin and destination contexts. These factors highlight the existence of a blend of drivers and determinants of rural migration.

Looking at individual country ratios, a few trends can be further discussed with regard to the existing literature - results being interpreted all things being equal (ceteris paribus). In the case of Ethiopia, for the variables number of highest years of education in household and size of land owned, one additional unit is associated with an increase in the probability of out-migration of 5 and 14 percent respectively. This pattern is also found when the household has a working cell phone and a solid roof (increasing the likelihood of migration by 59 and 44 percent respectively). When women's share of household labour increases by 10 percent, the probability of migration increases by 6.9 percent. Conversely, having an additional person in the household and experiencing market shocks significantly reduces the probability of migration by 13 and 33 percent respectively. This result contrasts with the hypothesis that the size of the family and more importantly household's experience of shocks drive them to send out a member. In their study on Ethiopia, Tegegne and Penker (2016) found household's size to be a significant predictor of rural out-migration. This difference in results may be explained by the local context, and more likely by the fact that a single year was used here for the regression analysis with inherent endogeneity issues.

In Mali, highest years of education in the household and household's size were found to increase the likelihood of migration by 11 and 7 percent. Interestingly, in a household owning an operating cell phone, the likelihood of rural out-migration increases by a factor of 3.6 - the highest amongst the three significant predictors. 
Table 5: Logistic regression analysis results of determinants and drivers of rural out-migration

\begin{tabular}{|c|c|c|c|c|c|c|}
\hline \multirow[t]{2}{*}{ Variable } & \multicolumn{6}{|c|}{ Odds ratio results } \\
\hline & Ethiopia & Ghana & Malawi & Mali & Nigeria & Uganda \\
\hline $\begin{array}{l}\text { Highest years } \\
\text { of education in } \\
\text { household }\end{array}$ & $1.05^{\star *}$ & $1.23^{* *}$ & $1.13^{\star *}$ & $1.11^{\star}$ & 1.02 & 0.99 \\
\hline $\begin{array}{l}\text { Female share of } \\
\text { household labour }\end{array}$ & $1.96^{* *}$ & 1.64 & 1.49 & 0.29 & 1.61 & 0.60 \\
\hline Household size & $0.87^{* *}$ & $1.14^{* *}$ & $0.92^{*}$ & $1.07^{* *}$ & $1.07^{* *}$ & $1.19^{* *}$ \\
\hline Weather shock & 0.85 & n.a. & 0.93 & 1.33 & 1.15 & 1.19 \\
\hline Market shock & $0.63^{* *}$ & n.a. & 0.80 & 1.01 & 0.54 & 1.39 \\
\hline Size of land owned & $1.14^{* *}$ & 1.02 & $0.49 * *$ & 1.01 & $0.72^{*}$ & $0.64^{*}$ \\
\hline $\begin{array}{l}\text { Total livestock } \\
\text { owned }\end{array}$ & 1.03 & $1.01^{*}$ & $0.73^{*}$ & 0.96 & 0.79 & $1.11^{*}$ \\
\hline $\begin{array}{l}\text { Household owns } \\
\text { operating cell } \\
\text { phone }\end{array}$ & $1.59^{* *}$ & $2.06^{*}$ & $1.83^{* *}$ & $3.60^{* *}$ & $2.09^{* *}$ & 1.01 \\
\hline Solid roof & $1.44^{* *}$ & 0.93 & 0.96 & 0.79 & n.a. & 1.76 \\
\hline $\begin{array}{l}\text { Access to social } \\
\text { insurance }\end{array}$ & 0.89 & 1.16 & 0.71 & 1.55 & $0.19^{* *}$ & n.a. \\
\hline Access to electricity & 1.15 & 0.90 & 1.41 & $0.05^{\star *}$ & 0.95 & 0.83 \\
\hline Constant & $0.34^{\star *}$ & $0.00^{* *}$ & $0.05^{\star *}$ & $0.01^{* *}$ & $0.04^{\star *}$ & $0.01^{* *}$ \\
\hline $\mathrm{N}$ & 2,916 & 4,943 & 2,954 & 1,946 & 2,609 & 2,296 \\
\hline Wald chi2 & 93.87 & 163.49 & 103.65 & 84.78 & 50.89 & 34.53 \\
\hline P-vale & 0.0000 & 0.0000 & 0.0000 & 0.0000 & 0.0000 & 0.0002 \\
\hline Pseudo R2 & 0.0540 & 0.0951 & 0.0878 & 0.0922 & 0.0535 & 0.0578 \\
\hline
\end{tabular}

Source computations based on RuLIS data.

Note: ${ }^{* *}$ Significant at the 1 percent level. *Significant at the 5 percent level; n.a. Not available.

The limited results yield from the exploration of available data are a strong reminder about the difficulty in investigating the drivers and determinants of rural migration (see section 1 ). ${ }^{28}$ Existing datasets only allow to inform about broad drivers of rural out migration, focusing on the micro level (individual or household) and on a limited number of dimensions. They are more suitable to analyse rural migrants and households' profiles than the drivers of migration per se, even if they also provide a wealth of information on rural migration dynamics in the surveyed countries. This assessment calls for a broader qualitative approach, bringing into the picture other analytical levels (meso and macro) and other dimensions of existing drivers for a better understanding of their specific local nature.

${ }^{28}$ The low levels of pseudo-R2 with regard to the size of the samples corroborates this finding. 


\subsection{Bringing other dimensions and levels of drivers of rural migration}

Through a selection of five case studies (see Mercandalli and Losch, 2017) - namely Senegal, Madagascar, Zambia, South Africa and Mozambique - this section sheds light on core dimensions of the proposed framework, intending to highlight stylized facts about existing drivers complexes, including their variety, commonalities and specificities, and how they shape the diverse form and structure of migration patterns at national and regional level, according to the context in which migration processes take place (4.2.1).

In addition, two situations are analysed which are significant for the understanding of the nature of drivers complexes. First, the case of south Mozambique evidences the shifting nature of drivers complexes over time, unfolding migration processes rooted in colonial labour systems and ongoing liberalisation. Second, the complex nature of climate change as a driver of rural migration is addressed and its contribution to drivers complexes in a wide range of African migration patterns is highlighted (4.2.3).

\subsubsection{Drivers and patterns of rural migration: main insights from five country case studies}

Common features of the drivers of rural migration can be identified in the different case studies (cf. table 6). First, echoing the ongoing demo-economic transition in SSA, a common driver at the micro level is the predominance of migrants in the active age (15-64 years), most of them being young active people moving for real or perceived opportunities of income generating activities. This is associated with migrants' basic level of education in most case studies - another micro level factor sustaining the migration process through evolving mindset and aspirations. Second, at macro or meso (regional) levels and linked to the above, all case studies reveal a relative demographic density in rural areas. Third, supporting previous research findings on the drivers of rural migration, environmental factors always play a role through the availability or access to resources as land, water, or the vulnerability of these factors. It is directly related to a significant pressure on natural resources resulting from the population patterns pointed before. However, they show different degrees of importance. Finally, improved infrastructure and communication are common features of contemporary drivers of rural migration, influencing their characteristics and fostering mobility towards more diverse destinations. Together, these initial considerations support the evidence that if economic drivers and particularly access to new income is important, it is always combined with a variety of non-economic drivers conditioning the migration process.

Beyond these commonalities, all case studies inform about the context-related specificity of drivers of rural migration, suggesting their unique combination and the greater role played by some drivers at particular geographical levels. For instance, in Madagascar, in addition to the common drivers reminded above, it seems that adverse climatic conditions and, above all, land pressure act as determinants of migration in many regions. It gives a crucial role to environmental factors in the migration processes but other specific drivers like religion or political instability are also embedded in the local drivers complexes. In Zambia and Mozambique, in relation with past colonial history, social and family networks are likely acting as determinants of migration patterns at the meso level, in interaction with specific regional drivers, like migration policy in Mozambique or new economic sectors in Zambia.

Another element is the diversity of migration patterns shaped by specific drivers complexes within the national space. Indeed, drivers complexes of rural migration have a particular relation with rural change and structural transformation, which calls for a multi-level approach dealing with the idiosyncratic dimensions of places of origin and destination.

In contexts facing major structural challenges, as illustrated by the deep spatial imbalances existing in Senegal, the drivers complexes of rural-urban migration are likely to accentuate the processes at play 
(Ba et al., 2018): the effects of migration on the socio-economic structures of areas of origin (through local investment in agriculture or others sectors) will take time to impact territorial development. On the contrary, in Zambia, internal rural-urban migration related to thriving medium scale farming and mining sectors might have deeper and quicker effects on rural change.

Table 6: Current patterns and drivers of rural migration: synthesis from 5 country case studies

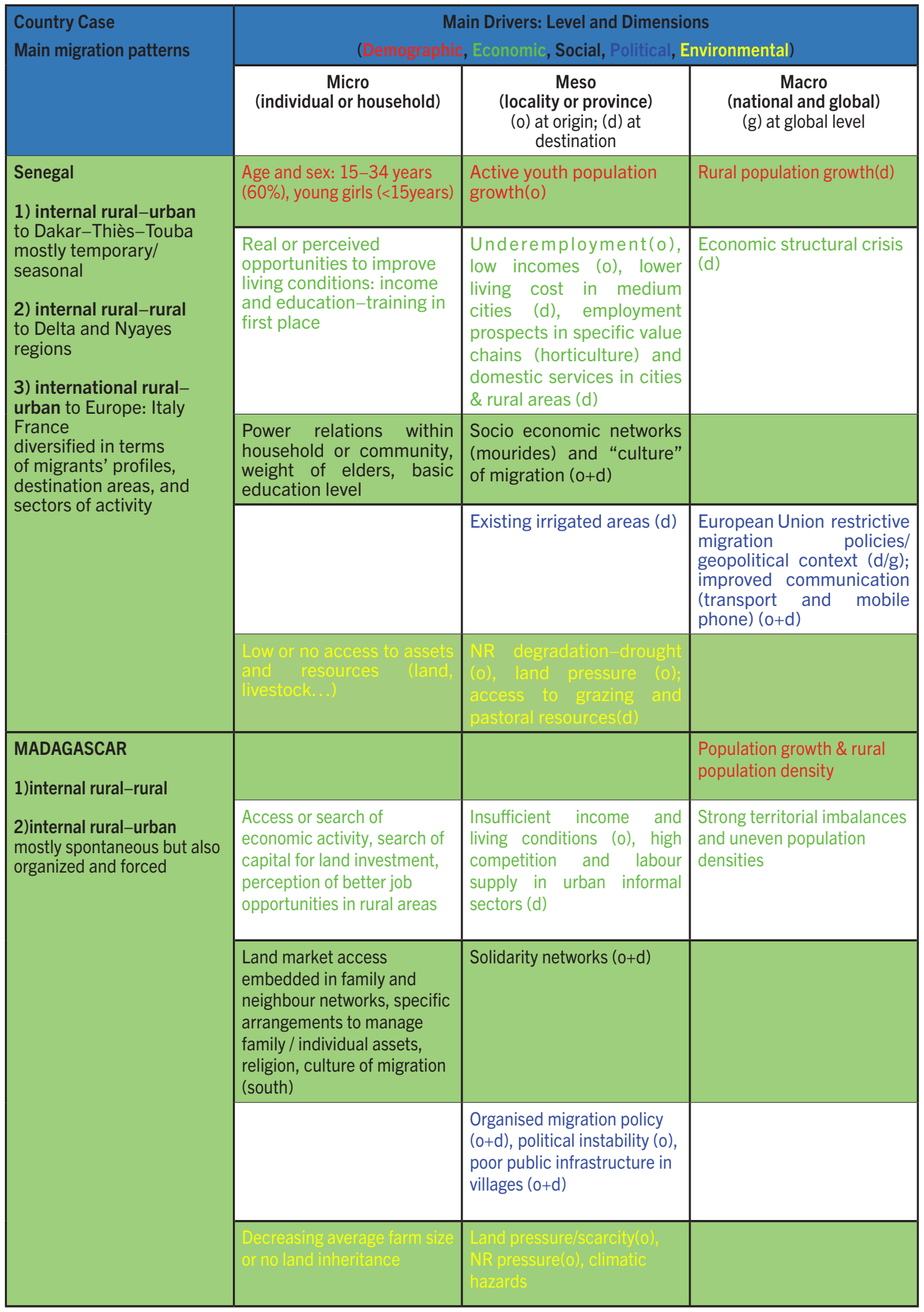




\begin{tabular}{|c|c|c|c|}
\hline \multirow[t]{2}{*}{$\begin{array}{l}\text { Country Case } \\
\text { Main migration patterns }\end{array}$} & \multicolumn{3}{|c|}{$\begin{array}{l}\text { Main Drivers: Level and Dimensions } \\
\text { (Demographic, Economic, Social, Political, Environmental) }\end{array}$} \\
\hline & $\begin{array}{c}\text { Micro } \\
\text { (individual or household) }\end{array}$ & $\begin{array}{c}\text { Meso } \\
\text { (locality or province) } \\
\text { (o) at origin; (d) at } \\
\text { destination }\end{array}$ & $\begin{array}{l}\text { Macro } \\
\text { (national and global) } \\
\text { (g) at global level }\end{array}$ \\
\hline \multirow{5}{*}{$\begin{array}{l}\text { ZAMBIA } \\
\text { 1) internal rural-urban } \\
\text { North and Western provinces } \\
\text { 2) internal urban-rural } \\
\text { 3) internal rural-rural } \\
\text { Western and Southern } \\
\text { provinces to the Central and } \\
\text { North-Western provinces } \\
\text { mostly diversified circular or } \\
\text { return migration }\end{array}$} & Youth & & \\
\hline & $\begin{array}{l}\text { Lukewarm perception } \\
\text { of urban opportunities, } \\
\text { search for additional } \\
\text { incomes, flexibility to look } \\
\text { for quick options }\end{array}$ & $\begin{array}{l}\text { New mining boom in } 2000 \\
\text { (d), } \\
\text { development of medium } \\
\text { scale farming (d) }\end{array}$ & \\
\hline & $\begin{array}{l}\text { Migration culture for male } \\
\text { (colonial mining), non- } \\
\text { economic motivations } \\
\text { (family), access to } \\
\text { education and to services }\end{array}$ & $\begin{array}{l}\text { Strong social network } \\
\text { inherited from past mining } \\
\text { labour dynamics }(0+d)\end{array}$ & $\begin{array}{l}\text { Better infrastructure \& } \\
\text { communication networks } \\
(0+d)\end{array}$ \\
\hline & & $\begin{array}{l}\text { Support to urban services \& } \\
\text { infrastructures (d) }\end{array}$ & $\begin{array}{l}\text { Better infrastructure \& } \\
\text { comm. networks }(0+d)\end{array}$ \\
\hline & & $\begin{array}{l}\text { Successive droughts and } \\
\text { animal diseases (o), high } \\
\text { land availability (d), good } \\
\text { rains (northern regions) } \\
\text { (d), or adverse climatic } \\
\text { conditions, land scarcity } \\
\text { which put pressure on } \\
\text { agricultural activities(o) }\end{array}$ & \\
\hline \multirow{4}{*}{$\begin{array}{l}\text { SOUTH AFRICA } \\
\text { 1) internal rural-urban } \\
\text { both circular and permanent } \\
\text { towards rural towns or cities } \\
\text { within the same province or to } \\
\text { another province. }\end{array}$} & $\begin{array}{l}\text { Active age } 15-64 \text { years and } \\
\text { mostly youth, household } \\
\text { head, tranditionally mostly } \\
\text { men but increseangly also } \\
\text { women }\end{array}$ & & \\
\hline & & $\begin{array}{l}\text { Unemployment }(0) ; \quad \text { low } \\
\text { returns in smallholder } \\
\text { agriculture(0) }\end{array}$ & $\begin{array}{l}\text { Persistent rural urban gap } \\
(0+d)\end{array}$ \\
\hline & $\begin{array}{l}\text { Secondary education, } \\
\text { family-related reasons, } \\
\text { aspiration to better living } \\
\text { condition/livelihoods in } \\
\text { urban areas }\end{array}$ & & \\
\hline & & $\begin{array}{l}\text { Under equipment (water, } \\
\text { electricity) \& services } \\
\text { (health, education) in rural } \\
\text { communities (o), social } \\
\text { housing, education in urban } \\
\text { centres (d) }\end{array}$ & $\begin{array}{l}\text { Improved infrastructure } \\
(0+d)\end{array}$ \\
\hline \multirow{5}{*}{$\begin{array}{l}\text { MOZAMBIQUE } \\
\text { 1) international rural urban } \\
\text { 2) internal rural urban } \\
\text { diversified both circular and } \\
\text { permanent }\end{array}$} & $\begin{array}{l}\text { Mostly men, active age } \\
15-64 \text { years }\end{array}$ & & \\
\hline & $\begin{array}{l}\text { Aspiration or access to new } \\
\text { income / activity }\end{array}$ & Low return agriculture (o) & $\begin{array}{l}\text { SA primary sector } \\
\text { restructuring \& job loss (d); } \\
\text { growth with inequalities, rural } \\
\text { poverty (o) }\end{array}$ \\
\hline & $\begin{array}{l}\text { Culture of migration since } \\
\text { colonial time and loss of } \\
\text { interest in farming, family } \\
\text { reason and access to } \\
\text { education }\end{array}$ & $\begin{array}{l}\text { Consolidated strong social } \\
\text { networks between previous } \\
\text { war refugees/IDP and } \\
\text { relatives in Mozambique } \\
\text { rural areas }(0+d)\end{array}$ & \\
\hline & & $\begin{array}{l}\text { Lack of services and market } \\
\text { access }(0)\end{array}$ & $\begin{array}{l}\text { South Africa laws discourage } \\
\text { permanent immigration }(d) ; \\
\text { improved infrastructures \& } \\
\text { comm }(0+d)\end{array}$ \\
\hline & & $\begin{array}{l}\text { Pressure on NR (land } \\
\text { degradation, drought) (o) }\end{array}$ & \\
\hline
\end{tabular}




\subsubsection{The evolution in time of drivers complexes: the case of Mozambique}

The history of migration between rural South Mozambique and South Africa, from colonial times to independence and post-apartheid, shows how the configuration of drivers of therural migration and related patterns deeply evolve over time. Shifting drivers complexes are rooted in the regional political economy and a range of environmental, sociocultural and economic factors acting locally in sending and receiving areas at both micro and meso levels. They result in a strong and sometimes very quick adaptation capacity of rural migrants and their families. In the last 15 years, renewed migration drivers complexes and patterns have resulted in a growing differentiation of rural livelihoods and in slow rural transformation.

During colonial time, circular migration have developed under the regime of the labour system related to the mining industry (Mercandalli and Anseeuw, 2017). The huge labour needs of the thriving South African mining sector led to bilateral agreement signed in 1897 between the Portuguese colonial power and the Transvaal government for the provision of workers. The cooperation system was improved in 1928 with a convention ensuring the provision of Mozambican migrant labour in exchange for taxes and incomes for the workers, whose return to their place of origin was enforced after each contract (GoM, 1928). This policy, targeting rural men, established South Mozambique as a 'labour reserve' (Amin, 1972). In the 1940-1950s, about one third of active males in Inhambane Province worked in South African mines, and to a lesser extent, on sugar plantations (First et al., 2001). With wages up to 300 percent higher than those offered by local Portuguese companies and planters under the forced labour system (xibalu), workers' choice was obvious: for a majority, it was the only way to escape both xibalu and an exploitive hut tax (Brock, 1989).

Regular short-term circular migration between the main gold and coal mining areas (mostly in Transvaal state) and rural localities of South Mozambique was the dominant migration pattern. In places such as Leonzoane (Massinga District), it concerned 65 percent of active men. A minor pattern was the migration under the xibalu system towards Mozambican cities and harbours (Maputo, Beira, Chimoio) for handling and railways construction, or agricultural labour (cotton, sugar).

With men spending more than half of their working lifetime in South Africa, this migration system translated into a deep restructuring of family labour and farm activities. It gave rise to dominant 'peasantminer' livelihoods in which men were engaged in low-wage labour, and women and children maintained a subsistence farming system at home.

A second period starts with the independence of Mozambique in 1975 that radically changed power relations between the new Marxist-oriented government and the apartheid regime (Abrahamson and Nilsson, 1995). Economic and military destabilization by neighbouring South Africa (and Rhodesia today Zimbabwe) directly and quickly affected prior migration patterns conditioned by warfare, drought, food insecurity and social networks at the core of the drivers complex of troubled independence times. First, South Africa cut labour migration enrolment to the mines: from 1975 to 1976, the recruitment of miners in South Mozambique dropped by about two-thirds (First et al., 2001). Second, in the early 1980 s, new economic and military actions contributed to undermining the socialist project that relied on state-owned farms producing for export and domestic food needs. Foreign-backed attacks led to the destruction of main national infrastructure, as well as disruption of economic flows. Moreover, the development of the Mozambican National Resistance (RENAMO) resulted in guerrilla activities that affected rural areas and prevented any regular agricultural production. When destabilization reached larger parts of the countryside from 1982, economy and agricultural production collapsed and about half of the country's population became dependent on external food relief. Exacerbating this situation, natural hazards (1982-1985 droughts) also affected food production.

As a result, population movements in Mozambique increased with people fleeing violence. Gradually, 
over one third of the population was forced to leave their land, move to cities or military-protected rural areas, or flee abroad as refugees. At the end of the war in 1992, an estimated 1 million Mozambicans had died, about 1.5 million were refugees abroad, and 4 to 5 million had been internally displaced (Raimundo, 2009). These movements and families' choices were also strongly determined by existing kin and social networks, within Mozambique or in South Africa, where many mining migrants had stayed after independence. In Leonzoane, 82 percent of the people had left, either to Massinga, Maputo or South Africa, helped by their networks, but leaving their land and possessions behind.

Within this configuration of drivers, interacting in nuanced ways in war troubled times, new migration patterns emerged. Long term domestic migration increased as a consequence of limitations of displacements due to war. In Leonzoane, 70 percent of households just moved once within Mozambique or to South Africa, with rare home returns; others did a two-step migration, within the country and then to South Africa, with no return, at least until the end of war. Local livelihoods were further impacted upon, with a lesser involvement of males in agriculture and a growing role for the informal sector.

With the end of warfare (1992) and apartheid (1994), a renewed combination of drivers reshaped migration patterns characterized by diversified circular migration led by liberalization and social networks. In this third period, slow economic growth in democratic South Africa did not provide enough jobs for the black low-skilled labour force. High unemployment and the development of poorly paid and informal jobs directly impacted upon migrants from rural Mozambique, since they were likely to compete with unemployed local workers. Foreign miners, hit by large job losses in the 1990s, had no choice but to enter sub-contracting, casualization and undocumented labour.

In Mozambique, the government had turned to a market-oriented economy. The new economic growth occurred with strong inequalities, rising rural poverty, and the broad family farming sector lacking the needed support in traditionally sending rural areas. Migration remained an option for many, but mostly towards the South African informal economy. Despite South Africa's new immigration laws offering more rights to migrants, authorities clearly discouraged permanent immigration and the result was an increase of undocumented migrants.

With peace, people were able to move again - helped by improved infrastructure and communication. Refugees who decided to stay in South Africa or in Mozambican cities consolidated social networks with their relatives in rural areas. Stronger and more complex linkages between places and people led to the expansion of new migration patterns toward a diversity of circular movements. Two-step migration patterns, national and then international, with home returns or short term visits have developed. These profiles are the more mobile and reflect multi-sites patterns, with shifting residences. The numbers of long-term national or international migration have also increased. This comes with new routes towards locations within the traditional mining areas and outside (in the Eastern and Western Cape and KwaZuluNatal provinces).

These renewed patterns of migration are reshaping rural livelihoods as part of adaptation strategies to a liberalized context where informal and volatile labour conditions prevail. They result in increasing livelihoods' differentiation in terms of income and activities, between migrants and non-migrant households - being the poorest - and between migrants.

\subsubsection{Climate change: a misleading determinant but a complex driver of migration}

In the international debate today, in a context where climate change receives a growing attention, climatic events are often pointed as a major determinant of migration. However, rural households' situation with regard to climate change and its possible impact is highly differentiated. Variation mostly depends on their existing economic and social assets and on alternatives offered by their environment, which directly shape their vulnerability. Indeed, depending on their ability to migrate, rural households can be trapped 
and face dire and worsening situations or, on the opposite, can start a new life elsewhere. Migration has been increasingly seen as an adaptive response to the impact of climate change, operating as a buffer and contributing to the resilience of the communities of origin.

The link between climate change and rural migration is complex. It is never unequivocal and several entangled and often self-reinforcing factors are at play. Forecasting rural migration patterns based on climate projections is therefore inaccurate. It often overlooks the complexity of processes and, in practice, it is the result of the combination of climatic events and other natural, social, political and economic factors that affects populations living in already vulnerable and fragile environments.

This is the case of tropical regions, which are particularly vulnerable to climate impacts (IPCC, 2014), and when there is extensive reliance on climate sensitive livelihood activities. In SSA, rural communities still heavily depend on rain-fed crop production (they represent 96 percent of agricultural land in SSA) and on many extractive activities (hunting, fishing, and gathering) for food, water, and energy (wood and charcoal). The slow development of irrigation, the low adaptive capacity of existing farming systems, and the limited institutional capacity to design and implement effective adaptation measures exacerbate the over-reliance on natural factors. As such, climate change can foster food insecurity and SSA is one of the regions that would be the most severely hit (Schlenker and Lobell, 2010), with scenarios projecting a 20 percent increase of malnutrition incidence in 2050 . However, food crises will likely result from a succession of shocks rather than isolated events and from coupling climatic and non-climatic factors.

In SSA, vulnerability is of course exacerbated by poverty. The majority of rural people are poor; many are in extreme poverty, and their ability to cope with external shocks is limited by scarce or nonexistent possibilities for savings. While kinship and social networks could facilitate adaptation strategies - including migration - other factors such as low levels of education or limited access to assets and resources can act as barriers. Some regions of the continent are already facing critical environmental crises. These are places where land pressure is high (like the Ethiopian Highlands or the Great Lakes region) and where the vulnerability is also exacerbated by water shortages (e.g. Northern Nigeria, specific areas of Central Mali and Burkina Faso).

In countries where risk mitigation mechanisms are in place, people can be better equipped to prepare and cope with the adverse impacts of climate change. The adequate provision of private insurance and public goods (social protection) and the government's capacity to answer to basic needs in the aftermath of natural disasters can help people to reconstruct their livelihoods and release pressure on the need to migrate. Similarly, preventive measures aiming at strengthening livelihoods resilience and reducing their sensitivity to climate variability could provide opportunities for people to thrive.

Interventions to tackle the root causes of vulnerability spanning from building climate resilient infrastructures to boosting education and access to information could serve the double purpose of decreasing vulnerability as well as enhancing the positive impacts of migration for resilience building. In most SSA countries, issues such as political instability, bad governance, lack of capacities and limited financial resources prevent an effective use and implementation of similar mechanisms.

Opposite to simplifying causalities, understanding how climate change interacts with other migration drivers appears as a first major step. It requires disentangling the complexity in order to design adaptation strategies that address the root causes of vulnerability and tackle the challenges of climate related migration. Prevention and adaptation finally require development strategies based on collective choices, grounded in possible and desirable visions of the future and possible scenarios. It calls for participatory processes for adequate and efficient design of public policies and implementation of multi- stakeholder actions. 


\section{Conclusion}

The aim of this working paper was to provide an up-to-date review of the literature examining the patterns and drivers of rural migration in Africa, to explore their relation to rural and structural transformation, and therefore feed the current policy debates on migration.

Migration is embedded in the process of structural transformation. Despite regional variation, historical evidence reminds how internal and international mobility of people goes hand in hand with productivity growth, the intersectoral transfer of labour and urbanization. Globally, people have been moving from rural areas to other places, generally cities and sometimes other countries.

Nowadays, the strength of urbanization and the opportunities of urban dynamics continue to fuel ruralurban migration. However, this historical process is challenged. Worldwide, the systemic threats related to climate change and the depletion of natural resources - particularly fossil energy -question the urban growth model and its sustainability, notably related to the negative externalities of metropolization. In the specific context of sub-Saharan Africa, additional structural challenges result from the very unique demographic transition of the region, where population growth fuels massive job needs. This potential is confronted to low diversified economies where the lack of industrialization and the importance of the informal sector, offering many opportunities but with low returns and high vulnerability, limit the absorption capacity of cities and explains the difficulty of poverty alleviation.

As a consequence of this very specific development path, new migration patterns have emerged over the last decades. Beyond the classical one-way rural-urban migration, contemporary African migration is characterised by multidirectional (including rural to rural and urban to rural), more complex and stepwise movements with forms of circular migration that imply double-way, continuous relations of rural migrants with their areas of origin.

These new patterns, by supporting socio-economic linkages within and across space and sectors, are challenging the conventional knowledge on the process of rural change. They reveal that migration is performing a range of socio economic functions far beyond the only transfer of labour from agriculture to others sectors and from rural to urban areas. As such, even if its contribution is most often overlooked, renewed migration dynamics can play a role in SSA structural transformation.

At individual, household and community levels, migration can contribute to rural livelihoods, providing pathways out of poverty, both for migrants and their families staying behind. The support of migrants through either social and cash remittances foster rural diversification with the development of on-farm, off-farm and non-farm activities. It reshapes the characteristics of rural households which are more diversified but also multi-located with members living and circulating between places. At the subnational or territorial level, in a context of increasing access to ICTs and improved transportation, African migration is at the core of new territorial dynamics with multiple and increased rural-urban linkages, contributing to blurring the old rural-urban divide. At the national level, even if their effects are embedded in many other macro-processes of change, migration likely contribute to socio-economic resilience, to entrepreneurship, and to economic growth through initiatives supported by remittances, new information and knowledge.

The decision to migrate is complex and influenced by a myriad of interlinked factors. Considering the role of rural migration in SSA's transformation process, it is crucial to better understand the mechanisms at play and this working paper helps to identify their drivers, their combination and their regional diversity.

Migration is often perceived as an erratic phenomenon largely driven by a desperate move to better-off cities in order to escape poverty, or by forced movement related to adverse local conditions. 
This perception, which partly reflects the traditional "push-pull" model of migration, is insufficient to fully capture the complexity of migration in contemporary Africa. The paper highlights the ambivalent and complex relationships between poverty and migration and reminds the importance of agency, even when migrants face enormous constraints. It takes on board the role of "non-economic", cultural, social and political factors, which not only shape the pattern and direction but also the characteristics of migration flows, including migrants' profiles.

Many migrants are not only "driven" by effective labour demand, but also by perceived economic opportunities and educational or socio-cultural motivations. Migrants have diverse socio economic profiles and different expectations, responding to diverse opportunities according to economic, political and cultural circumstances - changing over time, sometimes under the influence of migration itself. Considering this complexity, the drivers of migration do not work as independent forces. On the contrary, they operate in combination and are part of drivers complexes, which shape the specific form and structure of population movements.

The complexity of rural migration and its role in development processes, which include differentiated outcomes, call for better policy design in order to build on or mitigate their positive or negative consequences. Public policies, by considering the many drivers of migration, can play a direct or indirect role in maximising the benefits and limiting the drawbacks of rural migration, both in places of origin and destination.

Opposite to policy manoeuvring and instrumentality, a conducive approach first requires political commitment to look at migration as an opportunity. It can support and foster economic initiatives in the different regions of a country, and also in countries of destination when international migration is at play which mostly means neighbouring countries in the case of SSA.

It then needs to take on board the new rural-urban linkages and the related territorial dynamics underway supported by renewed migration patterns. Taking advantage of these new trends presents another opportunity for harnessing the potential of a more balanced territorial development. Analysing local assets and specific constraints is a major avenue for identifying adequate development strategies, and existing sectorial policies must be articulated into place-based, integrated territorial strategies - a new approach for development which is gaining momentum (TP4D, 2018). Public action can support private initiatives and the development of employment basins structured by networks of small towns articulated to their surrounding areas and hinterland. It can contribute to reduce the tensions associated to increasing metropolization. Such an approach using the full potential of African migration patterns must be supported by:

1. A significant improvement of the knowledge base in order to deal with the huge existing data gaps about migration and local dynamics. A better understanding is key to better policy making;

2. A reinvestment in strategic thinking including agricultural development models and the respective roles of corporate investment and family farming, and their consequences on employment and rural livelihoods;

3. A better understanding of environmental issues and pressure on natural resources with adequate policy frameworks to support and secure access to land and water;

4. An adequate provision of public goods and infrastructure to foster sectorial growth linkages between agriculture, rural non-farm activities and the development of small towns and provincial cities.

Overall this approach must be consolidated by improved participation of local stakeholders, migrants, nonmigrant and migrant households, facilitated by information sharing and discussion of what could be the plausible futures of rural areas. It can definitely help to avoid marginalization and help rural migrants to decide why and where they will migrate, by choice and not by necessity. 


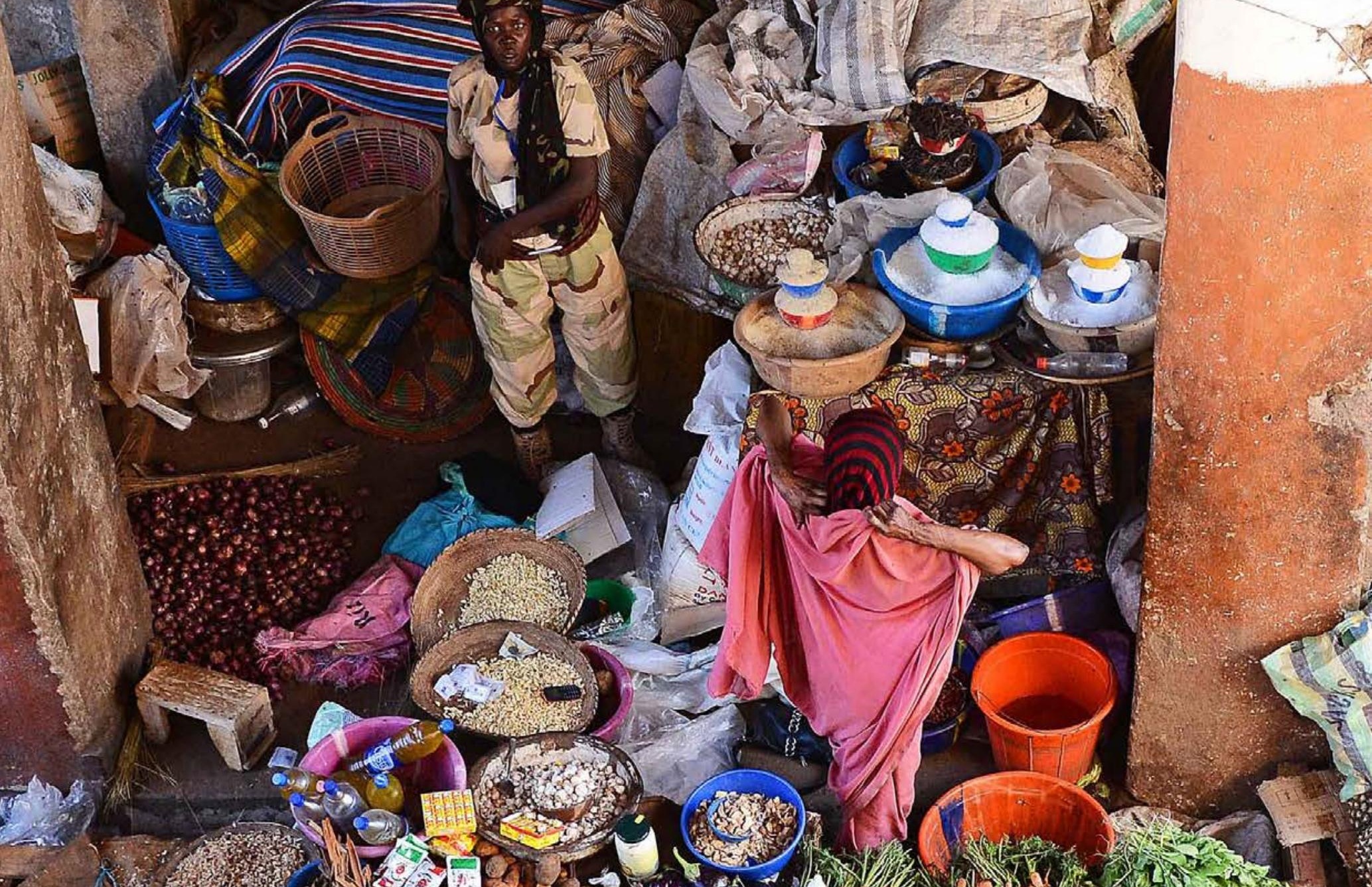

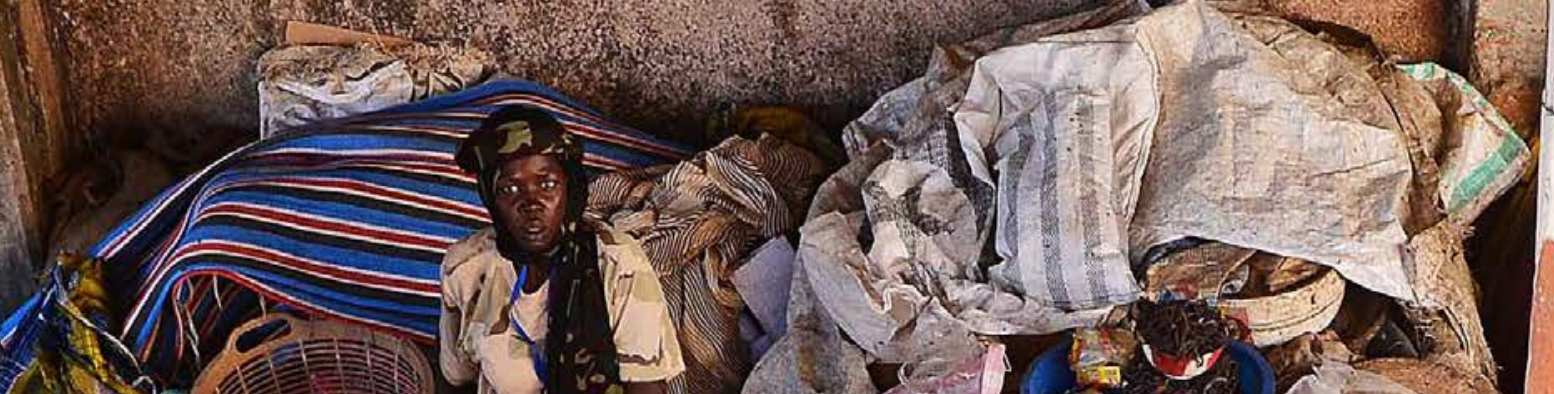

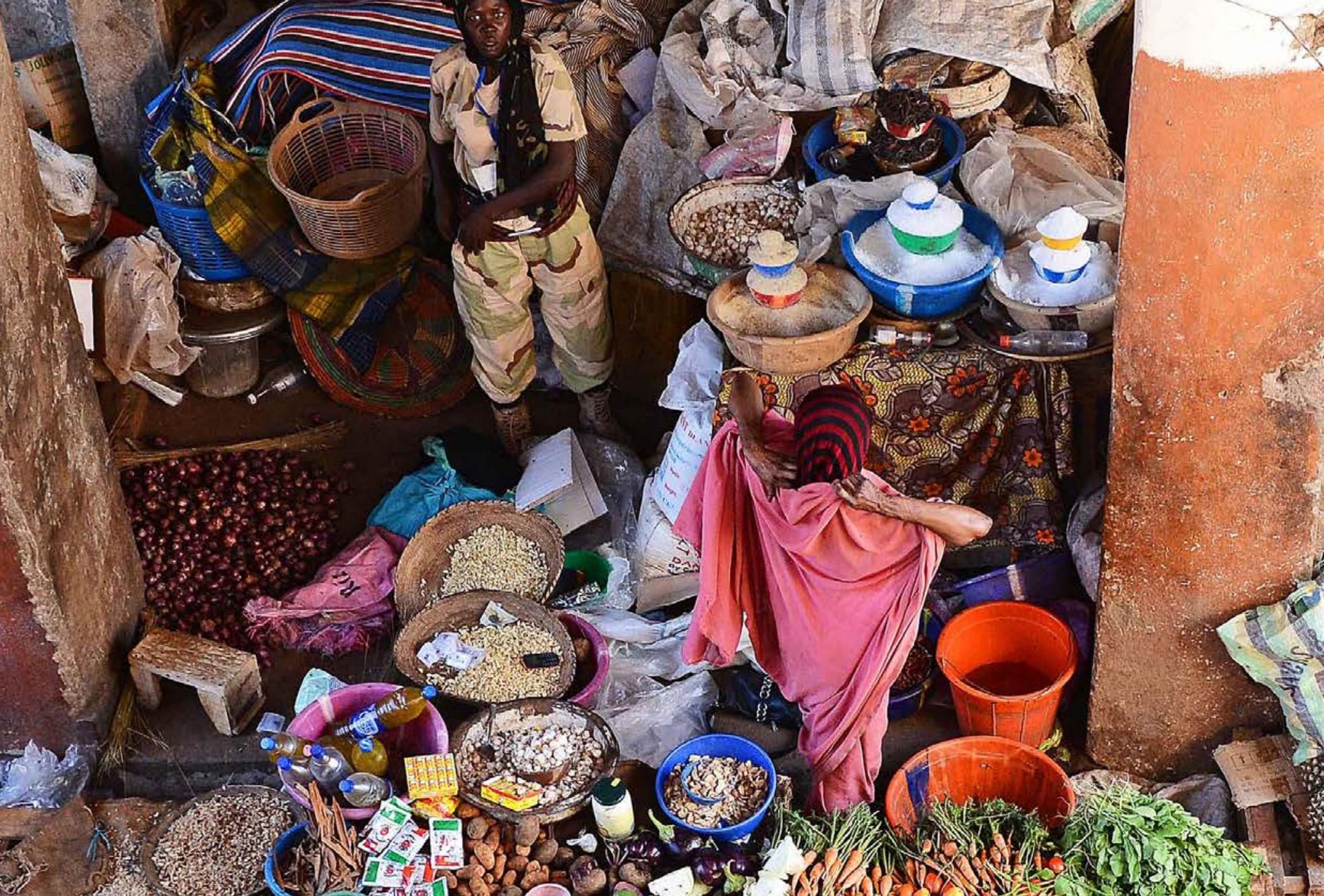
3.

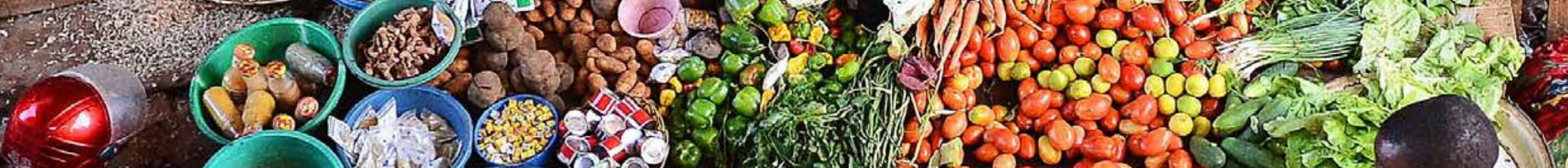

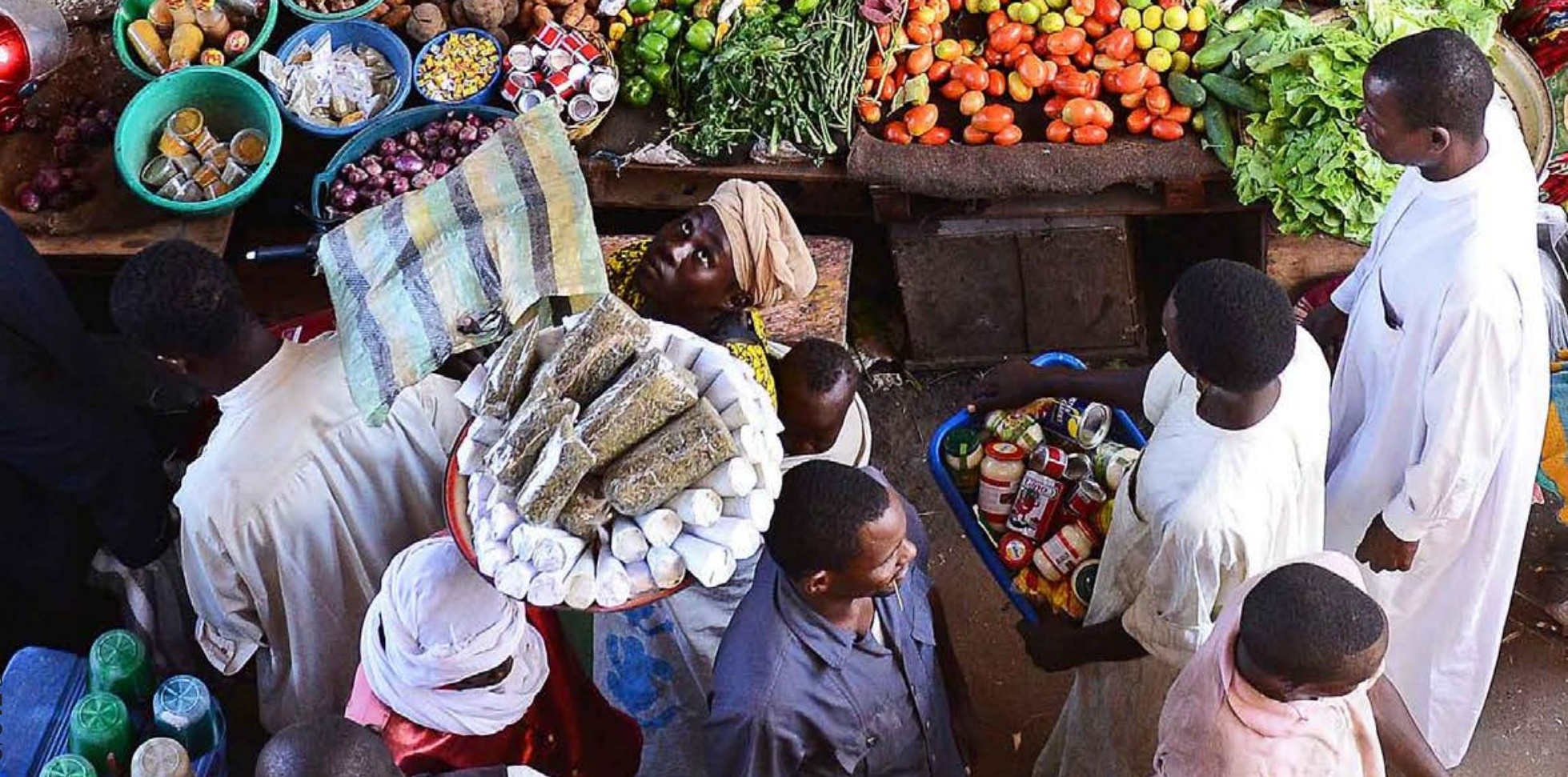




\section{References}

Abrahamson, H., \& Nilsson, A. 1995. Mozambique the troubled transition, from socialist construction to free market capitalism. London, Zed Books.

Adepoju, A. 1995a. Emigration dynamics in Sub-Saharan Africa. International Migration 33.

Adepoju, A. 1995b. Migration in Africa: an overview. In: Baker, J., Aina, T. (Eds.), The Migration experience in Africa, pp. 87-108. Sweden, Nordiska Afrikainstitutet.

Adepoju, A. 2000a. Issues and recent trends in international migration in Sub-Saharan Africa. International social science journal, 52, $3 / 165$, pp. 384-396.

Adepoju, A. 2000b. Regional integration, continuity and changing patterns of intraregional migration in SubSaharan Africa. In: Siddique, M.A.B. (Ed.), International migration into the 21st century: Essays in honour of Reginald Appleyard. Edward Edgar Publishing, Aldershot.

Adepoju, A. 2005. Migration in West Africa. A paper prepared for the Policy Analysis and Research Programme of the Global Commission on International Migration. Human Resources Development Centre, Lagos, Nigeria, p. 24.

African Development Bank. 2014. Taking Africa's Irregular Migrants into Account: Trends, Challenges and Policy Options. African Economic Brief. Volume 5, Issue 1, 16p.

African Development Bank, Organisation for Economic Co-operation and Development, United Nation Development Programme. 2015. African Economic Outlook 2015: Regional Development and Spatial Inclusion. pp. 352. OECD, Paris.

Afolayan, A. A. 1988. Immigration and Expulsion of ECOWAS Aliens in Nigeria. The International Migration Review, Vol. 22, No. 1, pp. 4-27.

Agresti, A. 2002. Categorical Data Analysis. New York: Wiley-Interscience.

Akkoyunlu S. 2013. The Potential of Rural-urban Linkages for Sustainable Development and Trade. NCCR Working Paper No 2013/37, 41p.

Amin, S. 1972. Underdevelopment and dependence in Black Africa-origins and contemporary forms. The Journal of Modern African Studies, 10 (04): 503-524.

Amsden, A. 2001. The rise of "the rest": Challenges to the West from late-industrializing economies. New York, Oxford University Press.

Amselle, J. L., Aghassian, M. et al. 1978. Les migrations africaines. Réseaux et processus migratoires, Paris, Maspero.

Andersson, R. 2014. Illegality, Inc.: Clandestine Migration and the Business of Bordering Europe. University of California Press, Berkeley.

Arango, J. 2000 . Explaining migration: a critical view. International Social Science Journal 52(165): 283-96.

Awumbila, M., Kofi Teye, J., Litchfield, J., Boakye-Yiadom, L., Deshingkar, P., Quartey, P. 2015. Are Migrant Households better off than Non-Migrant Households? Evidence from Ghana, Migrating out of poverty. research programme consortium, Working Paper 28, 48 pp.

Azam, J. P., \& Gubert, F. 2006. Migrants' remittances and the household in Africa: a review of evidence. Journal of African Economies, 15(suppl_2): 426-462.

Ba, C.O., Bourgoin, J., Diop, D. 2018. Les migrations rurales dans la dynamique migratoire Sénégalaise. La fluidité des mobilités internes en réponse aux contraintes locales. Rome, FAO and CIRAD, 24 pp.

Bakewell, 0., de Haas, H. 2007. African Migrations: Continuities, Discontinuities and Recent Transformations. In: Chabal, P., Engel, U., de Haan, L. (Eds.), African Alternatives. Brill, Leiden, pp. 95-118.

Bakewell, 0. 2007. Keeping Them in their Place: The Ambivalent Relationship between Development and Migration in Africa. IMI Working Paper 8, Oxford: International Migration Institute. 
Bakewell, 0. 2010. Some reflections on structure and agency in migration theory. Journal of Ethnic and Migration Studies, 36 (10): 1689-708.

Bakewell, 0. 2011. Conceptualizing causality in migration processes. New approaches for researching the determinants of migration processes: ESF strategic workshop on migration research. 29-30 September, University of Oxford: International Migration Institute and European Science Foundation 2011.

Balen, J., McManus, D. P., Li, Y. S., Zhao, Z. Y., Yuan, L. P., Utzinger, J., \& Zhou, J. 2010. Comparison of two approaches for measuring household wealth via an asset-based index in rural and peri-urban settings of Hunan province, China. Emerging themes in epidemiology, 7(1): 7.

Berdegué, J. A., Proctor, F. J. 2014a. Cities in the Rural Transformation. Working Paper Series N 122. Working Group: Development with Territorial Cohesion. Territorial Cohesion for Development Program. Rimisp, Santiago, Chile.

Berdegué, J. A., Proctor, F. J., Cazzuffi, C. 2014b. Inclusive Rural-Urban Linkages. Working Paper Series $N^{\circ}$ 123. Working Group: Development with Territorial Cohesion. Territorial Cohesion for Development Program. Rimisp, Santiago, Chile.

Bijak, J., Disney, G., \& Wiśniowski, A. 2015. How to forecast international migration. ESRC Centre for Population Change, Briefing 28.

Bilger, V., Kraler, A. (Eds.). 2005. African migrations: historical perspectives and contemporary dynamics. Stichproben, Vienna.

Black, R., King, R. 2004. Editorial Introduction: Migration, Return and Development in West Africa. Population, Space and Place 10, 75-83

Black, R., Crush, J., Peberdy, S. 2006. Migration and development in Africa: an overview. African Migration \& development series, $n^{\circ} 1$, Cape Town: Southern African Migration Program, $159 \mathrm{p}$.

Black, R., Kniveton, D., Skeldon, R. et al. 2008. Demographics and Climate Change: Future Trends and their Policy Implications for Migration. Development Research Centre on Migration, Globalisation and Poverty. University of Sussex, Brighton, UK.

Black, R., Adger, W., Arnell, N., Dercon, S., Geddes, A., Thomas, D. 2011. The Effect of Environmental Change on Human Migration. Global Environmental Change, 21(1): 3-11.

Bilsborrow, R.E. 2002. Migration, Population Change, and the Rural Environment. Population, Environmental Change, and Security Working Paper No. 2. Ann Arbor and Washington, DC: Population and Environment Fellows Program, University of Michigan and Woodrow Wilson International Center.

Boswell C. 2008. Combining economics and sociology in migration theory. Journal of Ethnic and Migration Studies, 34(4): 549-66.

Bourgeois, R. 2015. What Future for Rural Areas? Seven plausible rural transformations. Development 58 (2-3), pp. 177-186.

Bourgeois, R. 2017. Unpredictable but manageable futures. In Mercandalli S. (ed.), Losch B. (ed.). Rural Africa in motion. Dynamics and drivers of migration South of the Sahara. Rome, FAO, CIRAD, p. 46-47.

Boyd, M. 1989. Family and Personal Networks in International Migration: Recent Developments and New Agendas. International Migration Review, 23(3): 638-670.

Brock, L. 1989. From Kingdom to colonial district: a political economy of social changes in Gazaland, southern Mozambique, 1870-1930. Northwestern University, Microfilms International.

Bryceson, D. F. 2002. The Scramble in Africa: Reorienting Rural Livelihoods, World Development, 30(5), pp. 725-739.

Carling, J., Collins, F. 2017. Aspiration, desire and drivers of migration Journal of Ethnic and Migration Studies, DOI: 10.1080/1369183X.2017.1384134.

Carling, J., Schewel, K. 2017. Revisiting Aspiration and Ability in International Migration. Journal of Ethnic and Migration Studies.

Carling, J. Talleraas, C.. 2016. Root Causes and Drivers of Migration. PRIO Paper, Peace Research Institute, Oslo. 
Castagnone, E. 2011. Bridging the gap between qualitative and quantitative research methods: the case of biographical approach. New approaches for researching the determinants of migration processes: ESF strategic workshop on migration research. 29-30 September, University of Oxford: International Migration Institute and European Science Foundation.

Castles, S. 2008. Development and Migration - Migration and Development: What comes first?. Social Science Research Council Conference, Migration and Development: Future Directions for Research and Policy. O. U. International Migration Institute.

Castles, S. 2010. Understanding Global Migration: A Social Transformation Perspective. Journal of Ethnic and Migration Studies, 36, No. 10, pp. 1565-1586.

Castles, S. 2011. Methodology and Methods: Conceptual Issues. In: African Migration Research: Innovative Methods and Methodologies, M. Berriane and de Haas, H. (eds.). 2011.

Castles, S. 2013. The Forces Driving Global Migration. Journal of Intercultural Studies, 34 (2)

Castles, S. and M. J. Miller. 2009. The Age of Migration. Basingstoke and London, Macmillan.

Chamberlin, J.; Jayne, T.S., Headey, D. 2014. Scarcity amidst abundance? Reassessing the potential for cropland expansion in Africa. Food Policy, 48(0), pp. 51-65.

Chant, S. 1998. Households, gender and rural-urban migration: reflections on linkages and considerations for policy, Environment and Urbanization, 10, (1), pp. 5-21.

Chatel, C., Imbernon, J., Moriconi-Ebrard, F. 2006. Megacities and archipelagos: an emerging urban framework. In Pesche D., Losch B., Imbernon J. (eds.). 2016. A new emerging rural world: An overview of rural change in Africa. 2nd edition, Cirad, Nepad, Montpellier.

Chapman, M. and R. M. Prothero. 1983. Themes on Circulation in the Third World. International Migration Review, 17, pp. 597-632

Charrière, F., Frésia, M. 2008. L'Afrique de l'Ouest comme espace migratoire et espace de protection. UNHCR, Dakar, Sénégal.

Chen, N., Valente, P. and Zlotnik, H. 1998. What do we know about recent trends in urbanization?, in M. Bilsborrow (ed.) Migration, Urbanization, and Development: New Directions and Issues. Massachusetts, United Nations

Chort, I., de Vreyer,P., Zuber, T. 2018. Enduring Gendered Mobility Patterns in Contemporary Senegal. 2018. hal-02141053

Christiaensen, L. and Todo, Y. 2014. Poverty Reduction During the Rural-Urban Transformation. The Role of the Missing Middle. World Development, 63: 43-58.

Clemens, M. 2014. Does Development Reduce Migration?Working Paper, 359. Center for Global Development, Washington, DC.

Collins, F. L. 2017. Desire as a Theory for Migration Studies: Temporality, Assemblage and Becoming in the Narratives of Migrants. Journal of Ethnic and Migration Studies, pp. 964-980.

CNUCED. 2018. Le développement économique en Afrique. Rapport 2018. Les migrations au service de la transformation structurelle. United Nations, New York et Genève, 2018, pp. 212.

Cooper, F. 2002. Africa since 1940: The past of the present. Cambridge University Press, Cambridge.

Córdova, A. 2009. Measuring relative wealth using household asset indicators and principal component analysis (PCA). Insights Series, (6).

Cramer C. and Pontara N. 1998. Rural Poverty and Poverty Alleviation in Mozambique: What's Missing from the Debate?. The Journal of Modern African Studies, 36 (1): 101-138.

Cwerner, S. B. 2001. The Times of Migration. Journal of Ethnic and Migration Studies, 27(1): 7-36.

Dator, J. 2009. Alternative Futures at the Manoa School. Journal of Futures Studies, 14(2): 1-18. Retrieved from http://www.futures.hawaii.edu/publications/futures-studies/AltFuturesManoa2009.pdf

David, H. A., \& Gunnink, J. L. 1997. The paired test under artificial pairing. The American Statistician, 51(1): 9-12. 
De Brauw, A., Mueller, V. and H. K. Lee. 2014. The role of rural-urban migration in the structural transformation of Sub-Saharan Africa. World Development 63: 33-4

De Bruijn, M., van Dijk, R., Foeken, D. 2001. Mobile Africa: Changing Patterns of Movement in Africa and Beyond. Brill, Leiden. Boston.

De Haan A. 1999. Livelihoods and poverty: the role of migration - a critical review of the migration literature. Journal of Development Studies, 36(2), pp. 1-47.

De Haan, A. 2006. Migration in the Development Studies Literature Has It Come Out of Its Marginality?. UN University WIDER Research Paper (19). p28.

De Haan A., Yaqub S. 2010. Migration and poverty: Linkages, knowledge gaps and policy implications. In Hujo K. and Piper N. (eds), South-South Migration-implications for social policy and development. Palgrave Macmillan, pp. 190-219. London and Basingstoke.

De Haas, H. 2010a. Migration and development, a theoretical perspective. International Migration Review, 44(1): 41.

De Hass, H. 2010b. Migration transitions: a theroretical and empirical inquiry into the developmental drivers of international migration. International Migration Institute IMI Working Paper 24 (DEMIG Project Paper 1), University of Oxford: International Migration Institute.

De Haas, H. 2011a. Background Note. New approaches for researching the determinants of migration processes: ESF strategic workshop on migration research. University of Oxford: International Migration Institute and European Science Foundation, 29-30 September 2011. 1-6.

De Haas, H. 2011 b. The determinants of international migration-conceptualising policy, origin and destination effects. DEMIG project Working Paper 2, IMI, Oxford: Oxford University, 35 p.

De Haas, H. and S. Vezzoli. 2011. Leaving Matters: The Nature, Evolution and Effects of Emigration Policies. IMI Working Paper 34 (DEMIG Project Paper 4), University of Oxford: International Migration Institute.

Delaunay V., Sauvain C. et al. 2016. La migration temporaire des jeunes au Sénégal. Un facteur de résilience des sociétés rurales sahéliennes?. Afrique Contemporaine, 259:75-94

Dinbabo, M.F., Mensah C., and Belembeba, N. 2017. Diversity of rural migrants' profiles. In: Mercandalli S., Losch B. (eds), Dynamics and drivers of migration South of the Sahara. Rome, Fao-Cirad, pp. 24-25

Elder, S., de Haas, H., Principi, M., Schewel, K. 2015. Youth and rural development: Evidence from 25 school-to- work transition surveys. Work4Youth Publication Series, $n^{\circ} 29$, Geneva: ILO, 78 p. Ellis, 2003; A Livelihoods Approach to Migration and Poverty Reduction, Paper Commissioned by the Department for International Development (DFID).

Ellis, F. 2000. Livelihoods, Diversification and Agrarian Change, Rural Livelihoods and Diversity in Development Countries. Oxford University Press, New York.

Ellis, F., and Freeman, H.A. 2004. Rural Livelihoods and Poverty Reduction Strategies in Four African Countries. Journal of Development Studies, 40(4): 1- 30

Estruch, E., Van Dijck, L., Schwebel, D., Rrandriamamonjy, J. 2019. Youth mobility and its role in structural transformation in Senegal. In: Mueller V. and Thurlow J. (eds). Youth and jobs in rural Africa. Beyond stylised facts. IFPRI - Oxford University Press, pp 251-275.

Evans, H.E. 1990. Rural-urban linkages and structural transformation. Discussion Paper. Washington, DC: Infrastructure and Urban Development Department, World Bank, 71.

Erdal, M. B., and C. Oeppen. 2017. Forced to Leave? The Discursive and Analytical Significance of Describing Migration as Forced and Voluntary. Journal of Ethnic and Migration Studies.

Faist, T. 1997. The crucial meso-level. In T. Hammar, G. Brochmann, K. Tamas and T. Faist (eds.), International Migration, Immobility and Development. Oxford: Berg.

FAO. 2016a. Addressing rural youth migration at its root causes: a conceptual framework. Rural Employment Knowledge Material. Rome. pp 74

FA0. 2016b. Migration, agriculture and rural development: Addressing the root causes of migration and harnessing its potential for development. Rome. pp 20. 
FAO. 2017. Evidence on Internal and International Migration Patterns in Selected African Countries. FAO, Rome.

FAO. 2018. State of food and agriculture. Migration, agriculture and rural development. Rome, pp. 197

First, R., Forjaz, M., Manghezi, A. 1998. O mineiro moçambicano. Um estudo sobre exportaçao de mão de obra em Inhambane. Maputo: Centro de Estudos Africanos (UEM), pp. 242

Filmer, D., \& Pritchett, L. H. 2001. Estimating wealth effects without expenditure data-or tears: an application to educational enrolments in states of India. Demography, 38(1): 115-132.

Fei, J. C. H. and G. Ranis. 1964. Development of the Labour Surplus Economy: Theory and Policy. Homewood, IL: Richad D. Irwin for the Economic Growth Center, Yale University.

Flahaux, M.L., De Haas, H. 2016. African migration: trends, patterns, drivers. Comparative Migration Studies, 4(1): 25

Fox, S. 2012. Urbanization as a global historical process: Theory and evidence from sub-Saharan Africa. Population and Development Review. 38, pp. 285-310.

Gemenne, F. 2011. Why the numbers don't add up: A review of estimates and predictions of people displaced by environmental changes. Global Environmental Change, 21, S41-S49. https://doi.org/10.1016/j. gloenvcha.2011.09.005

Global Forum on Agriculural Research. 2014. A glossary of terms commonly used in Futures Studies. GFAR, Rome, 29p. Retrieved from http://www.fao.org/docs/eims/upload//315972/Glossary of Terms.pdf

Giraud, J.N. 1996. L'inégalité du monde : Économie du monde contemporain. Paris, Gallimard.

Guengant J.-P., May, J. 2013. African demography. Global Journal of Emerging Market Economies, 5(3): 215-67.

Governo do Moçambique. 1928. Diario do Governo, 'Convenção entre o Governo da Republica portuguesa e o Governo da União da Africa do Sul'. Mozambique

Gwen, A. 1976. Types, Processes and Policy Implication of Various Migrations in Western Cameroon. The Dynamics of Migration: Internal Migration and Fertility. Interdisciplinary Communication Program, Smithsonian Institution.

Harris, J. and Todaro, M. P. . 1970. Migration, unemployment and development: a two sector analysis. The American Economic Review, 60(1): 126-142.

Hatton, T.J. and Williamson, G.W. 2005. Global migration and the world economy: Two centuries of policy and performance. Cambridge, MA, MIT Press.

Herrera, C. and Sahn, D. 2013. Determinants of Internal Migration Among Senegalese Youth. London: DFID, IZA working paper, $45 \mathrm{p}$.

Hilbe, J.M. 2009. Logistic Regression Models. Chapman \& Hall/CRC Press

International Fund for Agricultural Development. 2010. Rural Poverty Report 2011. New Realities, New Challenges: New Opportunities for Tomorrow's Generation. Rome, IFAD, 319 p.

IMI, ESF. 2011. New approaches for researching the determinants of migration processes: ESF strategic workshop on migration research. 29-30 September 2011, International Migration Institute, University of Oxford, 19p.

International Organization for Migration. 2008. Irregular migration. World Migration 2008: Managing Labour Mobility in the Evolving Global Economy, United Nations publication, Geneva.

International Organization for Migration. 2011. Glossary on Migration. International Migration Law n²5. 2nd edition. Richard Perruchoud and Jillyanne Redpath-Cross, eds. IOM 2011. 118p

IPCC. 2014. Climate Change 2014: Impacts, Adaptation, and Vulnerability. Part B: Regional Aspects. Contribution of Working Group II to the Fifth Assessment Report of the Intergovernmental Panel on Climate Change. Barros, V.R., C.B. Field, D.J. Dokken, M.D. Mastrandrea, K.J. Mach, T.E. Bilir, M. Chatterjee, K.L. Ebi, Y.O. Estrada, R.C. Genova, B. Girma, E.S. Kissel, A.N. Levy, S. MacCracken, P.R. Mastrandrea, and L.L.White (eds.)]. Cambridge University Press: United Kingdom \&New York, 688 p. 
Johnston, B.F.; Kilby, P. 1975. Agriculture and structural transformation: Economic strategies in latedeveloping countries. Oxford, Oxford University Press.

Kafle, K, Benfica, R., Winter, P. 2018. Does relative deprivation reduce migration? Evidence from Subsaharan Africa. IFAD research series 21, $42 \mathrm{p}$.

King, R., and Skeldon, R. 2010. Mind the Gap! Integrating Approaches to Internal and International Migration. Journal of Ethnic and Migration Studies, 36(10), 1619-46.

Knoll, A., Rampa, F., Torres, C., Bizzotto Molina, C, and Cascone, N. 2017. The nexus between food and nutrition security, and migration. Clarifying the debate and charting a way forward. ECDPM working paper $112,56 p$.

Knoll, A. and Sherriff, A. 2017. Making Waves: Implications of the irregular migration and refugee situation on Official Development Assistance spending and practices in Europe. A study of recent developments in EU institutions, Denmark, Germany, the Netherlands and Sweden. Rapport 2017:01. Stockholm: EBA

Laws, E. and Avis, W. 2017. Rural Migration (Literature Review). Birmingham, UK: GSDRC, University of Birmingham.

Le Bris, E., Marie, A., Osmont, A., Sinou, A. 1985. Résidence, stratégies et parenté dans les villes africaines. Les annales de la recherche urbaine, 25: 13-30.

Lee, E. S. 1966. A theory of migration. Demography, 3(1): 47-57.

Levitt, P. 2001. The Transnational Villagers. Berkeley and Los Angeles: University of California Press.

Lewis, A. W. 1954. Economic development with unlimited supplies of labour. Manchester School of Economics and Social Studies, 22, 139-91

Losch, B. 2005. Côte d'Ivoire. In: Mehler Andreas (ed.), Melber Henning (ed.), van Walraven Klass (ed.). Africa yearbook 2004: politics, economy and society South of the Sahara. Leyde: Brill, p. 61-69. (Africa Yearbook, 1).

Losch, B. 2015. Can we still only think 'rural'? Bridging the rural-urban divide as a necessary step for rural transformation in a globalized world. Development, 58(2-3): 169-176.

Losch, B. 2016a. The need for a paradigm shift towards territorial development in sub-Saharan Africa. Working Paper Series N 185. Santiago, Chile: Rimisp.

Losch, B. 2016b. Structural transformation to boost youth labour demand in sub-Saharan Africa: The role of agriculture, rural areas and territorial development. Employment Working Papers No.204, Geneva: ILO, 70 p.

Losch, B., Freguin-Gresh, S., White, E.T. 2012. Structural transformation and rural change revisited: challenges for late developing countries in a globalizing world. Washington, DC: World Bank, $301 \mathrm{p}$.

Losch, B., Minsat A., Giordano T., Mercandalli S., et al. 2015. Regional development and spatial inclusion. In: African Economic Outlook 2015: regional development and spatial inclusion. pp. 133-231. OECD, Paris

Losch, B., Magrin, G. 2016. Rural and urban densification Continues. In: Pesche D., Losch B., Imbernon J. (eds.). A new emerging rural world - an overview of rural change in Africa. pp 16-17, Montpellier: Cirad, Nepad.

Mabogunje, A. L. 1970. Systems approach to a theory of rural-urban migration. Geographical Analysis 2(1): $1-18$.

Maddison, A. 2010. Statistics on World Population, GDP and Per Capita GDP, 1-2008 AD. The MaddisonProject Website, University of Groningen.

Mc Dowell, C. and de Haan, A. 1997. Migration and Sustainable Livelihoods: A Critical Review of the Literature. Institute of Development Studies Working Paper, (65). p29.

Magrin, G. 2013. Voyage en Afrique rentière. Une lecture Géographique des Trajectoires du Développement. Paris: Publications de la Sorbonne.

Magrin, G., Losch, B. 2013. Empty land? Pressure on resources and development choices. In Losch B., Magrin G., Imbernon J. (eds.). A new emerging rural world: An overview of rural change in Africa. Montpellier: CIRAD. 
Ma Mung, E., Kamel Doraï, M., Hily, M.-A., Loyer, F. 1998. La circulation migratoire, bilan des travaux. Synthèse. Migrations études, ADRI (Aggence pour le développement des relations interculturelles), pp. 1-12.

Makinwa-Adebusoye, P.K. 1983. Demographic Aspects of Climatic Changes in Africa. Journal of Society, Culture and Environment 2, 15-26.

Makinwa-Adebusoye, P.K. 2006. Geographic Labor Mobility in Sub-Saharan Africa. International Development Research Centre, Ottawa.

Mander, H. and Sahgal, G. 2015. Internal Migration in India: Distress and Opportunities. A Study Commissioned by Dan Church India.

Markowski, CA and Markowski, EP. 1990. Conditions for the Effectiveness of a Preliminary Test of Variance. The American Statistician. 44 (4): 322-326.

Massey, D. S. 1990. Social structure, household strategies, and the cumulative causation of migration. Population Index, 56: 3-26.

Massey D., J. Arango, et al. 1993. Theories of international migration: a review and appraisal. Population and Development Review, 19 (3): 431-466.

Massey, D., Arango, J., Hugo, G., Kouaouci, A., Pellegrino A., \& Edward Taylor, J. 1998. Contempory theories of international migration. In: Worlds in Motion: Understanding International Migration at the end of the Millenium. D. S. Massey, J. Arango, G. Hugo, A. Kouaouci, A. Pellegrino, and J. E. Taylor, Oxford, Clarendon Press. p15-69.

Mckenzie, D. and Rapoport, H. 2007. Network effects and the dynamics of migration and inequality: Theory and evidence from Mexico. Journal of Development Economics, 84(1): 1-24.

Mercandalli S. 2015. Migrations et recompositions des stratégies socio-économiques des familles rurales au Mozambique : une lecture institutionnelle des circulations contemporaines. Mondes en développement, 172(4): 33-52.

Mercandalli S. 2017. Prevalent, contrasted intra-African migration patterns and new territorial dynamics. In: Mercandalli S. (ed.), Losch B. (ed.). Rural Africa in motion. Dynamics and drivers of migration South of the Sahara. Rome: FAO, CIRAD, p. 22-23.

Mercandalli, S., Anseeuw, W. 2014. Migrations et stratégies des familles mozambicaines : réflexions pour une politique intégrée de développement rural. Tiers Monde, 220 (4): 61-79.

Mercandalli, S., Nshimbi, C.C. 2016. Migration dynamics: contrasted patterns, diversity and potentials. In Pesche D., Losch B., Imbernon J. (eds.), A New Emerging Rural World - An Overview of Rural Change in Africa. Montpellier: CIRAD, NEPAD, 76 p.

Mercandalli, S., Anseeuw, W. 2017. Migration and resilience of rural households' livelihoods in the face of changing political and economic context: the case of south Mozambique (1900-2010). African Studies, 76(2): 221-242.

Mercandalli, S. and Losch, B., eds. 2017. Rural Africa in motion. Dynamics and drivers of migration South of the Sahara. Rome, FAO and CIRAD. 60 p.

Mercandalli S., Losch B., Rapone C., Bourgeois R., Khalil C.A. 2017. Rural migration and the new dynamics of structural transformation in sub-Saharan Africa. In: Mercandalli Sara. (ed.), Losch Bruno (ed.). Rural Africa in motion. Dynamics and drivers of migration South of the Sahara. Rome: FAO, CIRAD, p. 14-17.

Mercandalli, S. and Losch, B., eds. 2018. Une Afrique rurale en mouvement. Dynamiques et facteurs des migrations au sud du Sahara. Rome, FAO et CIRAD. 60 p.

Milbourne, P., Kitchen, L. 2014. Rural mobilities: Connecting movement and fixity in rural places. Journal of Rural Studies, 34: 326-336,

Mora, J. and Taylor, J.E. 2006. Determinants of migration, destination, and sector choice: Disentangling individual, household, and community effects. In: Ozden Ç. and Schiff, M. (eds.). International migration, remittances and the brain drain. Washington D.C.: World Bank and Palgrave Macmillan: 21-51.

Mutandwa, E., Kanuma Taremwa, N., K., Uwimwana, P., et al. 2011. An Analysis of the Determinants of Rural to Urban Migration among Rural Youths in Northern and Western Provinces of Rwanda. Rwanda Journal, 22(B): Social Sciences. 
Ndiaye, M., Robin, N. 2010. Les migrations internationales en Afrique de l'Ouest. Une dynamique de régionalisation renouvelée. Hommes et migrations 1286-1287.

Nkamleu, G.B., Fox, L. 2006. Taking Stock of Research on Regional Migration in Sub-Saharan Africa. MPRA Paper p. 59.

Nshimbi, C.C., Moyo, I.. 2017. Migration, Cross-border Trade and Development in Africa: Exploring the role of non-state actors in the SADC region. Series: Palgrave Studies of Sustainable Business in Africa.

Nyberg-Sorensen, N., Van Hear, N., Engberg-Pedersen, P. 2002. The migration development nexus evidence and policy options state-of-the-art overview. International Migration, 40(5): 3-47.

OECD. 2009. The Future of International Migration to OECD Countries. OECD, Paris, https://doi. org/10.1787/9789264064126-en.

OECD. 2016. Recent trends in international migration. In Perspectives on Global Development 2017: International Migration in a Shifting World, pp. 79-102, OECD, Paris.

Oucho, J.O. 1995. Emigration dynamics of Eastern African Countries. International Migration 33: 31-53.

Papademetriu, D., Martin, P. L. 1991. The Unsettled Relationship, Labor Migration and Economic Development Contributions in Labor Studies. New York, Connecticut London, Greenwood Press.

Pesche, D., Losch, B., Imbernon, J. 2016. A new emerging rural world: An overview of rural change in Africa. 2nd edition, Montpellier: Cirad, Nepad.

Plaza, S., Navarrete, M., \& Ratha, D. 2011. Migration and remittances household surveys in Sub-Saharan Africa: methodological aspects and main findings. World Bank, Washington, DC.

Potts, D. 2012. Challenging the myths of urban dynamics in Sub-Saharan Africa: the evidence from Nigeria. World Development, 40(7), pp. 1382-1393.

Potts, D. 2013. Rural-Urban and Urban-Rural Migration Flows as Indicators of Economic Opportunity in SubSaharan Africa: What Do the Data Tell Us?. Migrating Out of Poverty Research Programme Working Paper, Brighton: University of Sussex, $40 \mathrm{p}$.

Pritchett, L. 2006. Let Their People Come-Breaking the Gridlock on Global Labor Mobility. Washington, DC: Center for Global Development.Graem, H., 2013, What we know about circular migration and enhanced mobility, MPI policy briefs, 11p.

Ravenstein, E. G. 1885. The laws of migration. Journal of the statistical society of London, 48(2): 67-235.

Raimundo, I.M. 2009. International Migration Management and Development in Mozambique: What Strategies?. International Migration, 47(3): 93-122.

Regional Mixed Migration Secretariat (RMMS), International Migration Institut. 2012. Global migration futures: Using scenarios to explore future migration. In the Horn of Africa \& Yemen. 52p, Oxford. https:// www.migrationinstitute.org/publications/global-migration-futures-using-scenarios-to-explore-futuremigration-in-the-horn-of-africa-yemen/@@download/file

Ruyssen, I. \& Rayp, G. 2014. Determinants of Intraregional Migration in Sub-Saharan Africa 1980-2000. Journal of Development Studies, 50(3): 426-443, DOI:10.1080/00220388.2013.866218

Sabates-Wheeler, R., Sabates, R., and Castaldo, A. 2008. Tackling poverty-migration linkages: Evidence from Ghana and Egypt. Social Indicators Research 87(2): 307-328.

Sauvain-Dugerdil, C., Preiswerk, Y. 1993. Vers un ailleurs prometteur. in (eds) L'émigration, une réponse universelle á une situation de crise. Cahier du PIUED, pp 15-26

Schlenker, W., Lobell, D.B. 2010. Robust negative impacts of climate change on African agriculture. Environmental Research Letters, 5(1), 8 p.

Skeldon, R. 2008. Migration and development, United Nations Expert Group Meeting on International Migration and Development in Asia and the Pacific Bangkok, Thailand. United Nations Economic and Social Commission for Asia and the Pacific, Population Division, DESA.

Skeldon, R. 1997. Migration and development: a global interpretation. London, Harlow, Essex, Haddison Wesley Longman.

Skeldon, R. 1990. Population Mobility in Developing Countries: A Reinterpretation. London: Belhaven. 
Stark, 0. 1991. The Migration of Labor. Oxford: Blackwell.

Steel, G., Birch-Thomsen, T., Cottyn, T., Lazaro, E., Mainet, H., Mishili, F., van Lindert, P. 2018. Multi-activity, Multi-locality and Small-Town Development in Cameroon, Ghana, Rwanda and Tanzania. European Journal of Developemnt Research, 31:12-33.

Suttie, D. and Vargas Lindus, R. 2016. Migration and transformative pathways. A rural perspective. IFAD research series $02,36 \mathrm{pp}$.

Tacoli, C. 2001. Urbanisation and migration in Sub-Saharan Africa: changing patterns and trends. In Bruijn, M.E.de; Dijk, R.A.van; Foeken, D.W.J. (eds), Mobile Africa: Changing Patterns of Movement in Africa and Beyond, Leiden: Brill, pp. 141-152.

Tacoli, C. 2002. Changing Rural-Urban Interactions in Sub-Saharan Africa and their Impacts on Livelihoods: A Summary. IIED Working Paper Series on Rural-Urban Interactions and Livelihood Strategies 7, London: IIED, $47 \mathrm{p}$.

Tschirley, D., and Reardon, T. 2015. Impact on Employment and Migration of Structural and Rural Transformation. Paper prepared for IFAD 2016 Rural Development Report.

Tegegne, A. D., \& Penker, M. 2016. Determinants of Rural Out-Migration in Ethiopia: Who Stays and Who Goes?. Demographic Research, 35, 1011.

TP4D. 2018. Fostering territorial perspective for development. Towards a wider alliance. 8p.

UNDESA. 2010. World Population Prospects: The 2010 Revision. New York: United Nations.

UNDESA. 2015a. Trends in International Migrant Stock: Migrants by Destination and Origin. New York: United Nations.

UNDESA. 2015b. Trends in International Migrant Stock: Migrants by Age and Sex. New York: United Nations.

UNDESA. 2017. World Population Prospects: The 2017 Revision. New York: United Nations.

UNDESA. 2018. World Urbanization Prospects: The 2018 Revision. New York: United Nations.

UNDESA. 2019. Trends in International Migrant Stock: Migrants by Destination and Origin. New York: United Nations.

UNDP. 2009. Human development report 2009. Overcoming barriers: Human mobility and development, New York: UNDP, 229 p.

UNHCR. 1998. Guiding Principles on Internal Displacement. Annexed to United Nations Commission on Human Rights, Report of the Representative of the Secretary-General, Mr Francis M. Deng, Submitted Pursuant to Commission Resolution 1997/39. UN Doc E/CN.4/1998/53/Add.2, 6.

Van Hear, N., O. Bakewell, and Long, K. 2017. Push-pull Plus: Reconsidering the Drivers of Migration. Journal of Ethnic and Migration Studies. 44(6): 927-944, DOI: 10.1080/1369183X.2017.1384135

Valsson, T., Ulfarsson, G.F. 2012. Mega-patterns of global settlement: Typology and drivers in a warming world. Futures, 44, pp. 91-104.

Vyas, S., \& Kumaranayake, L. 2006. Constructing socio-economic status indices: how to use principal components analysis. Health policy and planning, 21(6): 459-468.

Wallerstein, I. 1974. The Modern World System I, Capitalist Agriculture and the Origins of the European World Economy in the Sixteenth Century. New York, Academic Press, Cambridge policy.

Willekens, F. 2011. Migration: A perspective from complexity science. New approaches for researching the determinants of migration processes: ESF strategic workshop on migration research. University of Oxford: IMI and European Science Foundation, 29-30 September 2011. 1-7.

World Bank. 2009. Shaping the future: a long-term perspective of people and job mobility for the Middle East and North Africa. Washington, DC: World Bank.

Xiang, B. and Lindquist, J. 2014. Migration Infrastructure. International Migration Review, 48:S122-S148 


\section{Annexes}

Annex 1: Preliminary assessment of available relevant datasets on migration

\begin{tabular}{|c|c|c|c|c|c|c|c|}
\hline \multirow[b]{2}{*}{$\begin{array}{l}\text { Survey/ source } \\
\text { and type of } \\
\text { access }\end{array}$} & \multirow[b]{2}{*}{ Country (Years) } & \multicolumn{5}{|c|}{$\begin{array}{l}\text { Type of migration information included in the survey } \\
\text { format }\end{array}$} & \multirow[t]{2}{*}{ Notes } \\
\hline & & $\begin{array}{l}\text { Rural } \\
\text {-urban: } \\
\text { location of } \\
\text { household } \\
(y / n)\end{array}$ & $\begin{array}{l}\text { Who has } \\
\text { migrated } \\
(y / n)\end{array}$ & $\begin{array}{l}\text { Migration : } \\
\text { (0) no } \\
\text { (1) national } \\
\text { (2) } \\
\text { international } \\
\text { (3) both }\end{array}$ & $\begin{array}{c}\text { Reasons for } \\
\text { migrating } \\
(y / n)\end{array}$ & $\begin{array}{c}\text { Activity at } \\
\text { destination } \\
(y / n)\end{array}$ & \\
\hline \multirow[t]{4}{*}{$\begin{array}{l}\text { LSMS-ISA } \\
\text { (Living } \\
\text { standards } \\
\text { measurement } \\
\text { surveys- } \\
\text { Int Surv } \\
\text { Agriculture) } \\
8 \text { countries } \\
\text { World Bank * }\end{array}$} & $\begin{array}{l}\text { 1. Burkina } \\
\text { Enquête multi- } \\
\text { sectorielle } \\
\text { continue } 2014\end{array}$ & $y$ & $y$ & 3 & $y$ & $y$ & $\begin{array}{l}\text { Information } \\
\text { on } \\
\text { outmigration } \\
\text { is available } \\
\text { for Ethiopia, } \\
\text { Malawi, Mali, } \\
\text { Niger and } \\
\text { Nigeria. }\end{array}$ \\
\hline & $\begin{array}{l}\text { 2.Ethiopia } \\
\text { Ethiopia Rural } \\
\text { Socioeconomic } \\
\text { Survey 2011-2012 } \\
\text { Socioeconomic } \\
\text { Survey } \\
2013-2014 \\
\text { Socioeconomic } \\
\text { Survey } \\
\text { 2015-2016 }\end{array}$ & $y$ & $y$ & 3 & $\mathrm{y}$ & $y$ & \\
\hline & $\begin{array}{l}\text { 3.Malawi } \\
\text { Third Integrated } \\
\text { Household Survey } \\
\text { 2010-2011 } \\
\text { Integrated } \\
\text { Household Panel } \\
\text { Survey } 2013\end{array}$ & $\begin{array}{c}Y \\
\text { but not } \\
\text { explicit }\end{array}$ & $\begin{array}{l}\text { Y Includes } \\
\text { data on } \\
\text { migrant } \\
\text { children or } \\
\text { spouse of } \\
\text { the head } \\
\text { of the } \\
\text { household }\end{array}$ & 3 & $y$ & $y$ & $\begin{array}{l}\text { For Malawi } \\
\text { and } \\
\text { Tanzania, } \\
\text { there is } \\
\text { no direct } \\
\text { indications } \\
\text { regarding } \\
\text { rural/ } \\
\text { urban, but } \\
\text { localisation } \\
\text { code should } \\
\text { allow to sort } \\
\text { it. }\end{array}$ \\
\hline & $\begin{array}{l}\text { 4. Mali } \\
\text { Enquête Agricole } \\
\text { de Conjoncture } \\
\text { Intégrée aux } \\
\text { conditions de } \\
\text { vie des ménages } \\
2014\end{array}$ & $y$ & $y$ & 3 & $y$ & $y$ & $\begin{array}{l}\text { Missing } \\
\text { values }\end{array}$ \\
\hline
\end{tabular}




\begin{tabular}{|c|c|c|c|c|c|c|c|}
\hline \multirow[b]{2}{*}{$\begin{array}{l}\text { Survey/ source } \\
\text { and type of } \\
\text { access }\end{array}$} & \multirow[b]{2}{*}{ Country (Years) } & \multicolumn{5}{|c|}{ Type of migration information included in the survey format } & \multirow[t]{2}{*}{ Notes } \\
\hline & & $\begin{array}{l}\text { Rural } \\
\text {-urban: } \\
\text { location of } \\
\text { household } \\
(\mathrm{y} / \mathrm{n})\end{array}$ & $\begin{array}{l}\text { Who has } \\
\text { migrated }(y / n)\end{array}$ & $\begin{array}{l}\text { Migration : } \\
(0) \text { no } \\
(1) \text { national } \\
(2) \\
\text { international } \\
\text { (3) both }\end{array}$ & $\begin{array}{l}\text { Reasons } \\
\text { for } \\
\text { migrating } \\
\quad(y / n)\end{array}$ & $\begin{array}{c}\text { Activity at } \\
\text { destination } \\
(y / n)\end{array}$ & \\
\hline & $\begin{array}{l}\text { 5. Niger } \\
\text { Enquête Nationale } \\
\text { sur les Conditions de } \\
\text { Vie des Ménages et } \\
\text { l'Agriculture } 2011 \\
\text { Enquête Nationale } \\
\text { sur les Conditions } \\
\text { de Vie des Ménages } \\
\text { et l'Agriculture2014 }\end{array}$ & y & y & 3 & y & $\mathrm{n}$ & $\begin{array}{l}\text { Accoding } \\
\text { to available } \\
\text { data, surveys } \\
\text { in Mali and } \\
\text { Niger have } \\
\text { not collected } \\
\text { done on out- } \\
\text { migration }\end{array}$ \\
\hline & $\begin{array}{l}\text { 6. Nigeria } \\
\text { General Household } \\
\text { Survey 2010-2011 } \\
\text { General Household } \\
\text { Survey 2012-2013 } \\
\text { General Household } \\
\text { Survey 2015-2016 }\end{array}$ & $\mathrm{y}$ & $\mathrm{y}$ & 3 & y & $\mathrm{y}$ & \\
\hline & $\begin{array}{l}\text { 7. Tanzania } \\
\text { National Panel } \\
\text { Survey 2008-2009 } \\
\text { National Panel } \\
\text { Survey 2010-2011 } \\
\text { National Panel } \\
\text { Survey 2012-2013 }\end{array}$ & $\begin{array}{c}\text { y } \\
\text { but not } \\
\text { explicitly }\end{array}$ & $\begin{array}{c}y \\
\text { (in-migration } \\
\text { only) }\end{array}$ & $\begin{array}{c}3 \\
\text { (in-migration } \\
\text { only) }\end{array}$ & y & $\begin{array}{c}\text { y } \\
\text { (in-migration } \\
\text { only) }\end{array}$ & $\begin{array}{l}\text { For Tanzania } \\
\text { and Uganda, } \\
\text { migration } \\
\text { information } \\
\text { is available } \\
\text { only about } \\
\text { people } \\
\text { who have } \\
\text { returned } \\
\text { to the } \\
\text { household. }\end{array}$ \\
\hline & $\begin{array}{l}\text { 8. Uganda } \\
\text { National Panel } \\
\text { Survey 2009-2010 } \\
\text { National Panel } \\
\text { Survey 2010-2011 } \\
\text { National Panel } \\
\text { Survey 2011-2012 } \\
\text { National Panel } \\
\text { Survey 2013-2014 }\end{array}$ & y & $\begin{array}{c}\text { y } \\
\text { (in-migration } \\
\text { only) }\end{array}$ & $\begin{array}{c}3 \\
\text { (in-migration } \\
\text { only) }\end{array}$ & y & $\begin{array}{c}y \\
\text { (in-migration } \\
\text { only) }\end{array}$ & $\begin{array}{l}\text { Concerns } \\
\text { with quality } \\
\text { of data and } \\
\text { missing } \\
\text { values. }\end{array}$ \\
\hline $\begin{array}{l}\text { LSMS (Living } \\
\text { standards } \\
\text { measurement } \\
\text { surveys) } \\
\text { World Bank * }\end{array}$ & $\begin{array}{l}\text { Ghana } \\
\text { Living Standard } \\
\text { Survey (2013) } \\
\text { Not included in } \\
\text { the LSMS-ISA } \\
\text { project but detailed } \\
\text { Information on out- } \\
\text { migration. }\end{array}$ & y & y & 3 & $\mathrm{y}$ & y & \\
\hline
\end{tabular}




\begin{tabular}{|c|c|c|c|c|c|c|c|}
\hline \multirow[b]{2}{*}{$\begin{array}{l}\text { Survey/ source } \\
\text { and type of } \\
\text { access }\end{array}$} & \multirow[b]{2}{*}{ Country (Years) } & \multicolumn{5}{|c|}{$\begin{array}{l}\text { Type of migration information included in the survey } \\
\text { format }\end{array}$} & \multirow[t]{2}{*}{ Notes } \\
\hline & & $\begin{array}{l}\text { Rural } \\
\text {-urban: } \\
\text { location of } \\
\text { household } \\
(y / n)\end{array}$ & $\begin{array}{l}\text { Who has } \\
\text { migrated } \\
(y / n)\end{array}$ & $\begin{array}{l}\text { Migration : } \\
(0) \text { no } \\
\text { (1) national } \\
(2) \\
\text { international } \\
\text { (3) both }\end{array}$ & $\begin{array}{l}\text { Reasons } \\
\text { for } \\
\text { migrating } \\
\quad(y / n)\end{array}$ & $\begin{array}{c}\text { Activity at } \\
\text { destination } \\
(y / n)\end{array}$ & \\
\hline \multirow[t]{7}{*}{$\begin{array}{l}\text { MRHS } \\
\text { (Migration and } \\
\text { Remittances } \\
\text { Household } \\
\text { Survey), World } \\
\text { bank } \\
\text { ( } 7 \text { countries) }\end{array}$} & $\begin{array}{l}\text { 1. Nigeria: } \\
\text { Migration } \\
\text { Household } \\
\text { Survey, } 2009\end{array}$ & $y$ & $\begin{array}{c}\text { y } \\
\text { (databases } \\
\text { sparsely } \\
\text { populated/ } \\
\text { no } \\
\text { response) }\end{array}$ & 3 & $y$ & $\begin{array}{c}\mathrm{Y} \\
\text { (databases } \\
\text { sparsely } \\
\text { populated/ } \\
\text { no } \\
\text { response) }\end{array}$ & \\
\hline & $\begin{array}{l}\text { 2. Senegal: } \\
\text { Migration and } \\
\text { Remittances } \\
\text { Household } \\
\text { Survey, } 2009\end{array}$ & $y$ & $y$ & 3 & y & & \\
\hline & $\begin{array}{l}\text { 3. Uganda: } \\
\text { Migration } \\
\text { Household } \\
\text { Survey, } 2010 \\
\text { Future of African } \\
\text { Remittances: } \\
\text { National } \\
\text { Surveys, } 2010\end{array}$ & $y$ & $y$ & 3 & & & \\
\hline & $\begin{array}{l}\text { 4. Burkina Faso: } \\
\text { Enquête Ménage } \\
\text { sur la Migration } \\
\text { et les Transferts } \\
\text { de Fonds, } 2010\end{array}$ & $y$ & & & & & \\
\hline & $\begin{array}{l}\text { 5. Ethiopia: } \\
\text { Future of African } \\
\text { Remittances: } \\
\text { National Survey, } \\
2010\end{array}$ & $y$ & & & & & $\begin{array}{l}\text { Different } \\
\text { questionnaire }\end{array}$ \\
\hline & $\begin{array}{l}\text { 6. Kenya: } \\
\text { Migration } \\
\text { Household } \\
\text { Survey, 2009; } \\
\text { Future of African } \\
\text { Remittances: } \\
\text { National Survey, } \\
2010 \\
\end{array}$ & $y$ & & & & & \\
\hline & $\begin{array}{l}\text { 7. South Africa: } \\
\text { Migration and } \\
\text { Household } \\
\text { Survey, } 2009\end{array}$ & $y$ & & & & & $\begin{array}{l}\text { Not nationally } \\
\text { representative }\end{array}$ \\
\hline
\end{tabular}




\begin{tabular}{|c|c|c|c|c|c|c|c|}
\hline \multirow[b]{2}{*}{$\begin{array}{l}\text { Survey/ } \\
\text { source and } \\
\text { type of access }\end{array}$} & \multirow[b]{2}{*}{ Country (Years) } & \multicolumn{5}{|c|}{$\begin{array}{l}\text { Type of migration information included in the survey } \\
\text { format }\end{array}$} & \multirow[t]{2}{*}{ Notes } \\
\hline & & $\begin{array}{l}\text { Rural } \\
\text {-urban: } \\
\text { location of } \\
\text { household } \\
(\mathrm{y} / \mathrm{n})\end{array}$ & $\begin{array}{l}\text { Who has } \\
\text { migrated }(y / n)\end{array}$ & $\begin{array}{l}\text { Migration : } \\
(0) \text { no } \\
(1) \text { national } \\
(2) \\
\text { international } \\
\text { (3) both } \\
\end{array}$ & $\begin{array}{l}\text { Reasons } \\
\text { for } \\
\text { migrating } \\
(y / n)\end{array}$ & $\begin{array}{c}\text { Activity at } \\
\text { destination } \\
(y / n)\end{array}$ & \\
\hline $\begin{array}{l}\text { LMM (Labour } \\
\text { Migration } \\
\text { Module) / } \\
\text { ILOSTAT ** }\end{array}$ & \multicolumn{7}{|c|}{$\begin{array}{l}\text { ILO's Labour Migration Module consists of a series of migration-related questions added to existing household } \\
\text { and labour force surveys. The module is a tool for gathering data on labour migration; the socio-demographic } \\
\text { composition of labour migrants, including their educational attainment and areas of training before departure; as } \\
\text { well as their economic activities, working conditions, and the frequency and duration of their travel. While module } \\
\text { questions cover a wide range of migration topics, special attention is given to the employment situation of current } \\
\text { and former migrants and to international remittances. Country priorities determine the choice of questions. } \\
\text { For Africa, sections of the module were first tested in Egypt (2006/2007) and Zimbabwe (2011-2012) }\end{array}$} \\
\hline $\begin{array}{l}\text { ILO / Labour } \\
\text { force surveys } \\
\text { (LFS) } \\
30 \text { SSA } \\
\text { countries } \\
\text { for different } \\
\text { years } \\
\text { http://www. } \\
\text { ilo.org/dyn/ } \\
\text { Ifsurvey/ } \\
\text { Ifsurvey.home }\end{array}$ & \multicolumn{7}{|c|}{$\begin{array}{l}\text { Existing surveys realized between } 2008 \text { and 2014. Initial exploration for } 2 \text { countries reveal rural-urban } \\
\text { disaggregated data exist on who has migrated, type and reason of migration as well as activity of migrant at } \\
\text { destination } \\
\text { List of countries: Burkina Faso - Cameroon - Congo - Democratic Republic of Congo - Cote d'Ivoire - Egypt - } \\
\text { Labour Force Survey (years not specified), Ethiopia - National Labour Force Survey } 2013 \\
\text { Gabon - Gambia - The Gambia Labour Force Survey, April 2012; Ghana - Labour Force Survey 2015; Kenya - } \\
\text { Economic Survey 1960-2016 ; Lesotho - Labour Force Survey } 2008 \\
\text { Liberia - Labour Force Survey } 2010 \text {; Madagascar - Malawi - Malawi Labour Force Surver } 2013 \text {; Mali; } \\
\text { Mozambique; Namibia - Labour Force Survey } 2014 \text {; Nigeria - Labour Force Survey ; Rwanda - Labour Force } \\
\text { Survey 2016; Senegal - Sierra Leone - Labour Force Survey 2014 ; South Africa - Quarterly Labour Force Survey; } \\
\text { Sudan - Labour Force Survey 2011; Swaziland - Labour Force Survey ;Tanzania - 2005/06 - Integrated Labour } \\
\text { Force Survey (ILFS)/ 2014 Integrated Labour Force Survey (ILFS); Uganda - The National Labour Force and Child } \\
\text { Activities Survey 2011/12; Zambia - Labour Force Survey 2014; Zimbabwe - Labour Force Survey } 2014 .\end{array}$} \\
\hline $\begin{array}{l}\text { OECD } \\
\text { Database on } \\
\text { Immigrants } \\
\text { in OECD and } \\
\text { non OECD } \\
\text { countries } \\
\text { (DIOC-E) } \\
\text { Includes } \\
17 \text { African } \\
\text { countries }\end{array}$ & $\begin{array}{l}\text { An extension of DIOC } \\
\text { to a number of non- } \\
\text { OECD countries for } \\
\text { the year 2000/01 and } \\
2010 / 11 . \\
\text { Provides } \\
\text { comprehensive } \\
\text { and comparative } \\
\text { information on } \\
\text { a broad range of } \\
\text { demographic and } \\
\text { labour market } \\
\text { characteristics of } \\
\text { immigrants living in } \\
\text { OECD and part of non } \\
\text { OECD countries. }\end{array}$ & $n$ & $y$ & 2 & $n$ & $y$ & $\begin{array}{l}\text { Interesting } \\
\text { source } \\
\text { especially } \\
\text { for data on } \\
\text { migration and } \\
\text { education. } \\
\text { There is no } \\
\text { disaggregation } \\
\text { for rural and } \\
\text { urban }\end{array}$ \\
\hline
\end{tabular}




\begin{tabular}{|c|c|c|c|c|c|c|c|}
\hline \multirow[b]{2}{*}{$\begin{array}{l}\text { Survey/ source } \\
\text { and type of } \\
\text { access }\end{array}$} & \multirow[b]{2}{*}{ Country (Years) } & \multicolumn{5}{|c|}{$\begin{array}{c}\text { Type of migration information included in the survey } \\
\text { format }\end{array}$} & \multirow[t]{2}{*}{ Notes } \\
\hline & & $\begin{array}{l}\text { Rural } \\
\text {-urban: } \\
\text { location of } \\
\text { household } \\
(y / n)\end{array}$ & & $\begin{array}{l}\text { Migration : } \\
\text { (0) no } \\
\text { (1) national } \\
\text { (2) } \\
\text { international } \\
\text { (3) both }\end{array}$ & $\begin{array}{l}\text { Reasons } \\
\text { for } \\
\text { migrating } \\
\quad(y / n)\end{array}$ & $\begin{array}{c}\text { Activity at } \\
\text { destination } \\
(y / n)\end{array}$ & \\
\hline $\begin{array}{l}\text { ILO "School to } \\
\text { work transition } \\
\text { survey" *** } \\
\text { (8 African } \\
\text { countries) }\end{array}$ & \multicolumn{7}{|c|}{$\begin{array}{l}\text { Include data on: Employed and unemployed youth that would consider moving (internal or international) by area } \\
\text { of residence (rural-urban) and by sex; Employed youth who would consider moving by level of job satisfaction and } \\
\text { area of residence (rural-urban). } \\
\text { Countries: Benin, Liberia, Madagascar, Malawi, Zambia, Tanzania, Uganda, Democratic Republic of Congo Years: } \\
\text { 2012-2013/2014-2015 }\end{array}$} \\
\hline $\begin{array}{l}\text { IMI/DEMIG } \\
\text { project } \\
\text { (Determinants } \\
\text { of International } \\
\text { Migration) } \\
30 \text { African }\end{array}$ & \multicolumn{7}{|c|}{$\begin{array}{l}\text { DEMIG Policy: tracks more than } 6,500 \text { migration policy changes enacted by } 45 \text { countries around the world mostly } \\
\text { in the } 1945-2013 \text { period. The policy measures are coded according to the policy area and migrant group targeted, } \\
\text { as well as the change in restrictiveness they introduce in the existing legal system. The dataset allows for both } \\
\text { quantitative and qualitative research on the long-term evolution and effectiveness of migration policies. https:// } \\
\text { www.imi.ox.ac.uk/data/demig-data/demig-policy-1 } \\
\text { Morroco (since 1945); South Africa (Since 1900) }\end{array}$} \\
\hline & \multicolumn{6}{|c|}{$\begin{array}{l}\text { DEMIG TOTAL reports immigration, emigration and net migration flows for up to } 161 \text { countries } \\
\text { covering various periods of time from the early } 1800 \text { s to } 2011 \text {, disaggregating total flows of } \\
\text { citizens and foreigners whenever possible. The dataset allows for quantitative analysis of the } \\
\text { long-term evolution of international migration. https://www.imi.ox.ac.uk/data/demig-data/ } \\
\text { demig-total-data }\end{array}$} & $\begin{array}{l}\text { no } \\
\text { disaggregation } \\
\text { for rural and } \\
\text { urban }\end{array}$ \\
\hline $\begin{array}{l}\text { Population } \\
\text { Census } \\
\text { Through Ipums } \\
\text { initiative }\end{array}$ & \multicolumn{7}{|c|}{$\begin{array}{l}\text { The Integrated Public Use Microdata Series (IPUMS) try to harmonise and provide data on population. They are } \\
\text { based on } 10 \text { percent random samples of national population censes conducted between } 1990 \text { and } 2010 \text {. These } \\
\text { nationally representative surveys have multiple waves for several African countries and include migration and } \\
\text { labour market information } \\
\text { Useful websites to access Census data: } \\
\text { https://international.ipums.org/international/ } \\
\text { https://www.geog.leeds.ac.uk/research/csap/projects/image/ }\end{array}$} \\
\hline
\end{tabular}

*Regarding LSMS-ISA surveys: Information provided in the table concerns the latest survey.

The surveys include information on remittances, which indirectly can provide some complementary information about outmigration. This information is usually located in a financement/funding module.

For remittances, additional data source: https://www.worldbank.org/en/topic/migrationremittancesdiasporaissues/ brief/migration-remittances-data

**The ILO database on labour statistics (ILOSTAT) provides statistics on international labour migration, which cover indicators on international migrant stock, international migrant flow and nationals abroad for selected ASEAN and Arab countries from 2001 to 2013. The data are in the form of cross-tabulations. Available at: http://www.ilo.org/ global/topics/labour-migration/policy-areas/statistics/lang--en/index.htm

***Scool to Work Surveys : http://www.ilo.org/employment/areas/WCMS_234860/lang--en/index.htm.

These household surveys of young people aged 15-29 years were conducted in 28 countries, with rural/urban distinctions available in 25 countries, between 2012 and 2013. The datasets (both in SPSS and STATA format) contain all individual variables plus three derived variables, "employment", "unemployment" and "school enrolment". For more information on derived variables, see methodology. To access data files: w4y@ilo.org 
Annex 2: Missing values for selected variables in 6 countries

\begin{tabular}{|c|c|c|c|c|c|c|c|c|c|c|c|c|}
\hline \multicolumn{13}{|c|}{ Percentages of missing data in the selected variables } \\
\hline Country & \multicolumn{2}{|c|}{ Ethiopia } & \multicolumn{2}{|c|}{ Ghana } & \multicolumn{2}{|c|}{ Malawi } & \multicolumn{2}{|c|}{ Mali } & \multicolumn{2}{|c|}{ Nigeria } & \multicolumn{2}{|c|}{ Uganda } \\
\hline Variable & Sample & ssing $\%$ & Sample & ssing $\%$ & Sample & ssing $\%$ & Sample & $\operatorname{sing} \%$ & Sample & issing \% & Sample & $\operatorname{ssing} \%$ \\
\hline Brick walls & 3,272 & 0 & 9,327 & 0 & 2,954 & 0 & 2,399 & 0 & NA & NA & 2,302 & 0 \\
\hline Own home & 3,272 & 0 & 9,327 & 0 & 2,954 & 0 & 2,399 & 0 & NA & NA & 2,302 & 0 \\
\hline $\begin{array}{l}\text { Non-dirt } \\
\text { floor }\end{array}$ & 3,272 & 0 & 9,327 & 0 & 2,954 & 0 & 2,399 & 0 & NA & NA & 2,302 & 0 \\
\hline Solid roof & 3,272 & 0 & 9,327 & 0 & 2,954 & 0 & 2,399 & 0 & NA & NA & 2,302 & 0 \\
\hline electricity & 3,272 & 0 & 9,327 & 0 & 2,954 & 0 & 2,399 & 0 & 3,299 & 0,45 & 2,302 & 0,09 \\
\hline Safe water & 3,272 & 0 & 9,327 & 0 & 2,954 & 0 & 2,399 & 0 & 3,299 & 0,45 & 2,302 & 4,95 \\
\hline Toilet & 3,272 & 0 & 9,327 & 0 & 2,954 & 0 & 2,399 & 0 & 3,299 & 0,45 & 2,302 & 0 \\
\hline irrigation & 3,272 & 13,78 & 9,327 & 18,26 & 2,954 & 16,32 & 2,399 & 11,95 & 3,299 & 23,86 & 2,302 & 21,03 \\
\hline $\begin{array}{l}\text { Large } \\
\text { ruminant }\end{array}$ & 3,272 & 1,8 & 9,327 & 35,71 & 2,954 & 42,15 & 2,399 & 22,09 & 3,299 & 16,55 & 2,302 & 73,28 \\
\hline Rooms & 3,272 & 0 & 9,327 & 0 & 2,954 & 0 & 2,399 & 0 & NA & NA & 2,302 & 0 \\
\hline Cell phone & 3,272 & 0 & 9,327 & 10,61 & 2,954 & 0 & 2,399 & 0 & 3,299 & 0,45 & 2,302 & 0 \\
\hline $\begin{array}{l}\text { Highest } \\
\text { education }\end{array}$ & 3,272 & 17,27 & 9,327 & 10,64 & 2,954 & 3,93 & 2,399 & 66,19 & 3,299 & 1,27 & 2,302 & 9,95 \\
\hline Hh size & 3,272 & 0 & 9,327 & 0 & 2,954 & 0 & 2,399 & 0 & 3,299 & 0 & 2,302 & 0 \\
\hline farm area & 3,272 & 2,29 & 9,327 & 18,27 & 2,954 & 14,15 & 2,399 & 10,25 & 3,299 & 20,7 & 2,302 & 8,91 \\
\hline Shocks & 3,272 & 0 & NA & NA & 2,954 & 0 & 2,399 & 0 & 3,299 & 0,45 & 2,302 & 0,26 \\
\hline Market & 3,272 & 0 & NA & NA & 2,954 & 0 & 2,399 & 0 & 3,299 & 0,45 & 2,302 & 0,26 \\
\hline
\end{tabular}




\begin{tabular}{|c|c|c|c|c|c|c|}
\hline \multirow[t]{2}{*}{ Variable } & \multicolumn{6}{|c|}{ Availability/Number of Missing Values } \\
\hline & Ghana & Ethiopia & Malawi & Mali & Nigeria & Uganda \\
\hline Female headed household & 0 & n.a. & n.a. & 0 & n.a. & n.a. \\
\hline Age of household head & 0 & n.a. & n.a. & 0 & n.a. & n.a. \\
\hline Household size & 0 & 0 & 0 & 0 & 0 & 0 \\
\hline Female share of household labor & 0 & 0 & 0 & 0 & $\begin{array}{c}39 \\
(1,2 \%)\end{array}$ & 0 \\
\hline $\begin{array}{l}\text { Highest years of education in } \\
\text { household }\end{array}$ & $\begin{array}{c}992 \\
(10,6 \%)\end{array}$ & 565 & 116 & 1,558 & 42 & 229 \\
\hline Household experience of shocks & n.a. & 0 & 0 & 0 & 15 & $\begin{array}{c}6 \\
(0.03 \%)\end{array}$ \\
\hline Total land owned & $\begin{array}{l}3,962 \\
(42.5 \%)\end{array}$ & 0 & 0 & $\begin{array}{c}453 \\
(18.0 \%)\end{array}$ & $\begin{array}{c}668 \\
(20.2 \%)\end{array}$ & 0 \\
\hline Total livestock owned & 0 & $\begin{array}{c}356 \\
(10,9 \%)\end{array}$ & 0 & 0 & 0 & 0 \\
\hline Household owns operating phone & $\begin{array}{c}990 \\
(10,6 \%)\end{array}$ & 0 & 0 & 0 & $\begin{array}{c}15 \\
(0.5 \%)\end{array}$ & 0 \\
\hline Household has solid roof & 0 & 0 & 0 & 0 & NA & 0 \\
\hline Male share of household labor & 0 & 0 & 0 & 0 & $\begin{array}{c}39 \\
(10,6 \%)\end{array}$ & 0 \\
\hline Access to credit & 0 & 0 & 0 & 0 & 0 & NA \\
\hline Farm area operated (in hectares) & $\begin{array}{c}1,704 \\
(18.3 \%)\end{array}$ & $\begin{array}{c}75 \\
(2.3 \%)\end{array}$ & $\begin{array}{c}418 \\
(14.2 \%)\end{array}$ & $\begin{array}{c}246 \\
(10.3 \%)\end{array}$ & $\begin{array}{c}683 \\
(20.7 \%)\end{array}$ & $\begin{array}{c}205 \\
(8.9 \%)\end{array}$ \\
\hline Access to electricity & 0 & 0 & 0 & 0 & $\begin{array}{c}15 \\
(0.5 \%)\end{array}$ & 0 \\
\hline Access to safe water & 0 & 0 & 0 & 0 & $\begin{array}{c}15 \\
(0.5 \%)\end{array}$ & $\begin{array}{c}114 \\
(5.0 \%)\end{array}$ \\
\hline Access to toilet facility & 0 & 0 & 0 & 0 & $\begin{array}{c}15 \\
(0.5 \%)\end{array}$ & $\begin{array}{c}2 \\
(0.1 \%)\end{array}$ \\
\hline Irrigation use & $\begin{array}{c}1703 \\
(18.3 \%)\end{array}$ & $\begin{array}{c}451 \\
(13.9 \%)\end{array}$ & $\begin{array}{c}482 \\
(16.3 \%)\end{array}$ & $\begin{array}{c}265 \\
(11.0 \%)\end{array}$ & $\begin{array}{c}787 \\
(23.9 \%)\end{array}$ & $\begin{array}{c}484 \\
(21.0 \%)\end{array}$ \\
\hline Access to extension services & NA & $\begin{array}{c}59 \\
(1.8 \%)\end{array}$ & $\begin{array}{c}188 \\
(6.4 \%)\end{array}$ & $\begin{array}{c}240 \\
(10.0 \%)\end{array}$ & $\begin{array}{c}531 \\
(16.1 \%)\end{array}$ & $\begin{array}{c}189 \\
(8.2 \%)\end{array}$ \\
\hline Coverage of social assistance & 0 & 0 & 0 & 0 & 0 & NA \\
\hline Main dwelling walls material - brick & 0 & 0 & 0 & 0 & NA & 0 \\
\hline $\begin{array}{l}\text { Dwelling has non-dirt/non-mud } \\
\text { floor }\end{array}$ & 0 & 0 & 0 & 0 & NA & 0 \\
\hline Household owns dwelling & 0 & 0 & 0 & 0 & NA & 0 \\
\hline Raising livestock no land & NA & 506 & 1243 & NA & 668 & 190 \\
\hline Household owning equine & 3331 & 59 & 1243 & 530 & 546 & 1687 \\
\hline Household owning poultry & 3331 & 59 & 1243 & 530 & 546 & 1160 \\
\hline $\begin{array}{l}\text { Household owning small } \\
\text { ruminants }\end{array}$ & 3331 & 59 & 1243 & 530 & 546 & 1175 \\
\hline $\begin{array}{l}\text { Household owning large } \\
\text { ruminants }\end{array}$ & 3331 & 59 & 1243 & 530 & 546 & 1687 \\
\hline $\begin{array}{l}\text { Number of rooms } \mathrm{HH} \text { members } \\
\text { occupy }\end{array}$ & 0 & 0 & 0 & 0 & NA & 0 \\
\hline
\end{tabular}


Annex 3: Definition and measurement of variables for the binary logistic model

\begin{tabular}{|c|c|c|c|}
\hline $\begin{array}{l}\text { Variable } \\
\text { type }\end{array}$ & Variable & Definition and Description & $\begin{array}{c}\text { Household } \\
\text { characteristics domain }\end{array}$ \\
\hline Dependent & $\begin{array}{l}\text { Rural migrant } \\
\text { household }\end{array}$ & $\begin{array}{l}\text { Dummy variable, where migrant-household }=1 \text { and } \\
\text { non-migrant household }=0\end{array}$ & \\
\hline \multirow[t]{10}{*}{ Independent } & Household size & $\begin{array}{l}\text { Discrete variable measured as the number of } \\
\text { household members in the household at the time } \\
\text { of the survey. }\end{array}$ & \multirow{3}{*}{$\begin{array}{c}\text { Demographic \& Human } \\
\text { capital }\end{array}$} \\
\hline & $\begin{array}{l}\text { Female share of } \\
\text { household labour }^{\mathrm{b}}\end{array}$ & $\begin{array}{l}\text { Continuous variable measured as the proportion } \\
\text { of female on the total number of household } \\
\text { members at the time survey. }\end{array}$ & \\
\hline & $\begin{array}{l}\text { Highest years } \\
\text { of education in } \\
\text { household }\end{array}$ & $\begin{array}{l}\text { Discrete variable measured as the highest number } \\
\text { of schooling years of a household members at the } \\
\text { time of the survey. }\end{array}$ & \\
\hline & $\begin{array}{l}\text { Household } \\
\text { experience of } \\
\text { shocks (weather, } \\
\text { market and } \\
\text { decease) }\end{array}$ & $\begin{array}{l}\text { Dummy variable, where a household who } \\
\text { experiences either weather, market or disease } \\
\text { shocks is measured as } 1 \text { and } 0 \text { when the } \\
\text { household does not experience any of these } \\
\text { shocks at the time of the survey. }\end{array}$ & Shock \& Extreme events \\
\hline & $\begin{array}{l}\text { Total farmland } \\
\text { owned }\end{array}$ & $\begin{array}{l}\text { Continuous variable measured as the number of } \\
\text { hectares of land that a household owns at the time } \\
\text { of the survey. }\end{array}$ & \multirow{6}{*}{ Economic well-being } \\
\hline & $\begin{array}{l}\text { Total livestock } \\
\text { owned }\end{array}$ & $\begin{array}{l}\text { Discrete variable measured as the number of } \\
\text { livestock of all types that a household owns at the } \\
\text { time of the survey. }\end{array}$ & \\
\hline & $\begin{array}{l}\text { Household owns } \\
\text { operating phone }\end{array}$ & $\begin{array}{l}\text { Dummy variable, where a household with at } \\
\text { least a member owning an operating cell phone } \\
\text { is measured as } 1 \text { and } 0 \text { for households with no } \\
\text { member owning an operating cell phone at the } \\
\text { time of the survey. }\end{array}$ & \\
\hline & $\begin{array}{l}\text { Household has solid } \\
\text { roof }\end{array}$ & $\begin{array}{l}\text { Dummy variable, where a household with a decent } \\
\text { roofing of their dwelling is measured as } 1 \text { and } 0 \text { for } \\
\text { households with no decent or solid roofing of their } \\
\text { dwelling unit at the time of the survey. }\end{array}$ & \\
\hline & Social insurance & $\begin{array}{l}\text { Continuous variable measured as the value of } \\
\text { social insurance benefit that the household } \\
\text { received. }\end{array}$ & \\
\hline & Electricity & $\begin{array}{l}\text { Dummy variable, where a household with a } \\
\text { access to electricity is measured as } 1 \text { and } 0 \text { for } \\
\text { households with no access to electricity to their } \\
\text { dwelling unit at the time of the survey. }\end{array}$ & \\
\hline
\end{tabular}

(a) RuLIS definition of migrants (variable at the household level): Dummy variable indicating whether at least one member of the household qualified as a migrant, either international or internal, during the 12 months prior to the interview. The definition of migrant is survey-specific.

(b) Existing literature point to the fact that migration is largely dominated by men, thus increase in female share of household labour might be indicative of more migration of men. In addition, for households with majority of their members being female, the pressure for a member to migrate (be it male or female) is high. As the regressions results showed, this was found to be a significant predictor of migration in Ethiopia and may be instructive for future research. 
Annex 4: Synthetic tables of the 37 future studies

Table 1. Characteristics of eight futures studies focusing on forecast

\begin{tabular}{|c|c|c|c|c|c|}
\hline Reference & Dimension & Drivers & Scale & Pattern & Relevance \\
\hline $\begin{array}{l}\text { Shaping the } \\
\text { Future: A Long- } \\
\text { Term Perspective } \\
\text { of People and Job } \\
\text { Mobility for the } \\
\text { Middle East and } \\
\text { North Africa (WB, } \\
\text { 2009) }\end{array}$ & $\begin{array}{l}\text { Social } \\
\text { Economic }\end{array}$ & $\begin{array}{l}\text { Demographic trends in } \\
\text { Europe and MENA Labor } \\
\text { demand in Europe; } \\
\text { Labor supply in MENA. }\end{array}$ & $\begin{array}{l}\text { Cross- } \\
\text { regional } \\
(\text { EU-MENA) }\end{array}$ & $\begin{array}{l}\text { Different scenarios based on } \\
\text { education profiles and labor } \\
\text { force participation rates are } \\
\text { used to assess the possibility } \\
\text { to compensate for a } \\
\text { European ageing population } \\
\text { through migration from the } \\
\text { MENA region. Migration } \\
\text { of highly skilled people is } \\
\text { favoured. Policies needed for } \\
\text { the medium skilled people. }\end{array}$ & ++ \\
\hline $\begin{array}{l}\text { Megapatterns of } \\
\text { global settlements } \\
\text { (Valsson and } \\
\text { Ulfarsson, 2012) }\end{array}$ & $\begin{array}{l}\text { Economic } \\
\text { Environmental } \\
\text { Technological }\end{array}$ & $\begin{array}{l}\text { Spatial localization; } \\
\text { Climate change, climate } \\
\text { variability; } \\
\text { Technological change; } \\
\text { Scientific/ and technical } \\
\text { innovation. }\end{array}$ & Global & $\begin{array}{l}\text { Migration towards the poles, } \\
\text { towards coastal areas, } \\
\text { towards central areas and } \\
\text { along spatial population } \\
\text { lines. }\end{array}$ & ++ \\
\hline $\begin{array}{l}\text { Migration pull } \\
\text { factors in OECD } \\
\text { (Lowell, 2009; } \\
\text { OECD, 2009) }\end{array}$ & $\begin{array}{l}\text { Economic } \\
\text { Political } \\
\text { Social }\end{array}$ & $\begin{array}{l}\text { Economic asymmetry, } \\
\text { economic differential, } \\
\text { economic gap; Labor } \\
\text { market and search for } \\
\text { jobs; Migration related } \\
\text { policies; } \\
\text { Demography; Education } \\
\text { and training; Network; } \\
\text { Social receptivity; Value } \\
\text { systems. }\end{array}$ & $\begin{array}{l}\text { Cross- } \\
\text { regional }\end{array}$ & $\begin{array}{l}\text { Strong and permanent flow } \\
\text { of mixed skilled migrants; } \\
\text { Moderate permanent migra- } \\
\text { tion flow associated with } \\
\text { active recruitment; Moderate } \\
\text { and temporary migration } \\
\text { flows of skilled migrants; } \\
\text { Reduced flows of migration } \\
\text { restricted to family, or even } \\
\text { negative migration flows. }\end{array}$ & + \\
\hline $\begin{array}{l}\text { Forecasting } \\
\text { World's population } \\
\text { (Bongaarts and } \\
\text { Bulatao, 2000) }\end{array}$ & $\begin{array}{l}\text { Economic } \\
\text { Political }\end{array}$ & $\begin{array}{l}\text { Economic asymmetry, } \\
\text { economic differential, } \\
\text { economic gap; } \\
\text { Globalization level; } \\
\text { Economic demand, } \\
\text { market and trade; } \\
\text { Migration related } \\
\text { policies. }\end{array}$ & Global & $\begin{array}{l}\text { Stable international migra- } \\
\text { tion towards traditional } \\
\text { industrialized immigration } \\
\text { countries, more unpredict- } \\
\text { able intra-regional migration } \\
\text { towards existing and emerg- } \\
\text { ing/new poles of attraction. }\end{array}$ & + \\
\hline
\end{tabular}




\begin{tabular}{|c|c|c|c|c|c|}
\hline Reference & Dimension & Drivers & Scale & Pattern & Relevance \\
\hline $\begin{array}{l}\text { FAO perspectives } \\
\text { for } 2050 \text { on food } \\
\text { and agriculture } \\
\text { (Conforti, 2011) }\end{array}$ & Economic & $\begin{array}{l}\text { Population/resource } \\
\text { ratio; Income per capita. }\end{array}$ & Global & $\begin{array}{l}\text { Outmigration from regions } \\
\text { with low income per capita. }\end{array}$ & + \\
\hline $\begin{array}{l}\text { Sub-Saharan } \\
\text { African migration: } \\
\text { Patterns and } \\
\text { Spillovers } \\
\text { (Gonzalez-Garcia } \\
\text { et al., 2016) }\end{array}$ & $\begin{array}{l}\text { Economic } \\
\text { Social }\end{array}$ & $\begin{array}{l}\text { Economic differential } \\
\text { with developed } \\
\text { countries; } \\
\text { Demography. }\end{array}$ & $\begin{array}{l}\text { R e g i o n a l } \\
\text { (SSA) }\end{array}$ & $\begin{array}{l}\text { Projects larger migration flow } \\
\text { due to demographic growth } \\
\text { towards advanced economies. } \\
\text { Predict } 2,3 \text { percent of OECD } \\
\text { countries population are mi- } \\
\text { grants from SSA in } 2050 \text {. }\end{array}$ & + \\
\hline $\begin{array}{l}\text { Modeling internal } \\
\text { migration flows } \\
\text { in sub-Saharan } \\
\text { Africa using census } \\
\text { microdata (Garcia } \\
\text { et al., 2015) }\end{array}$ & $\begin{array}{l}\text { Economic } \\
\text { Social } \\
\text { Enviornmental }\end{array}$ & $\begin{array}{l}\text { Active population; } \\
\text { Demography; } \\
\text { Distance; Rainfall }\end{array}$ & $\begin{array}{l}\text { Sub- } \\
\text { Regional } \\
\text { (10 SSA' } \\
\text { countries) }\end{array}$ & $\begin{array}{l}\text { No specific patterns, but test } \\
\text { the predictive capacity of } \\
\text { different gravity-type spatial } \\
\text { interaction models. }\end{array}$ & +- \\
\hline $\begin{array}{l}2017 \text { revision of } \\
\text { the UN World } \\
\text { Population } \\
\text { Prospects } \\
\text { (UNDESA, 2017) }\end{array}$ & $\begin{array}{l}\text { Economic } \\
\text { Social } \\
\text { Political }\end{array}$ & $\begin{array}{l}\text { Economic asymmetry, } \\
\text { economic differential, } \\
\text { economic gap; } \\
\text { Demography; } \\
\text { Crises }\end{array}$ & Global & $\begin{array}{l}\text { International migration are } \\
\text { due to large and persistent } \\
\text { economic and demographic } \\
\text { asymmetries between } \\
\text { countries. Top net receivers } \\
\text { of international migrants (> } \\
\text { 100,000/year) are the United } \\
\text { States of America, Germany, } \\
\text { Canada, the United Kingdom } \\
\text { of Great Britain and Northern } \\
\text { Ireland, Australia and the } \\
\text { Russian Federation. Coun- } \\
\text { tries with top net emigration } \\
\text { (> 100,000/year) are India, } \\
\text { Bangladesh, China, Paki- } \\
\text { stan, and Indonesia. }\end{array}$ & +- \\
\hline
\end{tabular}


Table 2 Characteristics of 17 futures studies focusing on foresight

\begin{tabular}{|c|c|c|c|c|c|}
\hline Reference & Dimension & Drivers & Scale & Pattern & Relevance \\
\hline $\begin{array}{l}\text { Many more to } \\
\text { come? Migration } \\
\text { from and within } \\
\text { Africa (EU/JRC, } \\
\text { 2018) }\end{array}$ & $\begin{array}{l}\text { Economic } \\
\text { Political } \\
\text { Social } \\
\text { Environmental }\end{array}$ & $\begin{array}{l}\text { Demography; } \\
\text { Socio-economic } \\
\text { development; } \\
\text { Climate change. }\end{array}$ & $\begin{array}{l}\text { Regional } \\
\text { (Africa) }\end{array}$ & $\begin{array}{l}\text { Three scenarios: } \\
\text { Scenario 1: continuation of current } \\
\text { socio-economic development, } \\
\text { population growth, and migration } \\
\text { intensity trends. } \\
\text { Scenario 2: economic growth } \\
\text { triggered by more direct } \\
\text { investments, creation of } \\
\text { employment in the formal } \\
\text { economy, better access to } \\
\text { education, faster decline in } \\
\text { fertility rates. } \\
\text { Scenario 3: climate change } \\
\text { producing extended heat waves, } \\
\text { higher surface temperatures } \\
\text { and disruptions in water cycles } \\
\text { particularly affecting populated } \\
\text { arid regions (Maghreb, Egypt, } \\
\text { Sudan, parts of Southern Africa } \\
\text { and the Big Lakes). }\end{array}$ & ++ \\
\hline $\begin{array}{l}\text { Regional Migration } \\
\text { Governance in the } \\
\text { African Continent } \\
\text { (Fioramonti and } \\
\text { Nshimby, 2016) }\end{array}$ & $\begin{array}{l}\text { Economic } \\
\text { political }\end{array}$ & $\begin{array}{l}\text { Nature of growth in } \\
\text { Africa; } \\
\text { Political system; } \\
\text { Regional governance } \\
\text { regimes. }\end{array}$ & $\begin{array}{l}\text { Regional } \\
\text { (Africa) }\end{array}$ & $\begin{array}{l}\text { The role of internal economic } \\
\text { drivers making "home" repulsive } \\
\text { or attractive. }\end{array}$ & ++ \\
\hline $\begin{array}{l}\text { IIED-Africa's } \\
\text { Evolving Food } \\
\text { Systems (Jayne et } \\
\text { al., 2014) }\end{array}$ & $\begin{array}{l}\text { Economic } \\
\text { Environmental } \\
\text { Political } \\
\text { Technological }\end{array}$ & $\begin{array}{l}\text { Food and energy } \\
\text { prices; The scope of } \\
\text { urban income growth; } \\
\text { Youth employment; } \\
\text { Climate change, } \\
\text { climate variability; } \\
\text { Soil quality; Migration } \\
\text { and investment } \\
\text { policies; Farm } \\
\text { structure. }\end{array}$ & $\begin{array}{l}\text { Regional } \\
\text { (Africa) }\end{array}$ & $\begin{array}{l}4 \text { scenarios. In the Latifundia } \\
\text { scenario there is outmigration } \\
\text { from rural areas experiencing land } \\
\text { scarcity. Availability of unused } \\
\text { land would favour voluntary rural- } \\
\text { rural migration. }\end{array}$ & ++ \\
\hline $\begin{array}{l}\text { Global migration } \\
\text { futures: Using } \\
\text { scenarios to explore } \\
\text { future migration in } \\
\text { the Horn of Africa \& } \\
\text { Yemen ((RMMS and } \\
\text { IMI, 2012) }\end{array}$ & $\begin{array}{l}\text { Economic } \\
\text { Political }\end{array}$ & $\begin{array}{l}\text { Economic growth; } \\
\text { Capacity of the state; } \\
\text { Military conflict }\end{array}$ & $\begin{array}{l}\text { Regional } \\
\text { (Horn of } \\
\text { Africa \& } \\
\text { Yemen) }\end{array}$ & $\begin{array}{l}\text { The Cash Baby! scenario induces } \\
\text { large internal rural to urban } \\
\text { migration of subsistence farmers } \\
\text { and pastoralist and external } \\
\text { migration of refugees and } \\
\text { displaced people. International } \\
\text { migration concerns students and } \\
\text { skilled people and become more } \\
\text { circular (intraregional migration). } \\
\text { The Jigsaw puzzle scenario } \\
\text { induces a migration pattern with } \\
\text { both flows of in-migrants to a } \\
\text { more stabilized region as well as } \\
\text { emigration of a diversity of people } \\
\text { to a diversity of destinations. }\end{array}$ & ++ \\
\hline
\end{tabular}




\begin{tabular}{|c|c|c|c|c|c|}
\hline Reference & Dimension & Drivers & Scale & Pattern & Relevance \\
\hline $\begin{array}{l}\text { The Future of } \\
\text { International } \\
\text { Migration to OECD } \\
\text { Countries (di Mattia } \\
\text { and Cassan, 2009; } \\
\text { OECD, 2009; Talwar, } \\
2009 \text { ) }\end{array}$ & $\begin{array}{l}\text { Economic } \\
\text { Political } \\
\text { Social }\end{array}$ & $\begin{array}{l}\text { Income inequalities in } \\
\text { non OECD countries; } \\
\text { Growth level in OECD } \\
\text { countries: } \\
\text { Global Governance, } \\
\text { institutional and socio- } \\
\text { political frameworks, } \\
\text { Geopolitical factors; } \\
\text { Demography; } \\
\text { Education and training; } \\
\text { Network; Social } \\
\text { development level in } \\
\text { the countries of origin. }\end{array}$ & $\begin{array}{l}\text { Cross- } \\
\text { regional }\end{array}$ & $\begin{array}{l}\text { Five scenarios: Progress for } \\
\text { All; OECD Long Boom; Uneven } \\
\text { Progress; Globalisation Falters; } \\
\text { Decoupled Destinies. Each } \\
\text { scenario is associated with } \\
\text { different migration patterns }\end{array}$ & ++ \\
\hline $\begin{array}{l}\text { International } \\
\text { migration study } \\
\text { (OECD, 2016a) }\end{array}$ & $\begin{array}{l}\text { Economic } \\
\text { Political }\end{array}$ & $\begin{array}{l}\text { Economic } \\
\text { asymmetry, } \\
\text { economic differential, } \\
\text { economic gap; } \\
\text { Global Governance, } \\
\text { institutional and } \\
\text { socio-political } \\
\text { frameworks, } \\
\text { geopolitical factors; } \\
\text { Migration related } \\
\text { policies. }\end{array}$ & Global & $\begin{array}{l}4 \text { scenarios: Slower shifting } \\
\text { wealth; SDG success; Crisis } \\
\text { with attempt for co-operation; } \\
\text { Rapid automation and conflicts. } \\
\text { Each scenario lead to a differ- } \\
\text { ent migratory pattern. }\end{array}$ & + \\
\hline $\begin{array}{l}\text { Territorial } \\
\text { foresight in Mali } \\
\text { and Madagascar } \\
\text { (Bourgeois et al., } \\
\text { 2016b, 2016a) }\end{array}$ & $\begin{array}{l}\text { Economic } \\
\text { Environmental } \\
\text { Political } \\
\text { Social }\end{array}$ & $\begin{array}{l}\text { Informal sector; } \\
\text { Infrastructure } \\
\text { development; Local } \\
\text { investment; Energy } \\
\text { (access); Policy } \\
\text { orientation; Local } \\
\text { capacity of actors; } \\
\text { Security. }\end{array}$ & $\begin{array}{l}\text { Intra- } \\
\text { national }\end{array}$ & No specific patterns. & + \\
\hline $\begin{array}{l}\text { The future of } \\
\text { poverty and } \\
\text { development } \\
\text { in Africa } \\
\text { (Ohiorhenuan, 2011) }\end{array}$ & $\begin{array}{l}\text { Economic } \\
\text { Political }\end{array}$ & $\begin{array}{l}\text { Competitiveness; } \\
\text { Governance. }\end{array}$ & $\begin{array}{l}\text { Regional } \\
\text { (Africa) }\end{array}$ & $\begin{array}{l}\text { Four scenarios. No clear } \\
\text { migration pattern. }\end{array}$ & + \\
\hline
\end{tabular}




\begin{tabular}{|c|c|c|c|c|c|}
\hline Reference & Dimension & Drivers & Scale & Pattern & Relevance \\
\hline $\begin{array}{l}\text { Migration } \\
\text { and Global } \\
\text { Environmental } \\
\text { Change Future } \\
\text { Challenges and } \\
\text { Opportunities } \\
\text { Future Scenarios. } \\
\text { (Government } \\
\text { Office for } \\
\text { Science, 2011) }\end{array}$ & $\begin{array}{l}\text { Economic } \\
\text { Political }\end{array}$ & $\begin{array}{l}\text { World growth rate; } \\
\text { Local governance }\end{array}$ & Global & $\begin{array}{l}4 \text { scenarios crossing growth } \\
\text { (high/low) X governance } \\
\text { (exclusive/inclusive): High/ } \\
\text { exclusive: 'gradual' or 'routine' } \\
\text { migration to richer economies } \\
\text { towards regional economic } \\
\text { growth poles. Increased } \\
\text { irregular migration by those } \\
\text { with assets and capitals, mainly } \\
\text { international migration. High/ } \\
\text { inclusive: voluntary migration } \\
\text { to richer economies towards } \\
\text { regional economic growth poles; } \\
\text { Facilitated circulation of migrant } \\
\text { populations, secure channels } \\
\text { for transmission of remittances } \\
\text { and diaspora involvement } \\
\text { in economic and political } \\
\text { development. Low/exclusive: } \\
\text { More skilled populations from } \\
\text { poorer countries relocate to } \\
\text { richer economies, limited internal } \\
\text { migration of skilled workers } \\
\text { in urban centres of poorer } \\
\text { economies; Increased irregular } \\
\text { migration by those with assets } \\
\text { and capital. Low/inclusive: } \\
\text { Low demand for international } \\
\text { migrants, substantial internal } \\
\text { migration to areas of higher } \\
\text { growth (regional growth poles, } \\
\text { coastal areas). }\end{array}$ & + \\
\hline $\begin{array}{l}\text { Future } \\
\text { Agriculture - } \\
\text { livestock, crops } \\
\text { and land use" } \\
\text { (Öborn et al., } \\
\text { 2011) }\end{array}$ & $\begin{array}{l}\text { Economic } \\
\text { Environmental } \\
\text { Political }\end{array}$ & $\begin{array}{l}\text { Labor; } \\
\text { Climate change, } \\
\text { climate variability; } \\
\text { Migration related } \\
\text { policies. }\end{array}$ & Global & $\begin{array}{l}\text { Three patterns resulting from } \\
\text { different migration flows: } \\
\text { concentration of large cities, } \\
\text { growth of town centres and } \\
\text { developed rural areas. }\end{array}$ & + \\
\hline $\begin{array}{l}\text { Millenium } \\
\text { economic } \\
\text { assessment } \\
\text { Order from } \\
\text { Strength scenario } \\
\text { (Reilly and } \\
\text { Willenbockel, } \\
\text { 2010) }\end{array}$ & $\begin{array}{l}\text { Economic } \\
\text { Technical } \\
\text { Environmental }\end{array}$ & $\begin{array}{l}\text { Level of Food } \\
\text { insecurity; } \\
\text { Level of farm outputs; } \\
\text { Climate change, } \\
\text { climate variability }\end{array}$ & $\begin{array}{l}\text { Global/ } \\
\text { regional }\end{array}$ & $\begin{array}{l}\text { Mass migration from southern to } \\
\text { West and East Africa. }\end{array}$ & + \\
\hline $\begin{array}{l}\text { MedAction } \\
\text { European project } \\
\text { (Kok et al., 2006) }\end{array}$ & $\begin{array}{l}\text { Environmental } \\
\text { Technological }\end{array}$ & $\begin{array}{l}\text { Water; } \\
\text { ICT; Technological } \\
\text { change; Scientific and } \\
\text { technical innovation. }\end{array}$ & $\begin{array}{l}\text { Cross- } \\
\text { regional }\end{array}$ & $\begin{array}{l}\text { Migration flows increase in all } \\
\text { scenarios at different paces; } \\
\text { Water situation is a push of pull } \\
\text { factor. }\end{array}$ & + \\
\hline
\end{tabular}




\begin{tabular}{|c|c|c|c|c|c|}
\hline Reference & Dimension & Drivers & Scale & Pattern & Relevance \\
\hline $\begin{array}{l}\text { Foresighting food, } \\
\text { rural and agrifutures } \\
\text { and (SCAR-CWG, } \\
2007 \text { ) }\end{array}$ & Environmental & $\begin{array}{l}\text { Climate change, } \\
\text { climate variability; } \\
\text { Energy; Water }\end{array}$ & Global & $\begin{array}{l}\text { Migration out of regions prone } \\
\text { to repeated climate shocks. }\end{array}$ & + \\
\hline $\begin{array}{l}\text { Alternatives futures } \\
\text { for global food and } \\
\text { agriculture (OECD, } \\
2016 b \text { ) }\end{array}$ & $\begin{array}{l}\text { Political } \\
\text { Social } \\
\text { Technological }\end{array}$ & $\begin{array}{l}\text { International } \\
\text { cooperation; } \\
\text { Attitudes towards } \\
\text { sustainable } \\
\text { behaviors; } \\
\text { Technological } \\
\text { innovation. }\end{array}$ & Global & $\begin{array}{l}3 \text { scenarios: Individual, Fossil } \\
\text { Fuel-Driven Growth Citizen- } \\
\text { Driven, Sustainable Growth; } \\
\text { Fast, Globally-Driven Growth. } \\
\text { A stronger flow of labour out } \\
\text { of agriculture-related sectors } \\
\text { in the "Fast scenario" with } \\
\text { workers moving to other } \\
\text { manufacturing and service } \\
\text { sectors. These flows are } \\
\text { considered to be smaller in } \\
\text { the "Individual scenario". }\end{array}$ & +- \\
\hline $\begin{array}{l}\text { Future change and } \\
\text { policy responses } \\
\text { for EU food safety } \\
\text { and security (Food } \\
\text { Chain Evaluation } \\
\text { Consortium, 2014) }\end{array}$ & Environmental & $\begin{array}{l}\text { Climate change, } \\
\text { climate variability. }\end{array}$ & $\begin{array}{l}\text { Regional } \\
\text { (EU) }\end{array}$ & "Environmental migration". & +- \\
\hline $\begin{array}{l}\text { African Futures } \\
2050 \text { The next forty } \\
\text { years (Cilliers et al., } \\
2011 \text { ) }\end{array}$ & $\begin{array}{l}\text { Economic } \\
\text { Social } \\
\text { Political } \\
\text { Environmental }\end{array}$ & $\begin{array}{l}\text { Economic growth; } \\
\text { Agriculture; } \\
\text { Demography; } \\
\text { Governance; } \\
\text { Natural resources }\end{array}$ & $\begin{array}{l}\text { Regional } \\
\text { (Africa) }\end{array}$ & $\begin{array}{l}\text { Four alternative African } \\
\text { futures crossing global } \\
\text { context (friendly vs harsh) and } \\
\text { African governance (weak/ } \\
\text { parasitic vs development } \\
\text { focused): Opportunities lost; } \\
\text { Politics of the belly; Arrested } \\
\text { development; African } \\
\text { renaissance. Only patter of } \\
\text { migration is associated with } \\
\text { climate change. }\end{array}$ & +- \\
\hline $\begin{array}{l}\text { GEO } 4 \text { Global } \\
\text { Environment } \\
\text { Outlook (Martino } \\
\text { and Zommers, } \\
\text { 2007) }\end{array}$ & $\begin{array}{l}\text { Economic } \\
\text { Social } \\
\text { Political } \\
\text { Technological }\end{array}$ & $\begin{array}{l}\text { Globalization; } \\
\text { Global Governance, } \\
\text { institutional and } \\
\text { socio-political } \\
\text { frameworks, } \\
\text { geopolitical } \\
\text { factors (including } \\
\text { international } \\
\text { migration policies) } \\
\text { Demography; } \\
\text { Social receptivity; } \\
\text { Value systems; } \\
\text { Technological } \\
\text { change; Scientific } \\
\text { and technical } \\
\text { innovation. }\end{array}$ & Global & $\begin{array}{l}\text { Migration due to conflict and } \\
\text { environmental degradation or } \\
\text { extreme climatic events, such } \\
\text { as out-migration of people } \\
\text { depending on endangered } \\
\text { ecosystems, from coastal } \\
\text { areas due to the rise of sea } \\
\text { level. }\end{array}$ & +- \\
\hline
\end{tabular}


Table 3. Characteristics of 12 other analytical futures studies

\begin{tabular}{|c|c|c|c|c|c|}
\hline Reference & Dimension & Drivers & Scale & Pattern & Relevance \\
\hline $\begin{array}{l}\text { African migration: } \\
\text { trends, patterns, } \\
\text { drivers (Flahaux } \\
\text { and De Haas, } \\
\text { 2016) }\end{array}$ & $\begin{array}{l}\text { Economic } \\
\text { Political }\end{array}$ & $\begin{array}{l}\text { Development } \\
\text { level; } \\
\text { National } \\
\text { migration } \\
\text { policies. }\end{array}$ & $\begin{array}{l}\text { Regional } \\
\text { (Africa) }\end{array}$ & $\begin{array}{l}\text { Does not include future } \\
\text { patterns but indicates trends } \\
\text { such as: More long-distance } \\
\text { international migration } \\
\text { from countries with higher } \\
\text { development level; More short- } \\
\text { distance regional migration from } \\
\text { countries with low development } \\
\text { levels. }\end{array}$ & ++ \\
\hline $\begin{array}{l}\text { Connecting with } \\
\text { migrant: a global } \\
\text { diaspora profile } \\
\text { (OECD, 2012) }\end{array}$ & $\begin{array}{l}\text { Economic } \\
\text { Political } \\
\text { Social }\end{array}$ & $\begin{array}{l}\text { Employment } \\
\text { attractiveness } \\
\text { differential; } \\
\text { Migration } \\
\text { policies; } \\
\text { Historical, } \\
\text { colonial, } \\
\text { linguistic links }\end{array}$ & Global & $\begin{array}{l}\text { Out-migration from SSA to } \\
\text { Europe of educated workers but } \\
\text { also limits due to immigration } \\
\text { policies associated with } \\
\text { growing flows of "south-south" } \\
\text { migration in Africa. Countries } \\
\text { with higher growth rate such } \\
\text { as Botswana, Namibia, South } \\
\text { Africa or Gabon could become } \\
\text { attractive for more educated } \\
\text { people. }\end{array}$ & ++ \\
\hline $\begin{array}{l}\text { Sub-Saharan } \\
\text { African } \\
\text { urbanization and } \\
\text { global climate } \\
\text { change (Parnell } \\
\text { and Walawege, } \\
\text { 2011) }\end{array}$ & Social & $\begin{array}{l}\text { Natural } \\
\text { population } \\
\text { growth in cities }\end{array}$ & $\begin{array}{l}\text { Regional } \\
\text { (SSA) }\end{array}$ & $\begin{array}{l}\text { Natural population growth in the } \\
\text { cities is more important than } \\
\text { climate change to explain future } \\
\text { settlement patterns in Africa. }\end{array}$ & ++ \\
\hline $\begin{array}{l}\text { Trends and } \\
\text { dynamics of } \\
\text { international } \\
\text { migration in } \\
\text { Western Africa } \\
\text { (Bossard and } \\
\text { Trémolières, 2010) }\end{array}$ & $\begin{array}{l}\text { Environmental } \\
\text { Social }\end{array}$ & $\begin{array}{l}\text { Climate } \\
\text { change; } \\
\text { Natural } \\
\text { resources } \\
\text { Demography. }\end{array}$ & $\begin{array}{l}\text { Regional } \\
\text { (west } \\
\text { Africa) }\end{array}$ & $\begin{array}{l}\text { Continued growth of } \\
\text { international migration fuelled } \\
\text { by SSA. }\end{array}$ & ++ \\
\hline $\begin{array}{l}\text { Drivers of change } \\
\text { in agriculture } \\
\text { (Hazell and Wood, } \\
\text { 2008) }\end{array}$ & $\begin{array}{l}\text { Economic } \\
\text { Political } \\
\text { Social }\end{array}$ & $\begin{array}{l}\text { Employment } \\
\text { attractiveness } \\
\text { differential; } \\
\text { War and } \\
\text { conflicts. }\end{array}$ & Global & $\begin{array}{l}2 \text { types of migration: a rural- } \\
\text { urban migration determined by } \\
\text { a "pull-out of agriculture" factor } \\
\text { due to the attractiveness of } \\
\text { better jobs in richer and growing } \\
\text { economies, and a distress } \\
\text { migration where households } \\
\text { compensate declining income } \\
\text { with jobs in other low-income } \\
\text { activities. }\end{array}$ & ++ \\
\hline $\begin{array}{l}\text { Issues and trends } \\
\text { in international } \\
\text { migration in sub- } \\
\text { Saharan Africa } \\
\text { (Adepoju, 2010) }\end{array}$ & $\begin{array}{l}\text { Economic } \\
\text { Political } \\
\text { Social }\end{array}$ & $\begin{array}{l}\text { Economic } \\
\text { situation; } \\
\text { Employment } \\
\text { Political } \\
\text { situation; } \\
\text { Inequality and } \\
\text { poverty. }\end{array}$ & $\begin{array}{l}\text { Regional } \\
\text { (SSA) }\end{array}$ & $\begin{array}{l}\text { Flow of legal and illegal } \\
\text { migrants. }\end{array}$ & \pm \\
\hline
\end{tabular}




\begin{tabular}{|c|c|c|c|c|c|}
\hline Reference & Dimension & Drivers & Scale & Pattern & Relevance \\
\hline $\begin{array}{l}\text { The future of food } \\
\text { and agriculture } \\
\text { - Trends and } \\
\text { challenges (FAO, } \\
\text { 2017) }\end{array}$ & $\begin{array}{l}\text { Economic } \\
\text { Social } \\
\text { Political } \\
\text { Environmental }\end{array}$ & $\begin{array}{l}\text { Employment } \\
\text { opportunities; } \\
\text { Demography } \\
\text { (population } \\
\text { growth); } \\
\text { Conflicts and } \\
\text { crises; } \\
\text { Climate } \\
\text { change. }\end{array}$ & Global & $\begin{array}{l}\text { No migration scenarios, } \\
\text { but two migration patterns: } \\
\text { Distress migration due to } \\
\text { a combination of natural } \\
\text { disasters due to adverse } \\
\text { effects of climate change } \\
\text { and conflicts; Non-distress } \\
\text { migration due to the } \\
\text { differential in employment } \\
\text { opportunities and socio- } \\
\text { economic conditions. }\end{array}$ & +- \\
\hline $\begin{array}{l}\text { The future of } \\
\text { sustainability } \\
\text { and food and } \\
\text { agriculture } \\
\text { (Giovannucci et al., } \\
2012 \text { ) }\end{array}$ & $\begin{array}{l}\text { Environmental } \\
\text { Technological }\end{array}$ & $\begin{array}{l}\text { Land; Water; } \\
\text { Farm structure. }\end{array}$ & Global & $\begin{array}{l}\text { Rural migration from places } \\
\text { facing water scarcity, } \\
\text { pressure on land and } \\
\text { farming structures reducing } \\
\text { local employment. }\end{array}$ & +- \\
\hline $\begin{array}{l}\text { The Big Picture } \\
\text { (Saritas and Smith, } \\
\text { 2011) }\end{array}$ & Environmental & Climate change & Global & No specific pattern. & +- \\
\hline $\begin{array}{l}\text { Impact of IT } \\
\text { on migration } \\
\text { intentions in rural } \\
\text { communities } \\
\text { (Moon et al., 2010) }\end{array}$ & Technological & $\begin{array}{l}\text { Digital gap } \\
\text { between rural } \\
\text { and urban } \\
\text { areas }\end{array}$ & $\begin{array}{l}\text { National } \\
\text { (Korea) }\end{array}$ & $\begin{array}{l}\text { The IT gap determines rural } \\
\text { to urban flows. }\end{array}$ & +- \\
\hline $\begin{array}{l}\text { Foresight for smart } \\
\text { globalization } \\
\text { (Jhirad et al., } \\
\text { 2009) }\end{array}$ & $\begin{array}{l}\text { Economic } \\
\text { Environmental } \\
\text { Political }\end{array}$ & $\begin{array}{l}\text { Economic } \\
\text { inequality; } \\
\text { State of } \\
\text { ecosystems; } \\
\text { Geopolitical } \\
\text { relationships. }\end{array}$ & Global & Rural to urban migration. & +- \\
\hline $\begin{array}{l}\text { Challenges for } \\
\text { Africa-Europe } \\
\text { relations - A } \\
\text { chance to get it } \\
\text { right (Mackie et } \\
\text { al., 2018) }\end{array}$ & Not specified & Not specified & $\begin{array}{l}\text { Inter- } \\
\text { regional } \\
\text { (Africa - } \\
\text { Europe) }\end{array}$ & $\begin{array}{l}\text { No pattern analysis. It } \\
\text { discusses the place of } \\
\text { migration in future Africa- } \\
\text { Europe relationship. }\end{array}$ & +- \\
\hline
\end{tabular}


Annex 5: Plausible scenarios for rural migration based on future states of rural areas and global alternative futures

The figure below displays the seven scenarios elaborated by Bourgeois (2015) about plausible rural transformation scenarios along two axes, combining respectively the level of investment in rural areas (vertical axis) and the relation between food consumption and food production patterns (horizontal axis).

\section{Crossing the future links between
consumption and production and \\ Crossing the future links between
consumption and production and development policies}

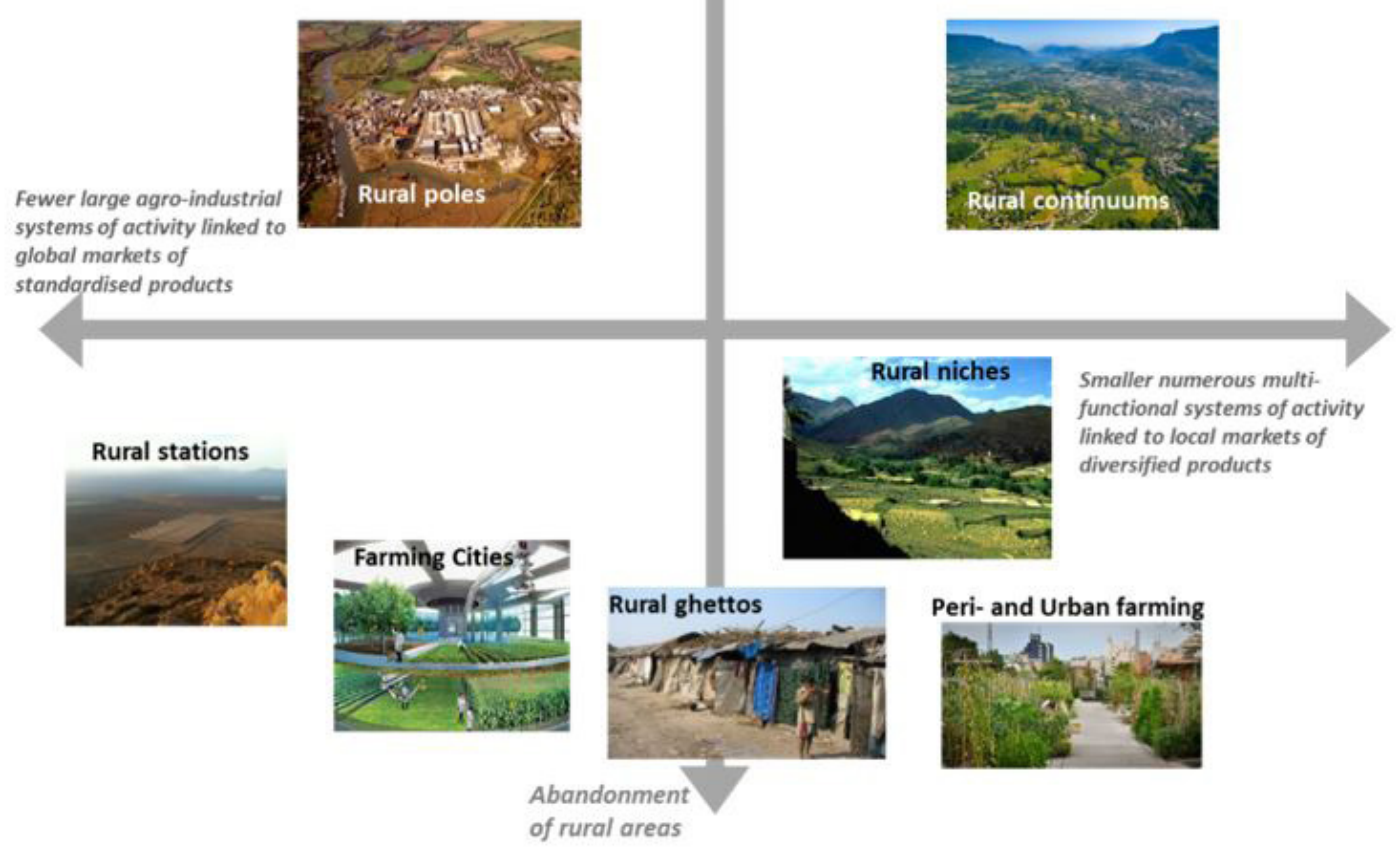

Revitalisation of rural areas

Source: Complete picture from Bourgeois (2015). What Future for Rural Areas? Seven plausible rural transformations.

Photographs:

Rural poles: @East of England Broadband Network (E2BN); Rural continuums: @Antoine Berger; Rural Niches: (c) Board of Regents of the University of Wisconsin System; Rural stations: CFarms Not Factories; Farming cities: @Chris Jacobs; Rural Ghettos: @Mercopress; Peri- and Urban farming: @Alva Lim.

The table below displays the drivers of each scenario, the details of each scenario, and where they could take place in sub-Saharan Africa: 


\begin{tabular}{|c|c|c|}
\hline Drivers & Scenarios & Where in sub-Saharan Africa \\
\hline $\begin{array}{l}\text { Consumers' preferences for } \\
\text { food price above food quality } \\
\text { and safety; Globalization of } \\
\text { food trade; Concentration and } \\
\text { vertical integration of food chains; } \\
\text { Automation of production; Land } \\
\text { availability. }\end{array}$ & $\begin{array}{l}\text { Rural stations. Gigantic automated } \\
\text { agri-plants employ a limited number } \\
\text { of workers, unless local poverty } \\
\text { makes human labour cheaper. Highly } \\
\text { specialized, spatially isolated, hyper- } \\
\text { connected to markets through roads, } \\
\text { railways, air and maritime freight, and } \\
\text { ICT. }\end{array}$ & $\begin{array}{l}\text { Not very suited for SSA, possibly } \\
\text { Namibia; mostly in large and } \\
\text { less populated areas in parts } \\
\text { of South America, Canada and } \\
\text { United States of America, Eastern } \\
\text { Europe, Caucasus, Russian } \\
\text { Federation, Australia, and } \\
\text { mainland China. }\end{array}$ \\
\hline $\begin{array}{l}\text { Preference for urban life; Public } \\
\text { investment in urban areas; } \\
\text { Technological breakthrough; High } \\
\text { tech connectivity. }\end{array}$ & $\begin{array}{l}\text { Farming cities. High-tech } \\
\text { "agriculture" develops in highly } \\
\text { controlled environments. City agri- } \\
\text { buildings owned by municipalities or } \\
\text { private companies employ technicians } \\
\text { and produce a diversity of products. }\end{array}$ & $\begin{array}{l}\text { In densely populated areas of } \\
\text { more developed countries and as } \\
\text { part of all mega-cities }\end{array}$ \\
\hline $\begin{array}{l}\text { Urbanization; Preferences for } \\
\text { urban lifestyles; Demand for } \\
\text { diversified food products; Failure } \\
\text { of outsourcing food products; } \\
\text { Local culinary preferences; Lack of } \\
\text { public investment in remote rural } \\
\text { areas. }\end{array}$ & $\begin{array}{l}\text { Urban farming. City residents use } \\
\text { all available interstitial urban spaces } \\
\text { (wasteland, buildings, walls, roofs, } \\
\text { terraces...) to grow a diversity of } \\
\text { products. They are connected to } \\
\text { specific consumers through local } \\
\text { short segmented chains. }\end{array}$ & $\begin{array}{l}\text { In and around mega-cities } \\
\text { particularly in highly populated } \\
\text { emerging and developing } \\
\text { countries. }\end{array}$ \\
\hline $\begin{array}{l}\text { High-income consumers } \\
\text { preference for certified, high value } \\
\text { products, grown in specific areas; } \\
\text { Increased connectivity or proximity } \\
\text { between specialized producers } \\
\text { and specific consumers; Targeted } \\
\text { public and private investment. }\end{array}$ & $\begin{array}{l}\text { Rural niches. People find livelihood in } \\
\text { exploiting a comparative advantage } \\
\text { offered by local features in and } \\
\text { outside agriculture. Rural niches } \\
\text { attract private and public investment } \\
\text { targeting specific market segments } \\
\text { producing high quality, high added- } \\
\text { value products. }\end{array}$ & $\begin{array}{l}\text { In the most developed rural areas } \\
\text { where local resources make } \\
\text { the production of high quality } \\
\text { specialized products possible. }\end{array}$ \\
\hline $\begin{array}{l}\text { Diversion of public and private } \\
\text { investment to cities; Natural, } \\
\text { social, economic, and health } \\
\text { disasters; Remoteness of rural } \\
\text { areas; Misery of urban life for the } \\
\text { jobless. }\end{array}$ & $\begin{array}{l}\text { Rural ghettos. A marginalized } \\
\text { population survive through self- } \\
\text { subsistence in abandoned rural areas. } \\
\text { They seek employment in gigantic } \\
\text { agro-industries (rural stations) around } \\
\text { which they settle or through migration } \\
\text { of family members. }\end{array}$ & $\begin{array}{l}\text { In deeply rural areas, } \\
\text { mountainous areas and in the } \\
\text { vicinity of rural stations; also } \\
\text { where land concentration will } \\
\text { deprive people for the possibility } \\
\text { to properly settle. }\end{array}$ \\
\hline $\begin{array}{l}\text { Limited globalization with } \\
\text { restricted free flow of products; } \\
\text { Standardization of consumers' } \\
\text { preferences; Risk sharing } \\
\text { strategies of agri-food chains; } \\
\text { Selective public investment in rural } \\
\text { infrastructure where immediate } \\
\text { returns can be yielded. }\end{array}$ & $\begin{array}{l}\text { Rural poles large-scale core } \\
\text { industries transforming a limited } \\
\text { number of key products (tree crops, } \\
\text { grains, meat, but also non-food } \\
\text { products) and limiting production } \\
\text { risks by contracting production to a } \\
\text { plasma or clusters of smaller farms } \\
\text { or households supplying the core } \\
\text { industry. }\end{array}$ & $\begin{array}{l}\text { In the hinterlands between cities } \\
\text { and deeper rural areas, where } \\
\text { land is available and population } \\
\text { density not too high. }\end{array}$ \\
\hline $\begin{array}{l}\text { Shift of consumers preference } \\
\text { towards local products; } \\
\text { Technological breakthroughs } \\
\text { for more resilient yet profitable } \\
\text { farming systems; Public and } \\
\text { private investment in rural areas in } \\
\text { and outside agriculture; Failure of } \\
\text { globalisation to satisfy a diversified } \\
\text { demand; Direct connectivity } \\
\text { of producers and consumers; } \\
\text { Individual aspirations and } \\
\text { worldviews. }\end{array}$ & $\begin{array}{l}\text { Continuous food production and } \\
\text { transformation, and many non- } \\
\text { farm activities take place in small } \\
\text { diversified enterprises that are highly } \\
\text { connected to local markets and } \\
\text { operate in an environment providing } \\
\text { connectivity and employment } \\
\text { opportunities. "Farmers" have several } \\
\text { jobs and are directly connected to } \\
\text { markets and consumers. Quality of } \\
\text { life is similar to that of urban areas. }\end{array}$ & $\begin{array}{l}\text { In moderately dense areas around } \\
\text { small to medium size cities. }\end{array}$ \\
\hline
\end{tabular}


The next table displays correspondences between three of Dator's world orders (Dator, 2009) presented in section 2.2 and the plausible future states of rural areas presented above:

\begin{tabular}{|c|c|c|c|c|c|c|c|}
\hline & & & Scenar & f rural & formatic & & \\
\hline & $\begin{array}{l}\text { Rural } \\
\text { stations }\end{array}$ & $\begin{array}{l}\text { Farming } \\
\text { cities }\end{array}$ & $\begin{array}{l}\text { Urban } \\
\text { farming }\end{array}$ & $\begin{array}{l}\text { Rural } \\
\text { niches }\end{array}$ & $\begin{array}{l}\text { Rural } \\
\text { ghettos }\end{array}$ & $\begin{array}{l}\text { Rural } \\
\text { poles }\end{array}$ & $\begin{array}{l}\text { Rural } \\
\text { Continuums }\end{array}$ \\
\hline $\begin{array}{l}\text { Continued } \\
\text { Growth }\end{array}$ & $x x x$ & $x x x$ & $x x x$ & - & - & $x x x$ & - \\
\hline Discipline & - & - & $x x x$ & - & - & - & $x x x$ \\
\hline$\underline{\text { Collapse }}$ & - & - & $x x x$ & $x x x$ & $x x x$ & . & - \\
\hline
\end{tabular}

This articulation allows the development of a narrative for each scenario:

Narrative 1: Continued growth. A pattern similar to the trend observed so far takes place, with identical pull and push factors. As urbanization develops, and agricultural production gets more concentrated in large capital intensive/robotized production systems, agro-industrial clusters, and farming cities, rural people will tend to migrate more and more towards larger cities within their own countries, developing peri-urban farming, or towards more developed countries in their region/world (United States of America, Canada, Europe, Middle East, Australia). However, SSA international rural migrants would have to compete with other non-rural and rural migrants particularly from Asia. The poorest rural migrants will not be in a situation to compete with non-rural migrants, and preferential immigration policies in receiving countries shaped by job requirements as well as local social and cultural acceptability will also limit the out-migration options for rural people. As a result, many of them would live in rural ghettos in marginal rural areas or at the periphery of medium and large cities.

Narrative 2: Discipline. The refocusing of the economy and society on survival and fair distribution leads to the rehabilitation of rural areas as places providing possibilities for decent living conditions. SSA rural outmigration are limited as the living conditions offered in rural areas are not significantly less attractive than in urban areas and sometime the difference is no longer visible (rural continuums, farming cities). SSA rural migrants migrate by choice and personal preferences. There is no competition for outmigration.

Narrative 3: Collapse. This world order would trigger massive worldwide migration of the most vulnerable people (from Asia and Africa mainly) from the worst hit places of collapse towards safer places. Tens of millions of Asian migrants and African urban migrants would compete with SSA rural migrants. In this scenario, the best chances for potential SSA rural migrants would not be to migrate but to develop local survival strategies based on autarchy and subsistence farming (rural oasis). 


\section{Annex 6: Additional definitions}

Circular migration refers to recurrent movements between a place of origin and one or more places of destination, which involves more than one migration and return. In this respect, circular migration contrasts with conventional and statistical definitions of migration that consider a permanent change of residence related to a definitive or long term movement between origin and destination. It also differs from return migration and from commuting. Circular migration involves migrants sharing work, family and other aspects of their lives between two or more locations. It can occur at both internal and international levels (Graem, 2013).

Internally displaced person (IDP): Persons or groups who have been forced or obliged to flee or to leave their homes or places of habitual residence, in particular as a result of or in order to avoid the effects of armed conflict, situations of generalized violence, violations of human rights or natural or human-made disasters, and who have not crossed an internationally recognized State border (UNCHR, 1998).

International migration refers to movement of persons who leave their country of origin, or country of habitual residence, to establish themselves either permanently or temporarily (usually for over than 1 year) in another country. An international frontier is therefore crossed (IOM, 2011).

Internal migration refers to a movement of people from one area of a country to another area of the same country for the purpose or with the effect of establishing a new residence. This migration may be temporary or permanent. Internal migration includes: (i) rural to urban migration; (ii) rural to rural migration; (iii) urban to rural migration; and (iv) urban to urban migration (IOM, 2011).

Migrant. The term migrant is defined by (IOM) as "any person who is moving or has moved across an international border or within a State away from his/her habitual place of residence, regardless of (1) the person's legal status; (2) whether the movement is voluntary or involuntary; (3) what the causes for the movement are; or (4) what the length of the stay is". Migration is therefore the movement of a person or a group of persons, either across an international border, or within a state. This may encompass any kind of movement of people, whatever its length, composition and causes, including the migration of refugees, displaced persons, economic migrants, and persons moving for other purposes, and family reunification (IOM, 2011). However, there is no universal categorization of migrants, as each country has its own policies, legislation and statistics regarding migration.

Migration pattern. A migration pattern is a combination of features of migration (spatial scale, duration, volume, intensity, and direction) that endure through time and space, characterizing migration flows with a specific form and structure. Migration patterns can be related to specific groups of people (in terms of socioeconomic features) resulting in particular organizations (networks, associations, brotherhoods).

Refugee: Refugee According to the 1951 Refugee Convention (Article 1(A)(2)), a refugee is a person who is outside the country of his or her nationality and is unable or unwilling to avail him/herself of the protection of that country, because of a well-founded fear of being persecuted for reasons of race, religion, nationality, membership of a particular social group or political opinions (IOM 2011 and UNHCR I Glossary).

Rural and urban areas. No agreed definition exists. Most of the time, rural areas are defined in opposition to urban areas, and the definition of urban areas varies between countries, depending on size, functions, administrative status, etc. (AfDB, OECD, UNDP, 2015). Beyond the difficulty to set a standard definition, the idea of a clear division between an urban and a rural area misshapes the reality of what rural, urban, growing peri-urban and "rurban" areas are today. Remote rural areas still exist, particularly in SSA, but generally the improved access to ICTs, information, and to transportation networks, as well as better educational standards foster the movement of people, blurring the limits of the old rural - urban divide (Losch, 2015). Changing settlements, more integrated food systems, commuting and migration patterns and new lifestyles contribute to an interface where often population and activities cannot anymore be spatially categorised in a strict manner. 
Annex 7: Rural MHH and NMHH profiles: summary statistics for selected variables

\begin{tabular}{|c|c|c|c|c|c|c|c|c|c|}
\hline \multirow{3}{*}{ Variable } & \multicolumn{9}{|c|}{ RULIS Selected Countries } \\
\hline & \multicolumn{3}{|c|}{ Ghana } & \multicolumn{3}{|c|}{ Ethiopia } & \multicolumn{3}{|c|}{ Malawi } \\
\hline & MHHs & NMHHs & $\begin{array}{l}\text { t/chi } \\
\text { tests }\end{array}$ & MHHs & NMHHs & $\begin{array}{l}\text { t/chi } \\
\text { tests }\end{array}$ & MHHs & NMHHs & $\begin{array}{l}t / \text { chi }^{2} \\
\text { tests }\end{array}$ \\
\hline $\begin{array}{l}\text { Highest years of } \\
\text { education in household } \\
\text { (years) }\end{array}$ & 9.9 & 8.1 & $-10.66^{\star *}$ & 4.6 & 4.0 & $-4.47^{\star *}$ & 9.4 & 7.4 & $-11.23^{* *}$ \\
\hline $\begin{array}{l}\text { Female share of } \\
\text { household labor (\%) }\end{array}$ & 0.53 & 0.48 & $-2.46^{\star}$ & 0.53 & 0.50 & $-2.01^{*}$ & 0.54 & 0.52 & -1.75 \\
\hline $\begin{array}{l}\text { Household size (number } \\
\text { of household members) }\end{array}$ & 6.3 & 4.4 & $-13.59^{* *}$ & 5.1 & 5.3 & 0.35 & 4.5 & 4.9 & $3.36^{* *}$ \\
\hline $\begin{array}{l}\text { Size of land owned (in } \\
\text { ha) }\end{array}$ & 3.21 & 2.62 & $-3.13^{* *}$ & 1.43 & 1.16 & $-4.06^{* *}$ & 0.34 & 0.52 & $6.16^{\star *}$ \\
\hline $\begin{array}{l}\text { Total livestock owned } \\
\text { (heads) }\end{array}$ & 2.0 & 1.0 & $-4.99^{* *}$ & 3.4 & 3.0 & $-2.25^{\star}$ & 0.2 & 0.3 & $2.39^{*}$ \\
\hline $\begin{array}{l}\text { Age of the head of the } \\
\text { household (in years) }\end{array}$ & 49.4 & 46.8 & $-3.43^{* *}$ & n.a. & n.a. & n.a. & n.a. & n.a. & n.a. \\
\hline $\begin{array}{l}\text { household owns cell } \\
\text { phone (Yes) }\end{array}$ & $96.4 \%$ & $93.8 \%$ & 0.54 & $52.2 \%$ & $37.9 \%$ & $31.81^{* *}$ & $60.1 \%$ & $37.4 \%$ & $66.12^{* *}$ \\
\hline Solid roof (Yes) & $82.4 \%$ & $82.8 \%$ & 0.44 & $64.9 \%$ & $50.8 \%$ & $28.99 * *$ & $43.1 \%$ & $30.8 \%$ & $31.11^{* *}$ \\
\hline $\begin{array}{l}\text { Female-headed } \\
\text { household (Yes) }\end{array}$ & $20.8 \%$ & $26.4 \%$ & $5.98^{*}$ & n.a. & n.a. & n.a. & n.a. & n.a. & n.a. \\
\hline $\begin{array}{l}\text { Household experienced } \\
\text { weather, market or } \\
\text { disease related shocks } \\
\text { (Yes) }\end{array}$ & n.a. & n.a. & n.a. & $37.7 \%$ & $48.7 \%$ & $9.70^{* *}$ & $80.0 \%$ & $91.3 \%$ & $49.93^{* *}$ \\
\hline $\begin{array}{l}\text { Male share of household } \\
\text { labor }\end{array}$ & 0.47 & 0.44 & $-2.46^{\star}$ & 0.44 & 0.43 & -0.68 & 0.45 & 0.44 & -0.89 \\
\hline $\begin{array}{l}\text { Farm area operated } \\
\text { (in ha) }\end{array}$ & 3.3 & 2.6 & $-5.48^{\star *}$ & 1.4 & 1.2 & $-3.35^{\star *}$ & 0.71 & 0.73 & 0.41 \\
\hline $\begin{array}{l}\text { Coverage of social } \\
\text { assistance (Yes) }\end{array}$ & $1.1 \%$ & $0.7 \%$ & 1.49 & $25.2 \%$ & $24.8 \%$ & 0.07 & $20.7 \%$ & $28.6 \%$ & $9.1^{* *}$ \\
\hline $\begin{array}{l}\text { Access to extension } \\
\text { services (Yes) }\end{array}$ & n.a. & n.a. & n.a. & $67.0 \%$ & $60.9 \%$ & $11.07^{\star \star}$ & $45.6 \%$ & $46.3 \%$ & 0.05 \\
\hline
\end{tabular}




\begin{tabular}{|c|c|c|c|c|c|c|c|c|c|}
\hline \multirow[t]{2}{*}{ Variable } & \multicolumn{3}{|c|}{ Mali } & \multicolumn{3}{|c|}{ Nigeria } & \multicolumn{3}{|c|}{ Uganda } \\
\hline & MHHs & NMHHs & $\begin{array}{l}\text { t/chi } \\
\text { tests }\end{array}$ & MHHs & NMHHs & $\begin{array}{l}t / \mathrm{chi}^{2} \\
\text { tests }\end{array}$ & MHHs & NMHHs & $\begin{array}{l}\mathrm{t} / \mathrm{chi}^{2} \\
\text { tests }\end{array}$ \\
\hline $\begin{array}{l}\text { Highest years of } \\
\text { education in household } \\
\text { (years) }\end{array}$ & 8.4 & 6.2 & -1.14 & 9.2 & 7.94 & $-4.71^{\star *}$ & 7.7 & 7.3 & -1.06 \\
\hline $\begin{array}{l}\text { Female share of } \\
\text { household labor (\%) }\end{array}$ & 0.51 & 0.53 & $2.07^{*}$ & 0.53 & 0.51 & -1.56 & 0.48 & 0.50 & 0.60 \\
\hline $\begin{array}{l}\text { Household size (number } \\
\text { of household members) }\end{array}$ & 15.0 & 10.6 & $-6.67^{\star *}$ & 7.1 & 6.3 & $-4.93^{* *}$ & 7.5 & 5.6 & $-5.05^{\star *}$ \\
\hline Size of land owned (in ha) & 7.7 & 5.6 & $-3.17^{* *}$ & 0.33 & 0.50 & $4.55^{\star *}$ & 0.32 & 0.40 & 1.08 \\
\hline $\begin{array}{l}\text { Total livestock owned } \\
\text { (heads) }\end{array}$ & 3.4 & 3.5 & -0.23 & 0.4 & 1.2 & $3.68^{* *}$ & 1.4 & 0.8 & $-3.47^{* *}$ \\
\hline $\begin{array}{l}\text { Age of the head of the } \\
\text { household (in years) }\end{array}$ & 54.0 & 50.4 & -1.95 & n.a. & n.a. & n.a. & n.a. & n.a. & n.a. \\
\hline $\begin{array}{l}\text { household owns cell } \\
\text { phone (Yes) }\end{array}$ & $92.2 \%$ & $73.4 \%$ & $14.54^{* *}$ & $85.4 \%$ & $70.1 \%$ & $31.11^{* *}$ & $71.9 \%$ & $64.0 \%$ & 1.75 \\
\hline Solid roof (Yes) & $46.7 \%$ & $35.3 \%$ & 0.24 & n.a. & n.a. & n.a. & $77.1 \%$ & $65.9 \%$ & 3.78 \\
\hline $\begin{array}{l}\text { Female-headed } \\
\text { household (Yes) }\end{array}$ & $0.5 \%$ & $3.5 \%$ & $10.06^{* *}$ & n.a. & n.a. & n.a. & n.a. & n.a. & n.a. \\
\hline $\begin{array}{l}\text { Household experienced } \\
\text { weather, market or } \\
\text { disease related shocks } \\
\text { (Yes) }\end{array}$ & $67.7 \%$ & $69.1 \%$ & $5.72^{*}$ & $17.2 \%$ & $21.8 \%$ & $10.69^{* *}$ & $44.6 \%$ & $37.1 \%$ & 1.81 \\
\hline $\begin{array}{l}\text { Male share of household } \\
\text { labor }\end{array}$ & 0.49 & 0.46 & $-2.33^{*}$ & 0.41 & 0.42 & 1.14 & 0.50 & 0.43 & -1.86 \\
\hline $\begin{array}{l}\text { Farm area operated } \\
\text { (in ha) }\end{array}$ & 7.4 & 5.8 & $-3.04^{* *}$ & 0.65 & 0.90 & $3.18^{* *}$ & 1.9 & 2.0 & 0.45 \\
\hline $\begin{array}{l}\text { Coverage of social } \\
\text { assistance (Yes) }\end{array}$ & $24.1 \%$ & $15.8 \%$ & $8.76^{\star *}$ & $1.3 \%$ & $3.2 \%$ & 3.77 & na & na & na \\
\hline $\begin{array}{l}\text { Access to extension } \\
\text { services (Yes) }\end{array}$ & $21.6 \%$ & $27.6 \%$ & 3.08 & $1.1 \%$ & $6.0 \%$ & $11.15^{\star *}$ & $26.6 \%$ & $20.4 \%$ & 1.47 \\
\hline
\end{tabular}




\begin{tabular}{|c|c|c|c|c|c|c|c|c|c|}
\hline \multirow{3}{*}{ Variable } & \multicolumn{9}{|c|}{ RULIS Selected Countries } \\
\hline & \multicolumn{3}{|c|}{ Ghana } & \multicolumn{3}{|c|}{ Ethiopia } & \multicolumn{3}{|c|}{ Malawi } \\
\hline & MHHs & NMHHs & $\begin{array}{l}\mathrm{t} / \mathrm{chi}^{2} \\
\text { tests }\end{array}$ & MHHs & NMHHs & $\begin{array}{l}\text { t/chi } \\
\text { tests }\end{array}$ & MHHs & NMHHs & $\begin{array}{l}\text { t/chi }{ }^{2} \\
\text { tests }\end{array}$ \\
\hline $\begin{array}{l}\text { Access to irrigation } \\
\text { services (Yes) }\end{array}$ & $1.5 \%$ & $0.77 \%$ & 2.66 & $11.9 \%$ & $10.6 \%$ & 1.07 & $2.1 \%$ & $1.8 \%$ & 0.10 \\
\hline $\begin{array}{l}\text { Access to improved } \\
\text { sanitation (Yes) }\end{array}$ & $26.2 \%$ & $30.0 \%$ & 3.39 & $63.6 \%$ & $59.9 \%$ & $4.12^{*}$ & $75.1 \%$ & $66.0 \%$ & $11.0^{* *}$ \\
\hline $\begin{array}{l}\text { Access to safe } \\
\text { water (Yes) }\end{array}$ & $61.4 \%$ & $57.5 \%$ & 3.16 & $72.8 \%$ & $71.7 \%$ & 0.40 & $24.6 \%$ & $18.1 \%$ & $8.16^{* *}$ \\
\hline $\begin{array}{l}\text { Access to } \\
\text { electricity (Yes) }\end{array}$ & $41.4 \%$ & $41.0 \%$ & 0.02 & $34.0 \%$ & $28.5 \%$ & $10.0^{* *}$ & $14.7 \%$ & $3.3 \%$ & $88.56^{* *}$ \\
\hline $\begin{array}{l}\text { Household } \\
\text { obtaining credit } \\
\text { (Yes) }\end{array}$ & $16.7 \%$ & $10.3 \%$ & $21.20^{* *}$ & $24.8 \%$ & $24.4 \%$ & 0.05 & $24.9 \%$ & $20.0 \%$ & $4.26^{*}$ \\
\hline $\begin{array}{l}\text { Main dwelling walls } \\
\text { material - brick } \\
\text { (Yes) }\end{array}$ & $28.8 \%$ & $32.2 \%$ & 2.68 & $0.9 \%$ & $0.9 \%$ & 0.02 & $87.1 \%$ & $77.7 \%$ & $15.62^{\star *}$ \\
\hline $\begin{array}{l}\text { Dwelling has non- } \\
\text { dirt/non-mud floor } \\
\text { (Yes) }\end{array}$ & $81.8 \%$ & $83.2 \%$ & 0.66 & $4.3 \%$ & $4.8 \%$ & 0.32 & $37.5 \%$ & $19.4 \%$ & $57.84^{* *}$ \\
\hline $\begin{array}{l}\text { Household owns } \\
\text { dwelling (Yes) }\end{array}$ & $84.1 \%$ & $75.9 \%$ & $18.63^{* *}$ & $93.6 \%$ & $92.0 \%$ & 2.59 & $54.7 \%$ & $87.3 \%$ & $228.85^{\star *}$ \\
\hline $\begin{array}{l}\text { Raising livestock no } \\
\text { land (Yes) }\end{array}$ & n.a. & n.a. & n.a. & $6.4 \%$ & $7.5 \%$ & 1.09 & $20.1 \%$ & $5.7 \%$ & $46.21^{\star *}$ \\
\hline $\begin{array}{l}\text { Household owning } \\
\text { equine (Yes) }\end{array}$ & $9.1 \%$ & $6.6 \%$ & 3.77 & $41.8 \%$ & $35.2 \%$ & $13.27^{\star *}$ & $0.0 \%$ & $0.1 \%$ & 0.10 \\
\hline $\begin{array}{l}\text { Household owning } \\
\text { poultry (Yes) }\end{array}$ & $86.6 \%$ & $86.4 \%$ & 0.01 & $54.8 \%$ & $50.5 \%$ & $5.02^{*}$ & $81.8 \%$ & $79.9 \%$ & 0.30 \\
\hline $\begin{array}{l}\text { Household owning } \\
\text { small ruminants } \\
\text { (Yes) }\end{array}$ & $71.6 \%$ & $65.8 \%$ & $5.78^{*}$ & $58.5 \%$ & $53.6 \%$ & $6.52^{*}$ & $40.0 \%$ & $45.7 \%$ & 2.60 \\
\hline $\begin{array}{l}\text { Household owning } \\
\text { large ruminants } \\
\text { (Yes) }\end{array}$ & $20.5 \%$ & $17.3 \%$ & 2.90 & $75.6 \%$ & $72.7 \%$ & 3.01 & $6.9 \%$ & $11.8 \%$ & 3.42 \\
\hline $\begin{array}{l}\text { Number of } \\
\text { rooms household } \\
\text { members occupy }\end{array}$ & 2.7 & 2.1 & $-8.90^{\star *}$ & 1.8 & 1.7 & $-4.56^{\star *}$ & 2.3 & 2.2 & -0.68 \\
\hline
\end{tabular}




\begin{tabular}{|c|c|c|c|c|c|c|c|c|c|}
\hline \multirow[t]{2}{*}{ Variable } & \multicolumn{3}{|c|}{ Mali } & \multicolumn{3}{|c|}{ Nigeria } & \multicolumn{3}{|c|}{ Uganda } \\
\hline & MHHs & NMHHs & $\begin{array}{l}\text { t/chi }{ }^{2} \\
\text { tests }\end{array}$ & MHHs & NMHHs & $\begin{array}{l}\text { t/chi }{ }^{2} \\
\text { tests }\end{array}$ & MHHs & NMHHs & $\begin{array}{l}\text { t/chi }{ }^{2} \\
\text { tests }\end{array}$ \\
\hline $\begin{array}{l}\text { Access to irrigation } \\
\text { services (Yes) }\end{array}$ & $12.8 \%$ & $21.1 \%$ & $7.08^{\star *}$ & $0.0 \%$ & $1.5 \%$ & 3.66 & $5.6 \%$ & $1.6 \%$ & $4.92^{*}$ \\
\hline $\begin{array}{l}\text { Access to improved } \\
\text { sanitation (Yes) }\end{array}$ & $87.4 \%$ & $84.1 \%$ & $6.12^{*}$ & $10.8 \%$ & $5.6 \%$ & $13.33^{\star *}$ & $87.1 \%$ & $72.8 \%$ & $7.12^{\star *}$ \\
\hline $\begin{array}{l}\text { Access to safe } \\
\text { water (Yes) }\end{array}$ & $34.0 \%$ & $43.0 \%$ & $5.83^{\star}$ & $61.4 \%$ & $59.7 \%$ & 0.33 & $81.8 \%$ & $69.3 \%$ & $4.73^{*}$ \\
\hline $\begin{array}{l}\text { Access to } \\
\text { electricity (Yes) }\end{array}$ & $4.2 \%$ & $4.4 \%$ & 0.02 & $42.4 \%$ & $35.3 \%$ & $6.24^{*}$ & $1.4 \%$ & $3.0 \%$ & 0.59 \\
\hline $\begin{array}{l}\text { Household } \\
\text { obtaining credit } \\
\text { (Yes) }\end{array}$ & $29.3 \%$ & $24.7 \%$ & 2.01 & $8.5 \%$ & $4.2 \%$ & $12.34^{\star *}$ & n.a. & n.a. & n.a. \\
\hline $\begin{array}{l}\text { Main dwelling walls } \\
\text { material - brick } \\
\text { (Yes) }\end{array}$ & $10.0 \%$ & $9.4 \%$ & 0.07 & n.a. & n.a. & n.a. & $70.0 \%$ & $59.9 \%$ & 2.91 \\
\hline $\begin{array}{l}\text { Dwelling has non- } \\
\text { dirt/non-mud floor } \\
\text { (Yes) }\end{array}$ & $16.8 \%$ & $14.3 \%$ & 0.85 & n.a. & n.a. & n.a. & $19.2 \%$ & $26.5 \%$ & $5.57^{\star}$ \\
\hline $\begin{array}{l}\text { Household owns } \\
\text { dwelling (Yes) }\end{array}$ & $94.2 \%$ & $89.5 \%$ & $4.35^{\star}$ & n.a. & n.a. & n.a. & $90.8 \%$ & $71.3 \%$ & $66.45^{* *}$ \\
\hline $\begin{array}{l}\text { Raising livestock no } \\
\text { land (Yes) }\end{array}$ & n.a. & n.a. & n.a. & $0.0 \%$ & $0.3 \%$ & 0.89 & $1.6 \%$ & $0.8 \%$ & 0.47 \\
\hline $\begin{array}{l}\text { Household owning } \\
\text { equine (Yes) }\end{array}$ & $74.7 \%$ & $66.6 \%$ & $4.52^{*}$ & $0.0 \%$ & $2.9 \%$ & $8.09^{* *}$ & $0.0 \%$ & $0.3 \%$ & 0.10 \\
\hline $\begin{array}{l}\text { Household owning } \\
\text { poultry (Yes) }\end{array}$ & $77.1 \%$ & $63.7 \%$ & $11.92^{* *}$ & $47.0 \%$ & $47.2 \%$ & 0.00 & $97.8 \%$ & $99.9 \%$ & $11.23^{* *}$ \\
\hline $\begin{array}{l}\text { Household owning } \\
\text { small ruminants } \\
\text { (Yes) }\end{array}$ & $83.1 \%$ & $80.5 \%$ & 0.67 & $40.3 \%$ & $52.1 \%$ & $13.51^{* *}$ & $100 \%$ & $100 \%$ & - \\
\hline $\begin{array}{l}\text { Household owning } \\
\text { large ruminants } \\
\text { (Yes) }\end{array}$ & $76.5 \%$ & $70.5 \%$ & 2.68 & $3.7 \%$ & $21.4 \%$ & $47.81^{* *}$ & $96.7 \%$ & $99.8 \%$ & $8.80^{* *}$ \\
\hline $\begin{array}{l}\text { Number of } \\
\text { rooms household } \\
\text { members occupy }\end{array}$ & 6.2 & 5.5 & $-2.26^{\star}$ & n.a. & n.a. & n.a. & 2.9 & 2.3 & $-4.33^{* *}$ \\
\hline
\end{tabular}

Source: Authors' own computations based on RuLIS data. Note: MHHs and NMHHs stand for Migrant Households and Non-Migrant Households respectively. ${ }^{\star *}$ Significant at the $1 \%$ level. ${ }^{*}$ Significant at the $5 \%$ level 


\section{Annex 8: Results from PCA (factor scores for first component)}

\begin{tabular}{|c|c|c|c|c|c|c|c|c|c|c|c|c|c|c|c|c|}
\hline 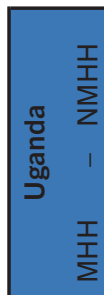 & । & $\begin{array}{l}0 \\
0 \\
0 \\
0 \\
0 \\
0 \\
\\
0 \\
0 \\
0 \\
0 \\
0 \\
0\end{array}$ & । & 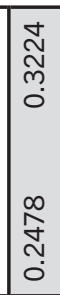 & 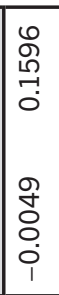 & I & I & 1 & 1 & 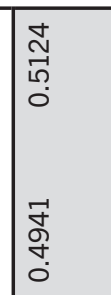 & $\begin{array}{l}\text { } \\
\stackrel{2}{2} \\
\stackrel{2}{\circ} \\
0\end{array}$ & 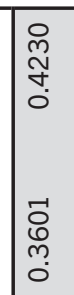 & 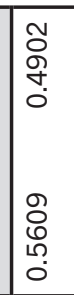 & I & $\begin{array}{l}\vec{w} \\
\stackrel{\sim}{0} \\
\stackrel{\sim}{\sim} \\
\hat{n} \\
\tilde{N} \\
\hat{\sigma} \\
-i\end{array}$ & @ั \\
\hline & 1 & 1 & । & 1 & 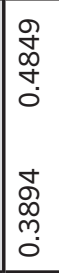 & 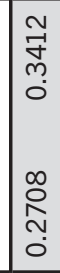 & 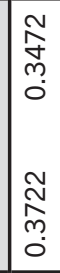 & 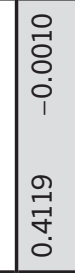 & 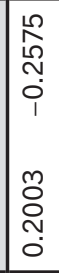 & 1 & 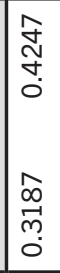 & 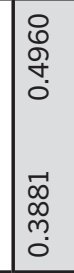 & I & 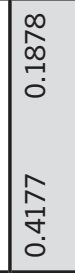 & 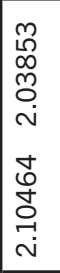 & $\begin{array}{l}\stackrel{\circ}{\circ} \\
\stackrel{\circ}{N} \\
\stackrel{\circ}{\circ} \\
\stackrel{\sim}{\sim}\end{array}$ \\
\hline 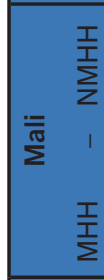 & 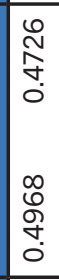 & 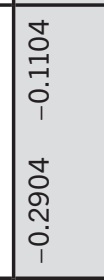 & 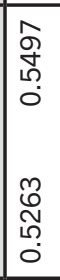 & 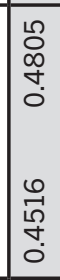 & 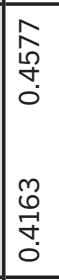 & I & 1 & 1 & 1 & 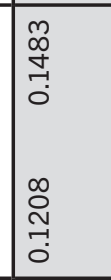 & I & 1 & 1 & 1 & 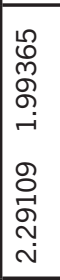 & 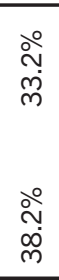 \\
\hline$\sum^{\frac{\pi}{10}}$ & 1 & $\begin{array}{ll}0 & 2 \\
0 & 0 \\
7 & 7 \\
0 & 7 \\
1 & 1 \\
1 & 1\end{array}$ & 1 & 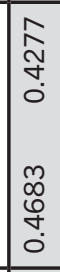 & 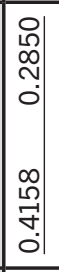 & 1 & I & 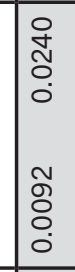 & 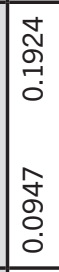 & 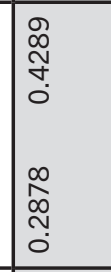 & 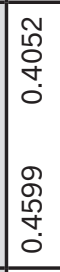 & 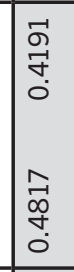 & 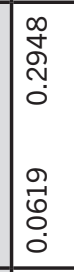 & 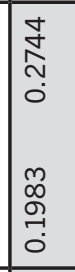 & 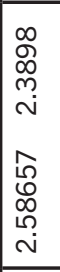 & 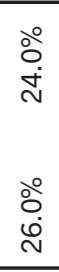 \\
\hline 丞 & 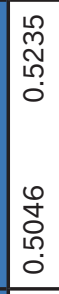 & 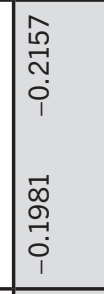 & 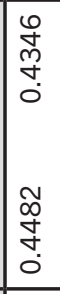 & \begin{tabular}{|l|}
0 \\
$N$ \\
$\stackrel{N}{0}$ \\
0 \\
0 \\
\\
\\
0 \\
0 \\
0 \\
0 \\
\end{tabular} & 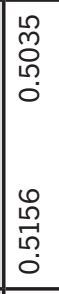 & 1 & 1 & 1 & 1 & 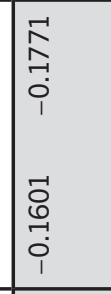 & 1 & 1 & 1 & 1 & 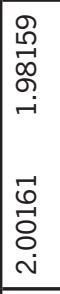 & 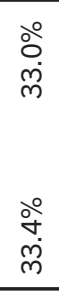 \\
\hline$\frac{\mathrm{I}}{\mathrm{I}}$ & 1 & 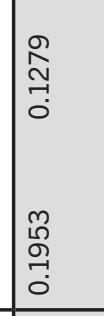 & 1 & $\begin{array}{l}\vec{S} \\
\stackrel{5}{\sim} \\
0\end{array}$ & 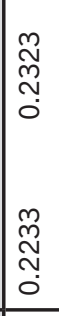 & 1 & 1 & 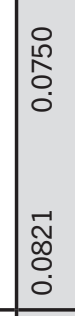 & 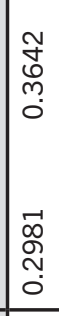 & $\mid \begin{array}{l}\infty \\
0 \\
0 \\
0 \\
0 \\
0 \\
\\
\infty \\
\infty \\
0 \\
0 \\
0 \\
0 \\
0\end{array}$ & 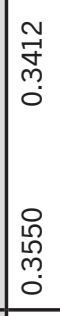 & 1 & \begin{tabular}{|c|}
0 \\
0 \\
0 \\
0 \\
0 \\
\\
\\
0 \\
0 \\
0 \\
0 \\
0 \\
0
\end{tabular} & 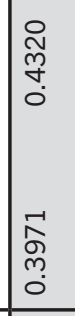 & 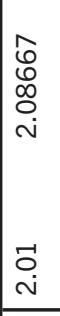 & $\begin{array}{l}\stackrel{\circ}{\sim} \\
\stackrel{N}{N} \\
\stackrel{\circ}{\circ} \\
\stackrel{\sim}{N}\end{array}$ \\
\hline 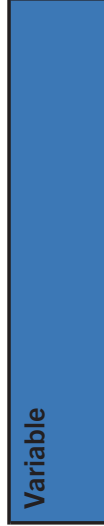 & 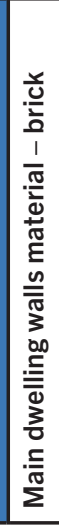 & 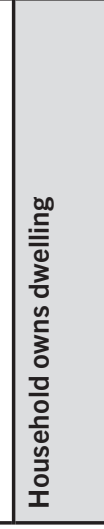 & 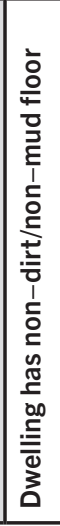 & 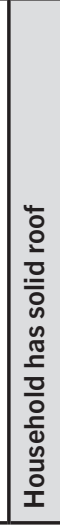 & 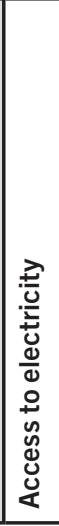 & 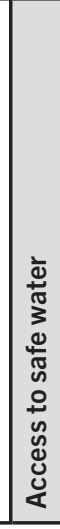 & 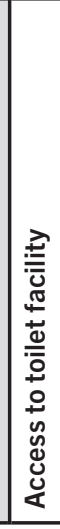 & 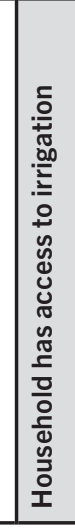 & 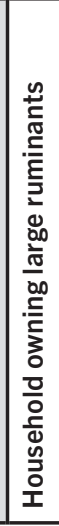 & 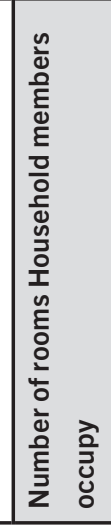 & 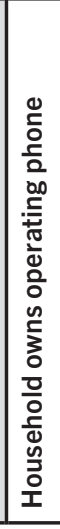 & 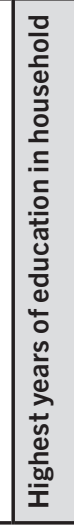 & 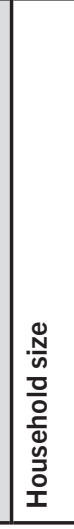 & 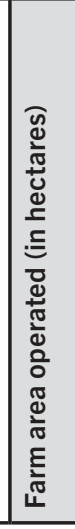 & 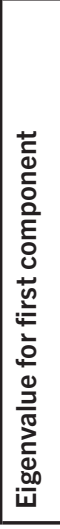 & 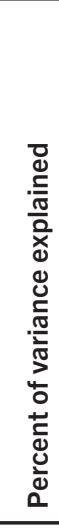 \\
\hline
\end{tabular}





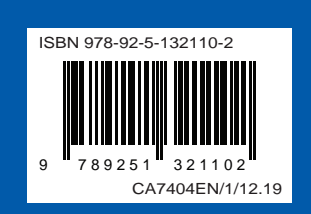

